THE - GEOLOGY

of

EWARARA INTRUSION,

GILES COMPLEX, CENTRAL AUSTRALIA

by

A.D.T. GOODE, B.Sc. and G.W. KRIEG, B.Sc.

\author{
Honours Thesis \\ Department of Geology \\ University of Adelaide. \\ November, 1965.
}




\section{ABSTRACT}

Ewarara Intrusion is a layered ultramafic body which shows the initial stages of a differentiation trend similar to the Mt. Davies Intrusion: It is essentially a flat lopolithic sheet with usually a steep southern contact where the fissures and/or pipes of intrusion are possibly located: It consists of an olivine pyroxenite (Lower Leyer) and a thicker pyroxentte (Upper Layer), together giving a visible stratigraphic thickness of about 500 to 600 feet. There appears to be a marked hiatus between deposition of the layers, possibly due to convectional overtum or, less likely, a fresh influx of magma. Both vertical and horizontal bandings are observed, and are not stmucturally related. They were possibly formed by viscous flow in vertical planes and by gravitational settling respectively. Current action is indicated in some cases by lineated textures. Both chilled and hybrid contacts are observed, the latter being more common. Contamination near the contacts is usual.

Smaller intrusions neer the main body can be represented usually as plagioclaserrich variations of the two main rock types. The first reported occurrence of Giles Complex dykes is noted. An anorthosite body occurs discontinuously along a large shear to the north-west. This shear continues as a crush zone through the main body, dividing it into two lobes.

The metamorphic country rock consists predominantly of gneisses which maintain a reasonably constant attitude. They belong to the pyroxene granulite facies, both orthopyroxene-plagioclase and clinopyroxene-almandine subfacies assemblages being represented. 
Post intrusive dolerite dyke-shear swerms crosscut the whole area. 


\section{$\underline{\text { INDEX }}$}

page

I INTRODUCTION

II EXPERTMENTAL METHODS 4

1. Mineral Separations . . 5

2. Optical Determinations 5

3. Modal Determinations ... . 6

4. Mineral Staining Technique $\quad$.. . ' 6

5. Density Measurements $\quad \therefore$

6. X-ray Diffraction. Techniques . 7

7. Analytical Chemistry. . 8

III. PETROLOGY AND CHEMISTRY 14

A. GILES COMPLEX - 15

Contact Zone . . 15

Olivine Pyroxenite (Lower Layer) 20

Pyroxenite (Upper Layer) 33

Comparison of. Lower and Upper Layers. 37

Mafic Pegmatites. 44

Minor Intrusions . . . 46

1. Gabbroic Dykes . . . 46

2. Small Plug-like Intrusions . : 47

3. Small Lenticular Intrusions 48

4. Anorthosite 49

B. METAMORPHICS ‥ 52

Augen Gneiss. $\quad 52$

Banded Gneiss . 53

Quartz-feldspar Layers . . $\quad 54$

Mylonites . . . 57

Black Granulite " 57

Speckled Granulite 58

Discussion of Metamorphism . 59

C. DOLERITE DYKES 66 


\section{INDEX (cont.)}

IV. STRUCTURE 68

1. Layering ard Folding (Country Rọk) . . . 69

2. Faulting 69

3. Deformation Textures ard their Significance. : 72

4. Other Structural Features (Intrusion) 77

5. Gravity Profile 82

6. Shape of the Intrusions . 85

$\mathrm{V}$ CONCLUSIONS 88

Acknowleđgentents $\quad 92$

References : $\cdot \quad \cdot \quad: \quad 93$ 


\section{IIST OF TABLES}

page

1. Chemical Analyses and Modes

2. Mineral Compositions and Modes

3. Garmet Analyses

\section{APPENDIX VOLUNR}

PLATES
1.- 14
Field Photographs
$.15-.43$
Photomicrographs

FiIGURES
$1-3$
Maps
$(4-27$
Included in text) 
I INTRODUCTION 
The Ewarara Intrusion is conveniently named from Ewarara Creek, the only feature in the locality to bear a name on any published map. The area investigated covers about 8 square miles and is situated in the extreme north-west corner of South Australia only nine miles from the South Australia - Western Australia border and four miles from the South Australia - Northern Territory border (fig. 1). Thus it lies in the Musgrave Park Aboriginal Reserve and remains essentially undeveloped. It is an arid region where vegetation is sparse. Tufty grass or stands of mulga grow on the alluvial plains whilst the stony hill slopes support only the hardy spinifex and a few small bushes. Sizable eucalypts grow in the larger creek beds.

Topography is steep with both the intrusion and country rock risine very sharply some $500 \mathrm{ft}$. above the alluvial plains. The intrusion itself can be pictured as two lobes separated by a shear. The western lobe is elongate in an E.N.E. - W.S.W. direction whilst the smaller eastern lobe runs approximately $E-W$ and parallels the layering of the country rock. Together, these lobes form a long high rounded ridge with a very even sky-line (Flate 1) cut only by one major gorge across the eastern lobe and three smaller gullies, further west, along the north face. The country rock is deeply eroded by a number of creeks which mun generally parallel to the E-W layering, producing a sky-line more rugged then that of the intrusion.

The Ewarara Intrusion forms part of the Giles Complex, a system of basic - ultrabasic layered igneous bodies. Although this basic complex was reported by Basedow as long ago as 1905, this remote region has not yet received close geological investigation, 
but regional maps have been produced by South Western Mining Ltd. and by the South Australian Department of Mines. The latter have published the Mann ( 1 inch to 4 miles) Geological Sheet, 1962 and the Davies ( 1 inch to 1 mile) Geological Sheet, 1964. Recently, R.W. Nesbitt and A.W. Kleeman (1964) published a paper on the Mt. Davies intrusion," a major layered ultrabasic igneous body 10 miles south of Ewarara. Mt. Davies exhibits a petrological and geochemical variation across the layering and shows an uncommonly low ratio of total iron to magnesium. The aim of this project is to elucidate the geology of Ewarara Intrusion with particular emphasis towards its shape and mode of emplacement, the petrologic variations across the body and a comparison of its petrology and structure with that of Mt. Davies.

A total of 3 weeks was spent mapping the intrusion and surroundings in some detail on a scale of 4.2 inches to $1 \mathrm{mile}$ (fig. 2 ). The locality map of samples recorded in the text are shown in fig. 3 . 
II EXPERIMENTAL METHODS 


\section{Mineral Separations}

(a) Crushing

Fresh rook samples were initially crushed to "twenty mesh" grain size in a fly-press, using firstly a wedge-shaped crusher followed by a stainless steel crusher and plate. A manually operated stainless steel pounder and plate were used to further decrease the grain size to between 88 and 120 mesh. Samples were then washed and dried.

\section{(b) Magnetic Separation}

Highly magnetic portions were initially removed by hand magnet. The remaining sample was passed through a Frantz magnetic separator, and by varying the operating conditions of current, side and dip slopes, minerals of different magnetic susceptibilities were isolated. (c) Heavy Liquid Separation

In some cases, exploitation of differences in specific gravity was necessary to achieve separation.

(i) Quartz-potassium feldspar.

A mixture of dimethyl sulphoxide in tetrabromoethane

(approximate S.G. 2.6) in a separating funnel was used to separate these non-magnetic minerals.

(ii) Ortho- and clino-pyroxenes.

Clerici's solution diluted with water (approximate S.G. 3.2) effected in some cases a good separation between pyroxenes.

Hand picking was required in all cases for chemical work.

\section{Optical Determinations}

(a) Optic Axial Angle

A four axis universal stage was used to determine $2 \mathrm{~V}$ of both ortho- 
and clino-pyroxenes.

(b) Refractive Index

$n_{\beta}$ values were determined for both ortho- and clino-pyroxenes. The oil immersion method using sodium light was used with a probable accuracy of \pm 0.002 , in some cases \pm 0.001 .

3. iModal Determinations

Determination of mineralogical modes was carried out by point counting on $\frac{1}{3} \mathrm{~mm}$ steps with traverses $1 \mathrm{~mm}$ apart. Approximately 1000 measurements were made for each thin section.

4. Mineral Staining Techniques

(a) Potassium Feldspar

Polished sections were etched with hydrofluoric acid, and subsequently treated with cobalti-nitrite solution. Potash feldspars were revealed by bright yellow stains.

(b) Calcium-rich Minerals

Applying a modification of Laniz, Stevens and Norman's method (1964) for staining plagioclase, an attempt was made to differentially stain clinopyroxenes ( $\mathrm{Ca} \mathrm{rich}$ ) and orthopyroxenes (Ca poor).

A polished section was etched in hydrofluoric acid, and treated with barium chloride and then amaranth solutions. "Although immersion times were varied, no permanent stain on either pyroxene was observed. Plagioclase stained scarlet.

5. Density Measurements

Fresh rock samples were sawn to approximately $1^{\prime \prime} \times 1^{\prime \prime} \times \frac{1}{2} \prime$ (i.e. 30 grams). These were weighed in air, and also, while suspended, in water and dengities calculated by 


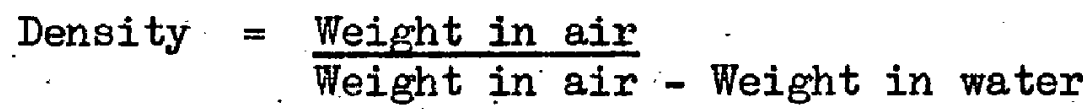

(from Jaeger, 1964)

6. X-ray Diffraction Techniques

(a) Olivine Compositions

Diffractometer traces of smear mounts of olivine powder and zinc oxide (internal standard) on quartz plates were recorded for oscillations between $2 \theta=31.5^{\circ}$ and $33.0^{\circ}$.

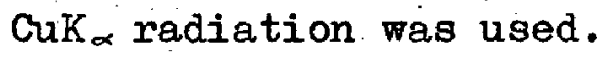

$2 \theta$ (130) for the olivine was accurately measured, and was used to give composition.

(modified from Yoder and Sahama, 1957)

(b) Plagioclase Composition

A similar technique was used to determine plagioclase composition. Oscillation was carried out between $2 \dot{\theta}=31^{\circ}$ to $34^{\circ}$ using cuK radiation, but no internal standard was required.

$2 \theta((1 \overline{3} 1)-(131))$ was measured and used to determine composition. Low temperature state for the plagioclase structure was assumed, and the special graph for thick stratiform mafic intrusions was utilized.

(from Smith and Yoder, 1956)

(c) Garnet Cell Size Determination.

An $11.4 \mathrm{~cm}$ fixed camera and $\mathrm{CuK}_{\alpha}$ radiation were used to record a powder pattem photograph of the sample, and $2 \theta$ values were measured to $0.05^{\circ}$. a! values were determined for high $\theta$ angles, and were extrapolated to $\theta=90^{\circ}$ to give an accurate a cell size dimension. (d) Triclinicity of Potassium Feldspar

A diffractometer trace of a smear mount was recorded between 
29 and $31^{\circ} 2 \theta$ for $\mathrm{CuK}_{\alpha}$ radiation. The separation of (131) and (131) reflections was measured to give triclinicity of the feldspar.

(e) Determination of Or Content of Antiperthite

A standard smear mount of the antiperthite was prepared, and a diffractometer trace was recorded between 20 and $32^{\circ} 2 \theta$ for $\mathrm{CuK}_{\alpha}$ radiation.

$2 \theta((20 \overline{1})$ plagioclase - (20i) potash feldspar) was noted. Heating was carried out at $1000^{\circ} \mathrm{C}$ in an electrical furnace for nine days, by which time homogenisation was completed, and the (201) peaks of both feldspar phases were coincident.

With potassium bromate as an internal standard, a diffractometer trace was recorded between 20 and $22^{\circ} 2 \theta$. The separation of (201) plagioclase and (101) potassium bromate peaks gave the orthoclase content of the antiperthite.

7. Analytical Chemistry

(a) Crushing

300 gms of fresh rock sample was crushed as before (Mineral Separation), with care being taken to avoid contamination and loss of sample. About $75 \mathrm{gms}$ was manually pulverized to less than 120 mesh grain size.

(b) Digestion of Sample

$100 \mathrm{mgm}$ (accurately weighed) of powdered sample was completely reacted with analytically pure hydrofluoric acid and sulphuric acid in platinum crucibles, eveporated to dryness and redissolved in hydrochloric acid. The solution was then diluted to $250 \mathrm{ml}$.

The initial process had to be repeated for samples containing 
spinel. .

(c) Analytical Techniques

(1) E.E.L. Flame Photometer.

Alkalis $\left(\mathrm{Na}_{2} \mathrm{O}, \mathrm{K}_{2} \mathrm{O}\right)$ were measured by spraying samples into a gas-air flame, and comparing the degree of emission with standard samples.

(2) Atomic Absorption Spectrophotometer.

A single beam instrument (Techtron AA3) with modulated lamp source, and the operating conditions shown in fig. 4, was used to determine $\mathrm{Al}_{2} \mathrm{O}_{3}, \Sigma \mathrm{Fe}, \mathrm{MgO}, \mathrm{CaO}$ and $\mathrm{MnO}$ by comparison with. standard solutions. Sample solutions were sprayed in to the gas flames indicated, and percentage trensmissions (and hence absorbances) were measured. The standards used were laboratory chemical solutions and solutions of natural rock standards (various concentrations of W 1 ).

Depending on individual unknown samples, dilutions were sometimes necessary and bumers had to be placed either parallel to or perpendicular to the light path. High temperature burners (Amos and Thomas, 1965) had to be used for nitrous oxide acetylene flames.

Calibration curves obtained for the various elements are shown in figs. 5-9.

The curve for $\mathrm{A}_{2} \mathrm{O}_{3}$ should be treated with some caution as sulphate ions, especially, enhance absorbance. Hence solutions of varying sulphate concentrations will give incorrect relative values. Natural rock standards appeared to give the most 
reliable standard results.

Alkalis also interfere with absorbance of $\mathrm{CaO}$ at low temperatures, but this was overcome by using a high temperature flame. Not comoer. Sirktenent.

\begin{tabular}{|c|c|c|c|c|}
\hline Tube & $\begin{array}{c}\text { Tube Current } \\
(\text { m.A.) }\end{array}$ & $\begin{array}{c}\text { Wavelength } \\
(\mathrm{A})\end{array}$ & $\begin{array}{c}\text { Slit Width } \\
(\mu)\end{array}$ & Flame \\
\hline $\mathrm{Mg}$ & 6 & 2854 & 100 & $\mathrm{~N}_{2} \mathrm{O}-\mathrm{C}_{2} \mathrm{H}_{2}$ \\
$\mathrm{Fg}$ & $\ddots 10$ & 2485 & 35 & $\mathrm{C}_{2} \mathrm{H}_{2}-\mathrm{AIR}_{\mathrm{R}}$ \\
$\mathrm{Al}$ & 15 & 3963.5 & 100 & $\mathrm{~N}_{2} \mathrm{O}-\mathrm{C}_{2} \mathrm{H}_{2}$ \\
$\mathrm{Min}$ & 10 & 2797 & 50 & $\mathrm{C}_{2} \mathrm{H}_{2}-\mathrm{AlR}_{\mathrm{R}}$ \\
$\mathrm{Ca}$ & 10 & 4227 & 50 & $\mathrm{~N}_{2} \mathrm{O}-\mathrm{C}_{2} \mathrm{H}_{2}$ \\
\hline
\end{tabular}

Fig. 4 
Fig. 5

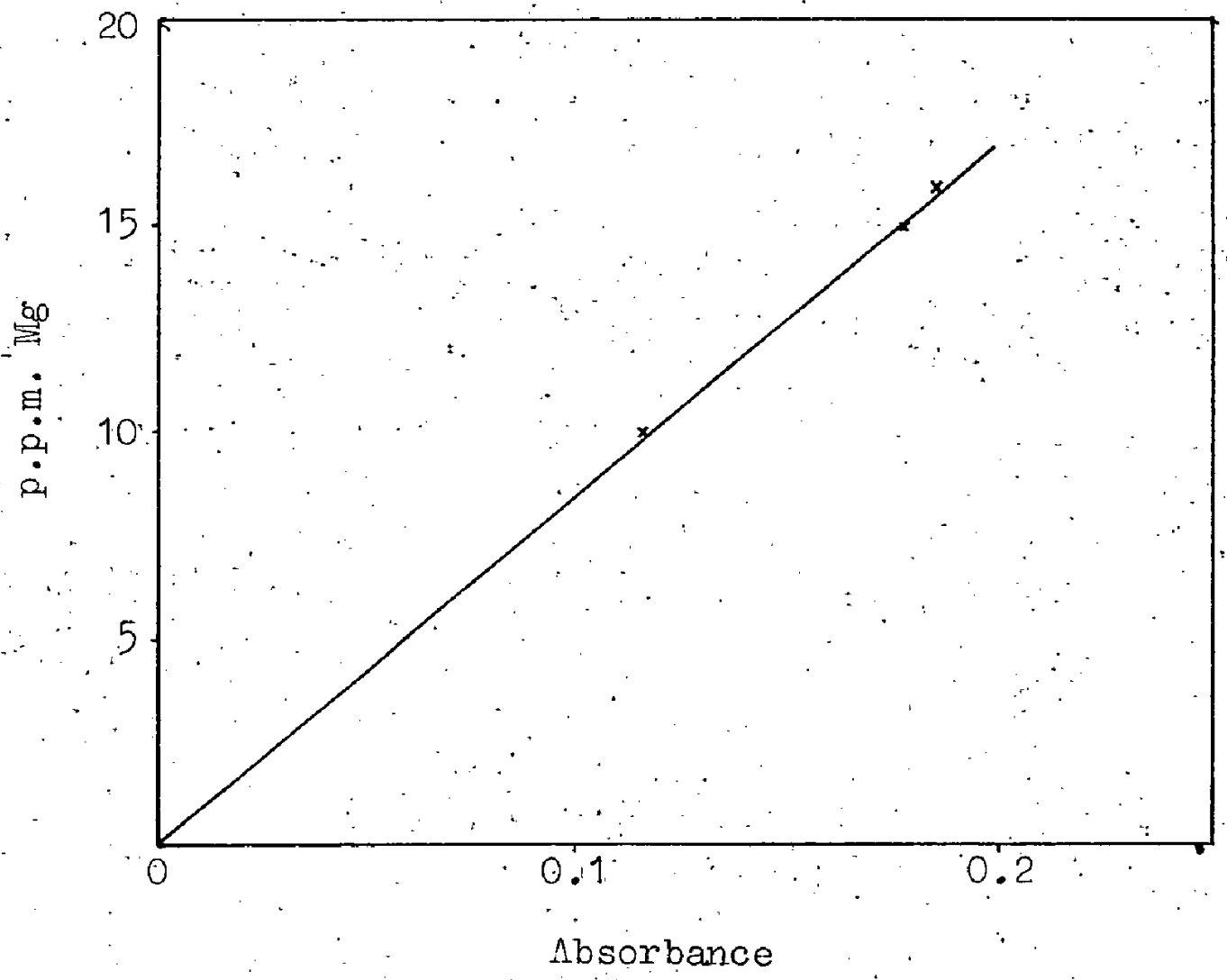

Fig. 6

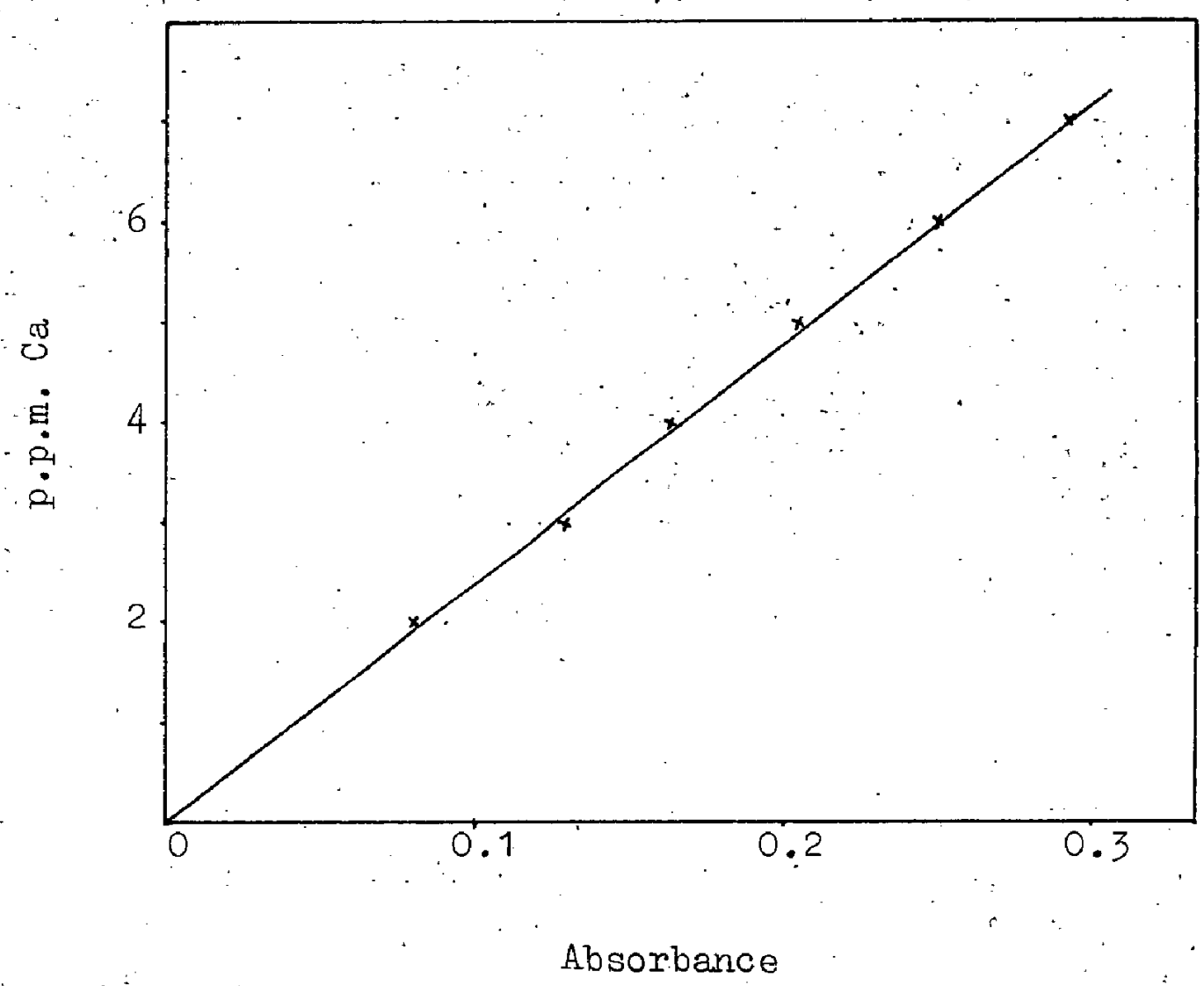


Fig. 7

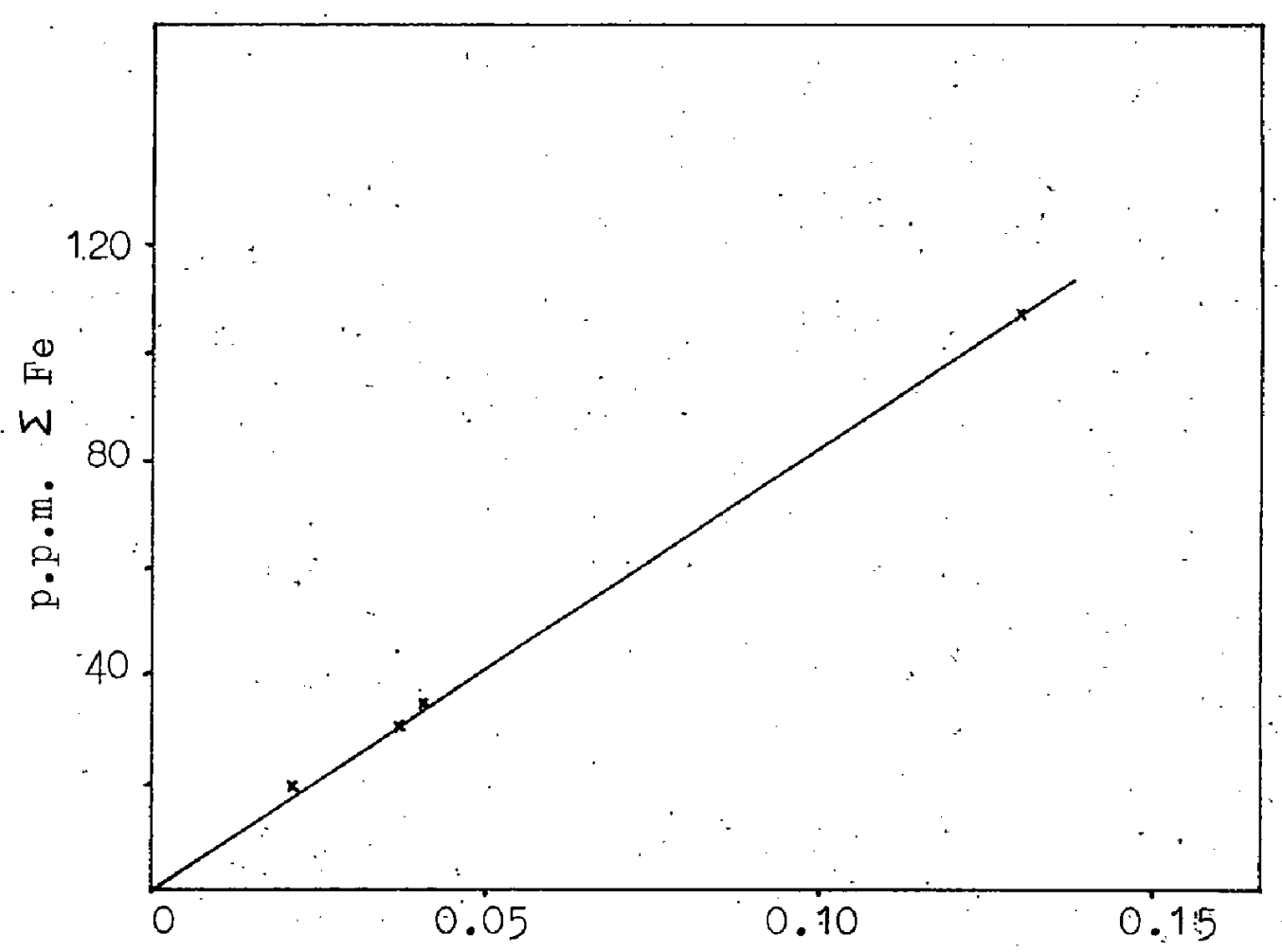

Absorbance

\section{Fig. 8}

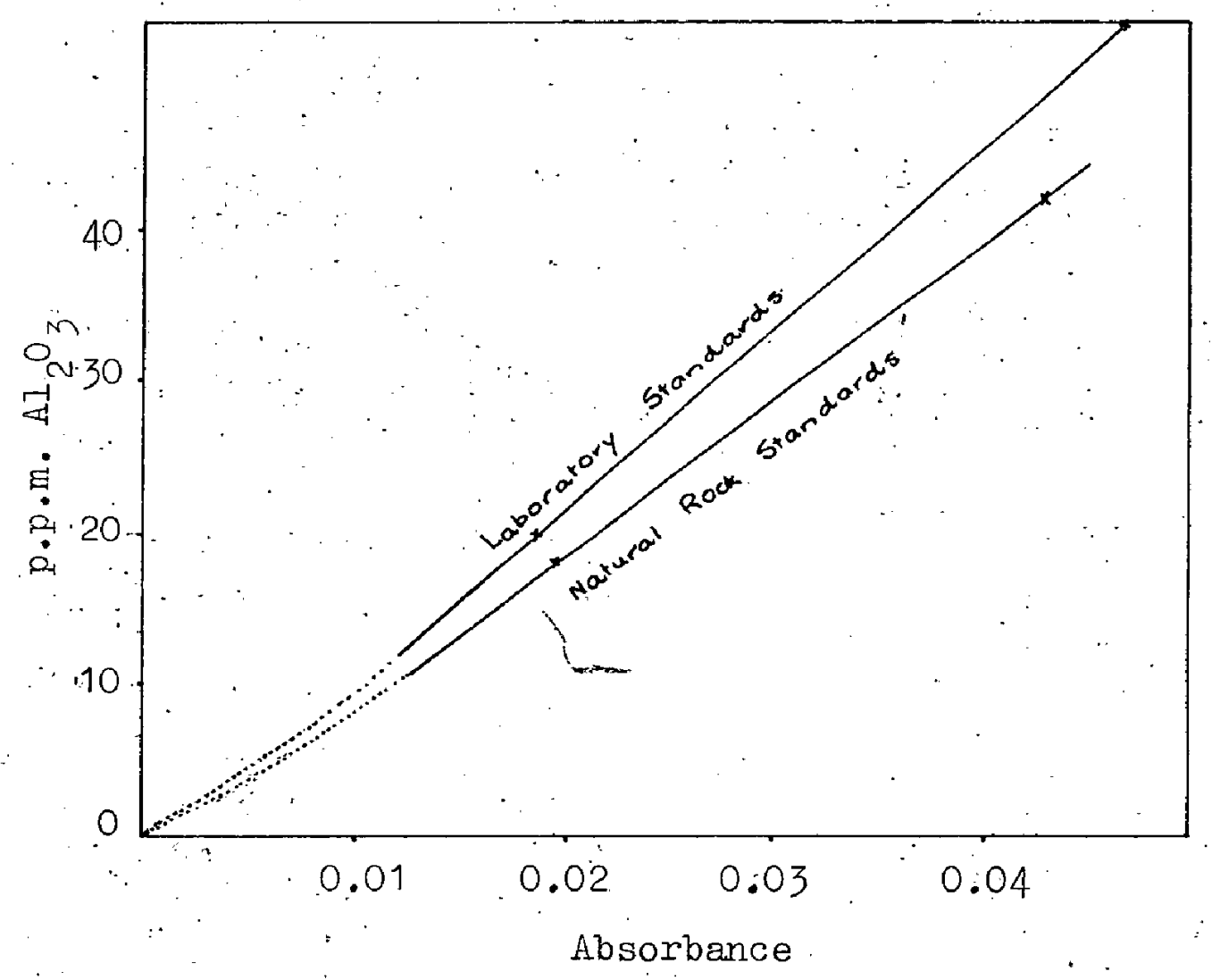


Fig. 9

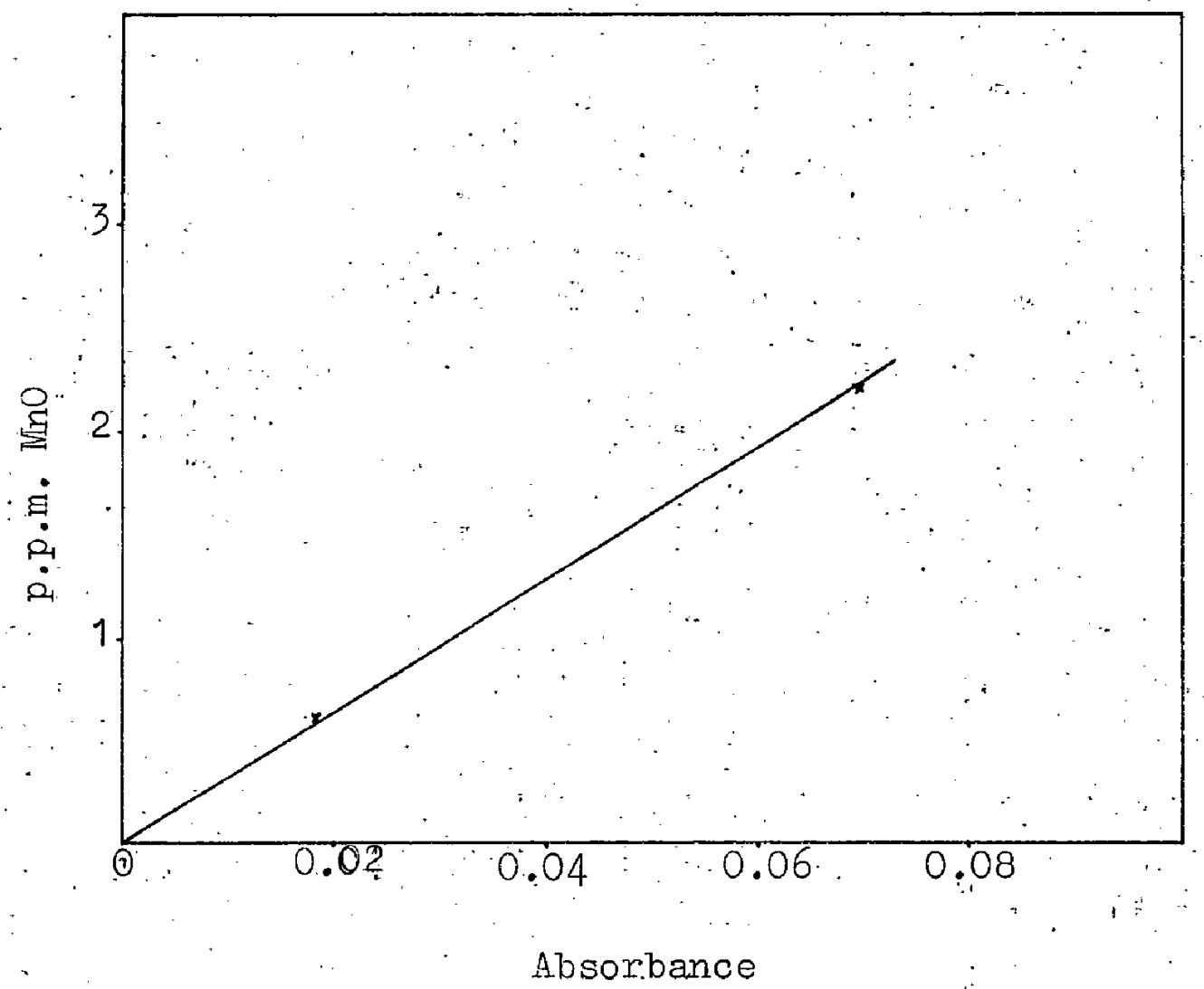


14

III PETROLOGY AND CHEMISTRY 
A. GILES COMPLEX

\section{Contact Zone}

1. Field Relationships

The contact between the intrusive ultramafic rocks and country rock is generally a gradational one, occuring over several feet. However, in some cases, a chilled margin. is observed and in others a sharp irregular contact is very suggestive of progressive: envelopment of the country rock.

Sometimes the actual contact is obscured by a depressed zone of no outcrop, several feet in width. This is especially common in the intertongued area (fig. 22 ).

In all cases it was noted that as the foliated granulites approached the contact, they tended to lose their foliated nature and become much more random in their mineral orientation. In the:most extreme cases they form a coarse grained; "spotty" rock, with a semi-igneous texture. This occurs especially where areas of the granulite are almost surrounded by the intrusive rock $(A 300-17,90)$. It is noticeable in the augen gineiss that the augen remain aloof to this subtle change in texture for longer periods than the remainder of the rock. The augens eventually lose their characteristic form but are still recognisable as; clots near the contact (A300-99a-f). Large crystals of bronzite up to $2^{\prime \prime} \times 2^{\prime \prime}$ are found locally.

2. Petrology

The principal minerals of this zone are orthopyroxene and 
plagioclase, with subsidiary amounts of biotite, hornblende and opaques.

Plagioclase is usually interstitial although ragged laths form in the chilled contacts or sharp digestive contacts. Plagioclase from the chilled contact analysed by $X$-ray methods gave a composition of An $67.5^{\circ}$ Commonly, although not in the chilled contact or in the sharp digestive contacts, the plagioclase is poikilitic.

Pyroxene is usually found as a granulated mosaic, al though some phenocrysts are observed.

(a) Chilled Margin (A301-1, A300-30)

The transition from country rock to the chilled zone of the intruding magma. is marked by

(1) a decrease in grain size;

(2) the sudden appearance of red flakes of biotite (not necessarily at the exact contact);

(3) the decrease in amount of plagioclase relative to pyroxene;

(4) the formation of ragged plagioclase laths, sometimes perpendicular to the contact;

(5) quite intense fracturing parallel to the contact.

The grain sizes of pyroxene phenocrysts increase from about $1 / 2 \mathrm{~mm}$ near the contact to $2 \% / 2-3 \mathrm{~mm}$ about $10 \mathrm{~cm}$ from the contact. Red biotite occurs as a subsidiary constituent in a zone a few centimetres wide near the contact, but further from the contact brown pleochroic hornblende forms in preference. 
(b) Sharp Irregular Contact. (A300-83)

The intrusive material appears in this contact to be enveloping the augen gneiss of the country rock.

The mafic material consists of fine grained pyroxene (often coated by a dark iron rich material) interstitial to ragged plagioclase laths. Magnetic opaques are also present. The plagioclase is often arranged in radiating groups. Fine and coarser grained clumps occur together, although the grain size in general tends to become coarser further from the contact $(0.4$ to $1 \mathrm{~mm})$. Most of the material is stanned a red brown, but isolated patches are not. A brown ferruginous rim about $2 \mathrm{~mm}$ wide is characteristic of the margin. This rim is notably absent where the mafic material is in contact with the ferromagnesian-poor augens of theccountry rock.

Near the contact, coarse grained clumps of pyroxene and plagioclase $(0.5 \mathrm{~mm})$ occur in the mafic material and probably represent enveloped augens in the process of digestion by the magma.

Plagioclase analysed by $\mathrm{X}$-ray methods gave a composition of $\operatorname{An}_{62}$

In the country rock, plagioclase and orthoclase grains appear to be undergoing a.metasomatic (?) replacement. Orthoclase grains have a: mottled appearance and plagioclases show characteristic fernlike intergrowths, which appear to be altered polysynthetic twinning. 
(c) Gradational (Hybrid) Contact (A300-11)

These, the commonest contacts, show no sharp physical break between country rock and intrusive rocks (Plate.12).

In thin section, the contact is marked by

(1) the sudden appearance of red biotite;

(2) a sharp increase in amount of pyroxene relative to plagioclase;

(3) fracturing parallel to the contact. :

Iike the chilled margin, fracturing is localised in a zone about.1/2" to $1 "$ across.

The plagioclase is anhedral and equigranular, with a marked tendency to be poikilitic.

The orthopyroxene is pleochroic and optically negative (probably bronzite or hypersthene).

3. Evidence of Contamination

The most obvious field evidence of progressive active envelopment of country rock by the: magma is exhibited by A300-83

Xenolithic material not digested by the magma is exhibited by A300-109.(Plate 11) and is also seen near A300-77. Both are found near intrusive contacts. Thin lenticles of felsic material (mainly feldspar) are incorporated in a fine grained mafic material. Homogenisation of these fragments by. the magma has not been completed.

A300-33 contains a lenticular raft about $5 \mathrm{~cm}$ Iong, made up of granulated pyroxene grains $(0.2 \mathrm{~mm})$, some larger pyroxenes 
$(0.5 \mathrm{~mm})$ and a little plagioclase. With a typical cataclastic texture, it has a gradational boundary with the coarser pyroxenite in which it is found. Its shape and foreign appearance make it appear to be either a xenolith of country rock or possibly of part of a fragmented chilled margin of the body.

Contamination may also be shown by the distribution of biotite in the body. It occurs at its maximum concentration near the contacts, sometimes forming several percent of the rocks, and although reasonably common throughout the lower layer, becomes much less so towards the top of the upper layer. 4. Evidence of Hydrous Conditions

Despite the presence of biotite, the inner portions of the intrusion appear to have formed in essentially anhydrous conditions. However hornblende is very common in most of the smaller bodies and at the margins of the main intrusion. It appears to be of a secondary nature, replacing the bronzite (Plate 24). Thin blades of opaque material similar to those in the bronzites occur as oriented intergrowths in the hornblende, and may be remnant from the pyroxene. It can be quite coarse grained, sometimes making up 10 to $15 \%$ of the rock. Hornblende also occurs in the chilled margins.

In the hand specimen, hornblende often forms as large, black shiny tabular crystals (A251 - N247).

The presence of this hornblende indicates hydrous conditions at some parts of the contact. 
5. Poikilitic Plagioclase

Plagioclases in the hybrid zone are often poikilitic (Plate 16) - containing subhedral to rounded, often elongate, grains $(0.06 \mathrm{~mm}$ to $0.2 \mathrm{~mm}$ long) of pyroxene. These grains are approximately aligned parallel to the albite twin plane. At an extinction position, an undulose extinction halo is often observed around the inclusions.

This phenomenon is also observed in some plagioclases in the country rock near the contact (Plate 15). In some cases the pyroxene inclusions assume a euhedral form very similar to those of the needle inclusions in plagioclase in the olivine pyroxenite.

\section{Olivine Pyroxenite (Lower Layer)}

1. Fieid Relationships

The olivine pyroxenites are characteristically dark, massive and coarse grained. A thin iron oxide stain coats the weathered surfaces, which are rough and reflect the coarse nature of the rock. The pyroxenes often stand out from the surface and characteristically the pyroxenes show a chatoyant or silky lustre.

The olivine pyroxenite which formsthe lower layer of the main pluton is not in continuous outcrop around the margin. It is absent along the south-eastern contact, where the contact appears to be steeper and of a different nature to the intrusive contact of the northern and western sides. Owing to steep scree slopes, the olivine pyroxenite can only be observed as 
discontinuous outcrops al ong the north-western margin of the body. Outcrops also occur in the southern alluvial plain, and a small plug (A300-77) is found to the west of the body. Banding is observed in some areas.

\section{Petrology}

The constituent minerals are bronzite, olivine, plagioclase spinel, opaques (mainly ilmenite), biotite with small amounts of clinopyroxene.

A more specific name for the rock could be olivine bronzitite:

\section{(a) Mineral Descriptions \\ Bronzite.}

Bronzite is generally. the major component in the rock, reaching $50-70 \%$ of it in most cases, although in some rocks (A300-84) it can become as low as 10\%. Most of the anomalouisly low percentages occur in small bosses anda suchlike,

The bronzites tend to be subhedral to euhedral, with always some tendency to crystal development.

Grain size varies from about $1 \mathrm{~mm}$ to $5 \mathrm{~mm}$, with the majority being $1.5 \mathrm{~mm}$ to $3 \mathrm{~mm}$ in diameter.

\section{(i) Optical Properties}

In thin section a strong pleochroism is exhibited (usually more indicative of hypersthene than bronzite). The pleichroic

$$
\text { scheme is: } \quad \begin{aligned}
\mathrm{X} & =\text { apple green } \\
\mathrm{Y} & =\text { Iight pink } \\
\mathrm{Z} & =\text { apple green }
\end{aligned}
$$


For $\dot{A} 300-127,2 V_{2}=88^{\circ}$ and $n_{\beta}=1.672$ were determined (Table 2 ), and indicated compositions of $\mathrm{En}_{88}$ and $E n_{89}$ respectively (Hess, 1952).

\section{(ii) Hourglass Zoning (and exsolution)}

A characteristic feature of the bronzites is the remarkable zoning they exhibit. In its most perfect. form, the zoning has the shape of an hourglass (Plate 30). However, generally the zoning is much less well developed.

On close examination, very small (5-10 $\mu$ long) light green needle like exsolutions are seen to be massed and aligned in. the orthopyroxene (Plate 19), the degree of massing determining the zoning.

In view of their shape, it is unlikely that the zoning has been formed by the usual crystal growth method.

The exsolutions are generally subhedral and have been aligned in $\{010\}$ of the orthopyroxene, approximately parallel to c. This alignment, coupled with subsequent deformation of the crystal, is thought to give rise to the chatoyant or silky effect so aesthetically pleasing in the hand speciment

Apart from the hourglass and chemical zoning, the areas of growth appear to have been controlled by other factors as well. It is noticeable in many grains that towards their boundary the exsolutions become coarser $(10 \mu x 3 \mu)$, scarcer in number, less elongate and more anhedral. On the actual boundaries, one often observes concentrations of anhedral brown-green spinels (about $10 \mu \times 5 \mu$, and up to $70 \mu \times 5 \mu$ ) which 
Fig. 10

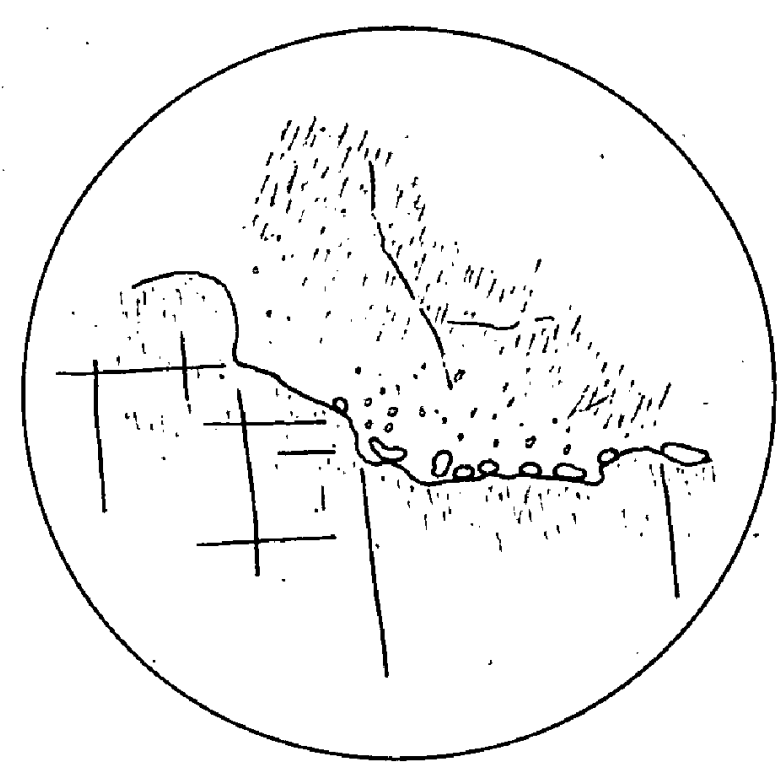

a

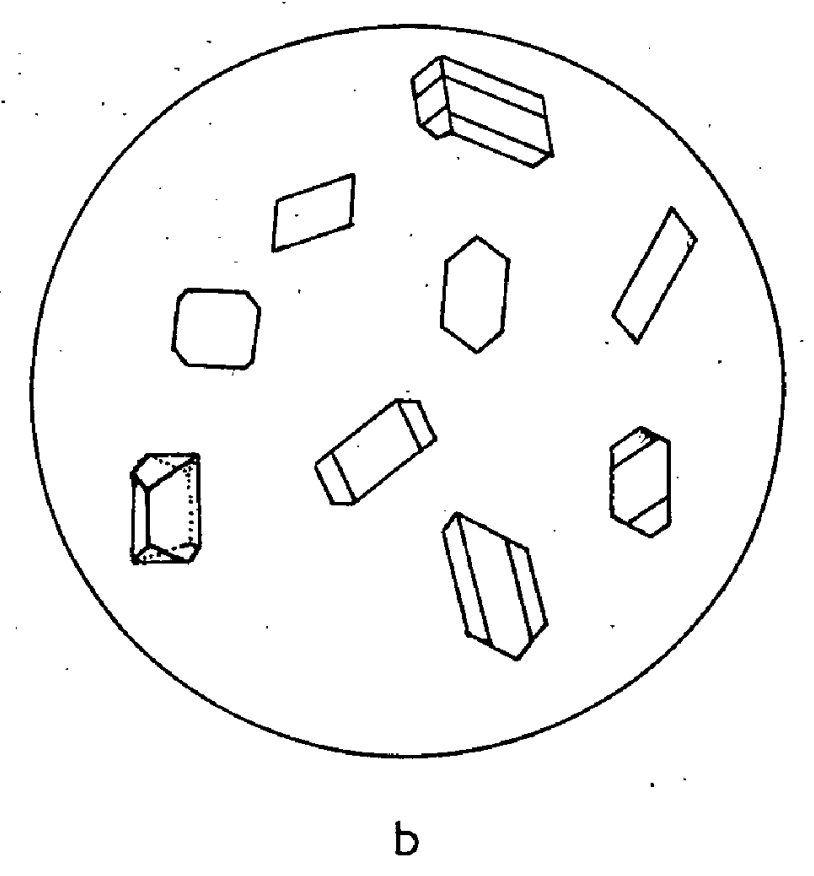


appear identical except in size to the coarser exsolutions (fig. 10a). This suggests that the exsolutions in the bronzite are spinel.

In 300-127; a smoky bronzite was observed enclosing an olivine, with a colourless bronzite rim between the two (fig.lla This rim is in optical continuity with the outer smoky bronzite. The needle exsolutions of the smoky bronzite tend to coarsen and become more granular at the junction with the colourless rim.

Spinels are also sometimes concentrated on pyroxene cleavages.

(iii) . Normal Zoning

Distinct from the hourglass zoning mentioned above, classical zoning presumably reflecting chemical variations also occurs. (Plate 29). Although compositional variations of the host mineral may occur, the zoning is physically distinguished by degree of spinel (?) exsolution.

(iv) Clinopyroxene Exsolution

Irregular patches of clinopyroxene as well as spinel are exsolved from the bronzites. It is noticeable that the two types of exsolution do not usually grow together, although in some cases granular spinels are found on the boundary of the clinopyroxene exsolution.

In A300-84, a large bronzite shows several sets of exsolution on $\{100\}$ aligned on irrational planes. The most prominent are irregular coarse lamellae (0.06 to $0.1 \mathrm{~mm}$ long) 
Fig. 11
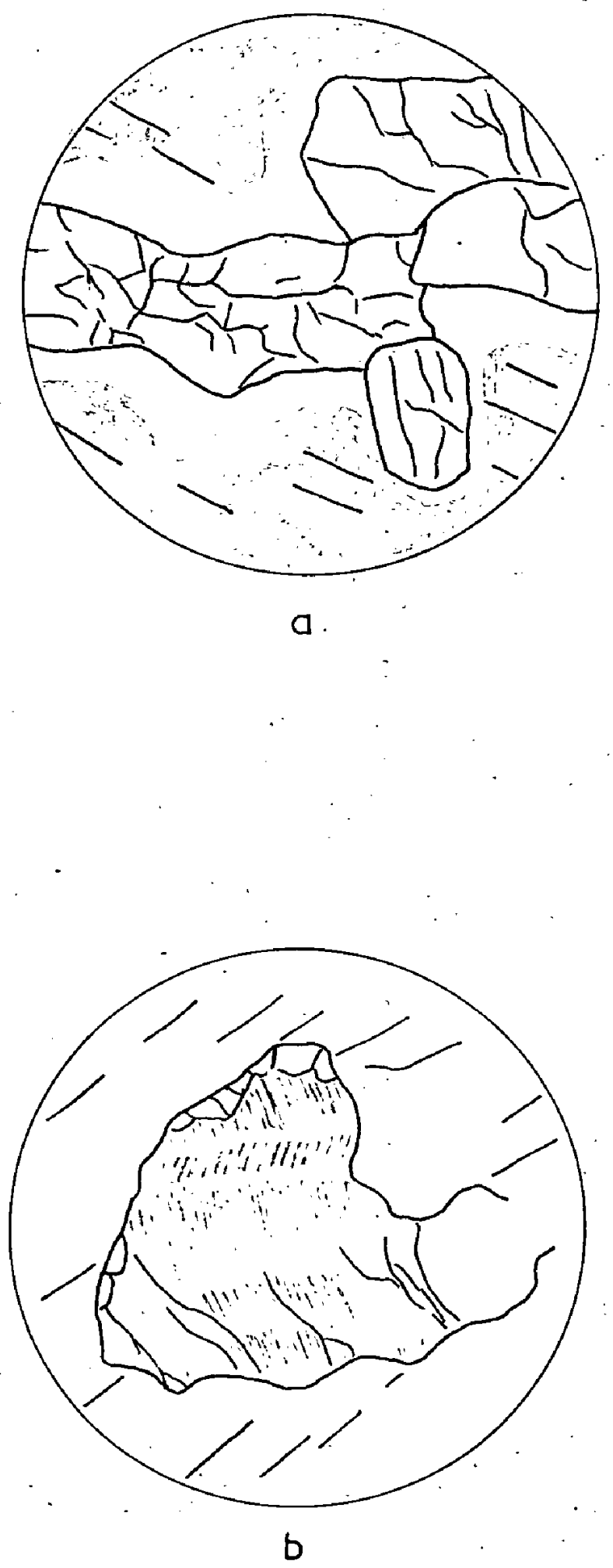
of clinopyroxene. Also very present were two crossed sets of fine dark needles ( 0.01 to $0.02 \mathrm{~mm}$ long) and a very fine lamellar schiller exsolution. The needles only occur near the edges of the grain. No evidence was observed to suggest that the bronzites were in fact inverted pigeonites (Brown, 1957 ). (v) Kink Banding

Kink banding is often observed in bronzites (Plate 31,32 . A geometrical discussion of these are given in IV, structure. Occasionally kinked bronzites are observed as inclusions in undeformed smoky bronzite, (fig. $11 b)$. It is probable that the kinking occurred after inclusion, rather than before it.

\section{Olivine.}

In general the olirvine constitutes between 10 and $40 \%$ of the rock, although in some cases $60-70 \%$ is observed.

The olivine usually occurs as rounded euhedral grains between. 1 and $4 \mathrm{~mm}$ in diameter; $10 \mathrm{~mm}$ crystals were observed occasionally. It forms both as discrete grains and as aggregates. Aggregation may be caused by physical attractive forces (interfacial tension) in a liquid medium (Voll, 1960).

It is very often rimmed by later bronzites.

Intergrowthe of thin opaque blades is observed commonly (Plate 21). These are oriented parallel to $[001]$ and. approximately in $\{100\}$ of the host. They are up to $0.4 \mathrm{~mm}$ long and $0.03 \mathrm{~mm}$ wide.

Undulatory banding (or kink banding) was observed quite commonly (Plate 34). One olivine grain in a kinked bronzite 
appeared to inherit the kinking to some extent.

$X$-ray determinations gave compositions of $F_{85} .5$ and $F o_{88}$ for $A 300-91$ and $A 300-127$ respectively.

Plagioclase.

Plagioclase is interstitial to the bronzite and olivine, generally forming about $5-10 \%$ of the rock, although in some cases an abundance of up to $30 \%$ is observed. The interstitial areas rarely exceed $5 \mathrm{~mm}$ in diameter.

The plagioclases are optically negative with $2 \mathrm{Vx}=80^{\circ}$. Often untwinned or showing deformational features (e.g. glide twinning), the plagioclase at best only exhibits poorly developed twinning and cleavage making it difficult to make accurate compositional determinations by extinction angle methods. However approximate compositions varied from An 28 to $\mathrm{An}_{38}$, the majority falling at about $\mathrm{An}_{32}$. Owing to the limitations of the calibration graph (Smith and Yoder, 1956), a compositiónal value for $A 300-127$ by $X$-ray diffraction means could not becobtained. However the composition must be less than $A_{40}$, and probably nearer $\mathrm{An}_{30}$ (Table 2).

\section{(i) Inclusions}

Similar to the bronzites, the plagioclases are remarkable for the massed inclusions they possess (Plate 17). These inclusions are a pale green colour, and cause the hand specimen plagioclase to' exhibit a blue-green colour. The inclusions are usually euhedral and vary from about 10 to $30 \mu$ in length and and up to about $5 \mu$ in width. Some needles up to $12 q u$ long are 
observed. They vary in shape from stubby to needlelike crystals. The degree of massing varies, but in rare cases they can make up to $25 \%$ or more of the plagioclase.

The inclusions appear to be crystallographically oriented in one direction with differential growth in two other directions giving a tri-orientation ( fig. 12 ).
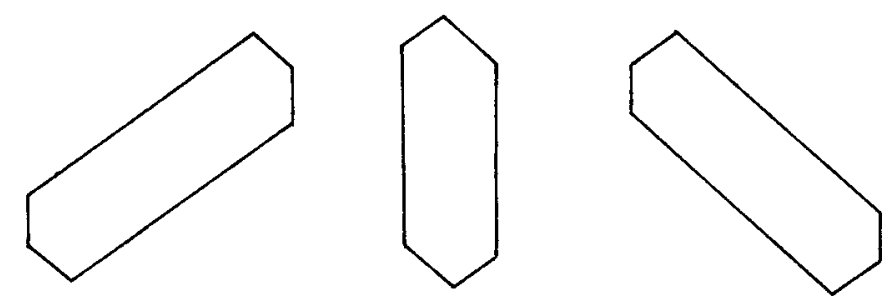

Fig. 12

The most prominent of these directions is parallel to the albite twin lamellae - sometimes certain twins seem to be enriched in the number of inclusions to the detriment of the adjacent ones. The size of the inclusions made it impossible for optical or accurate crystallographic measurements to be made, making identification difficult. Common cross-sections are shown in fig. 10b. Rhombic sections form the most common basic section. A grain showing simple twinning was observed once, as was an octagonal (?) section. Identification was tentatively suggested as a pyroxene. Further indirect evidence will be discussed later in this section.

\section{Clinopyroxene.}

Small anhedral grains $(0.2$ to $0.4 \mathrm{~mm})$ of a monoclinic pyroxene are fairly common in the finer groundmass surrounding 
the bronzite-olivine phenocrysts. They are light green, non pleochroic and possess a moderate birefringence.

$$
\begin{aligned}
& 2 \mathrm{~V}_{\mathrm{z}} \simeq 60 \\
& n_{\beta}=1.680 \pm .001 .
\end{aligned}
$$

This gives an approximate composition of diopsidic augite. Spinel.

Green to brownish green isotropic anhedra (up to $0.5 \mathrm{~mm}$ ) are quite common (about 3\%) in the olivine pyroxenite. It is frequently found as inclusions in opaques. In some cases it forms a skeletal intergrowth with bronzite.

Spinel is also thought to occur as exsolution in the bronzite.

\section{Biotite.}

Anhedral biotite grains, ranging in size from tiny flakes up to $1 \mathrm{~mm}$ in diameter, may constitute up to $5 \%$ of the rock. It is closely associated with opaques, and commonly occurs near olivine, spinel or bronzite.

It possesses a very characteristic pleochroic scheme

$$
\begin{aligned}
& \mathrm{X}=\text { straw yellow-brown } \\
& Y=\text { red brown } \\
& \mathrm{Z}=\text { red brown }
\end{aligned}
$$

Fine opaque needles smaller than $10 \mu$ in length sometimes occur on $\{001\}$.

\section{Opaques.}

A polished section (A300-84) was studied and showed a predominance of ilmenite with lesser amounts of magnetite and 
sulphide minerals.

(i) Ilmenite.

Ilmenite is asually granular, up to $1 \mathrm{~mm}$ in diameter, but generally about $0.5 \times 0.5 \mathrm{~mm}$. It also exhibits twinning.

(ii) Granular intergrowths are common between pyriteilmenite; pyrite-chalcopyrite; magnetite-ilmenite; pyrrhotite-chalcopyrite. These are generally between 0.1 and $0.5 \mathrm{~mm}$ in diameter. No nickel minerals were observed.

Fine grained ilmenite and pyrite also occur sometimes in the cleavages of the pyroxenes.

Ilmenite sometimes forms graphic intergrowths with silicates.

(b) Textural Relationships

Approximately euhedral bronzite and rounded crystals of olivine form the main primary precipitate of the olivine pyroxenite. There is no apparent alignment visible in thin section.

The interprecipitate material mainly consists of poikilitic plagioclase and small grains of clinopyroxene. Biotite and opaques are also present.

Spinel appears to form in the primary phase.

The original textural relations are often somewhat confused by post-crystallizational cataclisation.

(i) Primary Precipitate

Olivine and spinel appear to have been the initial 
precipitates of the magma. Olivine usually exhibits rounded edges which may represent resorption prior to deposition owing to slight changes of temperature or pressure, or other factors (Jackson, 1961).

The olivine probably formed the nuclei for later crystallization of the bronzite, as rimming of the olivines is very common. ${ }^{*}$ The last formed bronzites assume a smoky colour. Spinel occurs as inclusions in both olivine and bronzite. (ii) Interstitial Material

Plagioclase is the major interprecipitant. Because of its unusually albitic nature, it characteristically forms reaction rims about $0.2 \mathrm{~mm}$ in width around exposed olivines (Plate 25) and rarely around bronzite (Plate 26).

These coronal rims on olivine have an inner zone of colourless orthopyroxene, which is surrounded by a symplectic intergrowth of spinel and an unknown colourless mineral. The vermicular spinel can occasionally be seen to "emanate" from large crystals of spinel located at the boundary (Plate 20). Biotite also appears to be a secondary material, intimately associated with opaques and it may be that most of the observed opaques formed similarly. The biotite and opaques tend to form where the plagioclase comes in contact with olivine, spinel or bronzite (e.g. A300-77, where biotite rims the orthopyroxene). Possibly in A300-84 biotite and opaques tend to form in the more confined interstitial areas in preference to the larger interstices. 
Neither the coronal rims nor the occurrence of biotiteopaques are fully. understood.

Clinopyroxene forms as small anhedral grains in the groundmass andappears to have precipitated in the interstices. Secondary enlargement of the bronzite grains has occurred where settled crystals have continued to grow from the interprecipitate liquid after deposition. These rims (Plate 27) are in optical continuity with the primary grains, but do not contain the massed needle exsolutions. Hence the environments of formation of both parts of the bronzites were probably chemically as well as physically distinct from one another. Spinels commonly concentrate on the boundary zone between the two parts, and sometimes penetrate the secondary rim as vermicular intergrowths (Plate 28).

Various deformational features, such as undulose extinction kink banding and other granulation features are observed in certain minerals, and are described in Section IV.

(iii) Significance of Inclusions in Plagioclase

A possible gradation can be observed between the small inclusions in plagioclase in the metamorphic rocks near the contact and in the olivine pyroxenite (and mafic pegmatite). The contact zone shows an intermediate stage (Plates 15, 16, 17). The inclusions tend to become finer grained and more euhedral from the plagioclase in the metamorphic rocks to the plagioclase of the olivine pyroxenite. The inclusions are of 
similar colour and shape, and appear to be of the same material, possibly clinopyroxene.

Possibly the inclusions became incorporated in the plagioclase in the metamorphic case during a highly plastic state of the rock during contact metamorphism by the intrusion. In the igneous case, it appears as though clinopyroxene was precipitated jointly with plagioclase in the interstitial areas of the olivine pyroxenite, and became subsequently oriented after incorporation in the plagioclase.

The lesser degree of alignment and crystal form in the metamorphic and contact rocks could be due to lower temperatures and lesser mobility, shorter times at high temperatures and hence less freedom for growth.

(iv) Significance of "Tip Heaps"

Several small black nobbly outcrops (Plates 2,9) of olivine pyroxenite (A251-N251) occur near the southern alluvial plain. These appear to have no petrological or structural significance, and are probably due to unusual geomorphological processes. Evidence from other areas (e.g. Blackstone Range) suggests that an initial cliff gradually broke away on its other side to leave a small steep "dump" of rocks. These sometimes retain their initial jointing pattern. Weathering solutions were deposited on these rocks to give the external characteristic dark black colour.

Pyroxenite (Upper Layer)

1. Field Relationships 
The upper layer is a medium grained pyroxenite with a characteristically dark colour and granular texture. It occurs stratigraphically above the olivine pyroxenite. The pyroxenes are readily distinguishable in the hand specimen, tending to pepper the weathered surface, and exhibit a waxy lustre and prominent cleavage when broken. The weathered rocks cover the ground as dark coloured tabular slabs, the dark colour resulting from a thin stain coating.

Good igneous banding is observed in certain horizons.

\section{Petrology}

\section{(a) Mineral Descriptions}

The dominant minerals are bronzite and augite, with minor plagioclase and traces of biotite and opaques. Olivine has not been observed in this layer (with the exception of A300-132, a layered specimen near the southern contact of the western lobe).

\section{Bronzite.}

Bronzite appears to constitute about $50-60 \%$ of the rock (although it is difficult to distinguish from augite). The grains are subhedral to euhedral and commonly range from 1 to $2 \mathrm{~mm}$ in diameter, although some grains are as large as $5 \mathrm{~mm}$.

(i) Optical Properties

Small and possibly systematic variations are observed in refractive index and $2 \mathrm{~V}$ in the upper layer.

$$
\begin{aligned}
2 V_{x} & =86-90^{\circ} \text { (camp traverse) } \\
n_{\beta} & =1.680 \text { to } 1.683 \text { (tip heap traverse) }
\end{aligned}
$$

These correspond to compositions of $\mathrm{En}_{85-87}$ and $\mathrm{En}_{82-84}$ 
respectively (Hess

A strong pleochroism similar to that of bronzites in the lower layer is observed.

\section{(ii) Exsolution}

Clinopyroxene is exsolved on $\{010\}$ as small elongate blebs. Augite.

Augite constitutes approximately $30-40 \%$ of the pyroxenite. Some euhedral to subhedral phenocrysts are observed, but commonly the augite has been granulated to form a fine grained matrix.

Simple twinning with $\{100\}$ as twin plane is common but multiple twinning is not observed.

Kinking is less common than in the bronzite.

(i) Optical Properties

It is pale green and non pleochroic.

$$
\begin{aligned}
2 V_{z} & =60^{\circ} \\
n_{\beta} & =1.688
\end{aligned}
$$

This gives a composition of $\mathrm{En}_{38} \mathrm{Fs}_{12} \mathrm{Wo}_{50}$ for augite in A300-116.

(ii) Exsolution

Exsolution of small blebs of orthopyroxene on $\{100\}$ is common. Irregular pleochroic patches of orthopyroxene up to $0.5 \mathrm{~mm}$ in diameter are sometimes observed. Occasionally rectangular schiller exsolution occurs.

\section{Plagioclase.}

Plagioclase occurs as anhedra, interstitial to the pyroxene. Composition varies randomly throughout the upper layer, from 
approximately $\mathrm{An}_{60}$ to $\mathrm{An}_{45^{\circ}}$, A300-116 gave a composition of An $_{62}$ by X-ray methods. Antiperthite exsolutions are observed in some grains. Plagioclase constitutes between $8 \%$ and $0.5 \%$ of the pyroxenite. (Table 2).

\section{Biotite.}

Nearly all thin sections examined showed traces of biotite present. When present these often occurred as plates rimming pyroxene in contact with plagioclase.

(b) Textural Relations

In most thin sections, the bronzite and augite crystals (1-2 $\mathrm{mm})$ have been granulated to a fine grained $(0.1$ to $0.2 \mathrm{~mm})$ mosaic of equant grains.

Grain size increases noticeably from north to south across the eastern lobe, and the western lobe also displays an increase in grain size of $1 \mathrm{~mm}$ up to $4-5 \mathrm{~mm}$ in pyroxenes from the base to the observed top of the upper layer. Granulation of the pyroxenes sometimes overshadows this variation.

The southern margin of the eastern lobe isiamajor crush zone. Although previously regarded as a dolerite dyke (Davies Sheet, S.A. Dept. of Mines, 1964), its mineralogy and texture are distinctly similar to other pyroxenite specimens, despite its coarser nature $(5-10 \mathrm{~mm})$ and predominance of augite over bronzite. The coarser texture is in keeping with the north to south increase in grain size, and the different proportions of pyroxenes is possibly an expression of the crystallization history of the magma. 
In the south-western corner of the main intrusion a pyroxenite occurs in close proximity to the olivine pyroxenite (the actual contact is marked by a zone of no outcrop). The mineralogy and texture of this rock (A300-81a) is very similar to the upper layer pyroxenite, although in hand specimen it is a light green colour rather than the dark colour of the upper layer. Limonite nodules are very common near the contact with the olivine pyroxenite.

Kinking and other deformational features will be discussed more fully in section IV.

Comparison of Lower and Upper Layers

1. Petrology

The main petrological differences can be summarised as follows:

(a) Bronzites are more commonly zoned in the lower layer.

(b) Olivine only occurs in the lower layer. Consequently the characteristic coronal rims around olivines only occur in. the olivine pyroxenite.

(c) Spinel is much more common in the lower layer.

(d) Clinopyroxene phenocrysts only occur in the upper layer, although small grains are found in both.

(e) Plagioclase in the lower layer contains green oriented inclusions.

(f) Biotite, and opaques, generally become rarer to the top of the intrusion.

(g). The lower layer is coarse grained, while the upper layer 
varies from medium grained at its base to coarse grained at the top.

2. Chemical Variations

The chemical analyses of both whole rocks and bronzites (Table 1) of A300-127 (olivine pyroxenite) and A300-116 (pyroxenite) show a marked enrichment of $\Sigma \mathrm{Fe}$ relative to $\mathrm{MgO}$ (fig. 13) towards the top of the intrusion.

\begin{tabular}{|l|c|c|}
\hline Whole Rock & $\Sigma \mathrm{Fe} / \mathrm{MgO}$ & CaO/MgO \\
\hline A251-N248 & 0.35 & 0.27 \\
A300-127 & 0.23 & 0.12 \\
A300-116 & 0.31 & 0.29 \\
\hline Bronzite & & \\
\hline A300-127 & 0.23 & 0.13 \\
A300-116 & 0.32 & 0.08 \\
\hline
\end{tabular}

Fig. 13

This relationship can be seen in fig. 14 where the differentiation trend (if permissable to be drawn) is similar in position and direction to that of the Mt. Davies Intrusion (Nesbitt and Kleeman, 1964). Note: $\Sigma F e$ was calculated as FeO.

This trend is somewhat paralleled by CaO/MgO (fig. 13), except in the case of the bronzites. The unusual enrichment in 127 could be due to the non-existence of clinopyroxene as a primary precipitate in the lower layer. This could possibly result in an unusual amount of $\mathrm{CaO}$ being incorporated in the bronzite lattice. 
TABLE 1

\begin{tabular}{|c|c|c|c|c|c|}
\hline & $\begin{array}{c}\text { A300-127 } \\
\text { Whole Rock }\end{array}$ & $\begin{array}{c}\text { A300-116 } \\
\text { Whole Rock }\end{array}$ & $\begin{array}{c}\text { A251-N248* } \\
\text { Whole Rock }\end{array}$ & $\begin{array}{c}\text { A300-127 } \\
\text { Bronzi te }\end{array}$ & $\begin{array}{c}\text { A300-116 } \\
\text { Bronzi te }\end{array}$ \\
\hline $\mathrm{Al}_{2} \mathrm{O}_{3}$ & 4.04 & 4.38 & 8.10 & 4.57 & 7.59 \\
$\mathrm{\Sigma Fe}$ & 7.47 & 6.61 & 8.25 & 6.74 & 9.33 \\
$\mathrm{MgO}$ & 33.0 & 21.2 & 23.4 & 29.6 & 28.9 \\
$\mathrm{CaO}$ & 3.90 & 6.13 & 6.40 & 3.98 & 2.33 \\
$\mathrm{MnO}$ & 0.17 & 0.18 & 0.16 & 0.18 & 0.25 \\
$\mathrm{Na}_{2} \mathrm{O}$ & 0.51 & 0.52 & 1.08 & 0.38 & 0.10 \\
$\mathrm{~K}_{2} \mathrm{O}$ & 0.14 & 0.14 & 0.38 & 0.02 & 0.04 \\
\hline
\end{tabular}

* Denotes analysis by A.M.D.L.

20

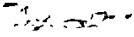

Mode

\begin{tabular}{|l|c|c|}
\hline & A300-127 & A300-116 \\
\hline Pyroxene & 45.8 & 88.2 \\
Olivine & 36.6 & - \\
Spinel & 2.9 & traces \\
Plagioclase & 1.9 & 6.5 \\
Biotite & 1.1 & 5.2 \\
Groundmass* & 11.7 & - \\
\hline Specific Gravity & 3.353 & 3.305 \\
\hline
\end{tabular}

* Groundmass - mainly granulated olivine and pyroxene. 


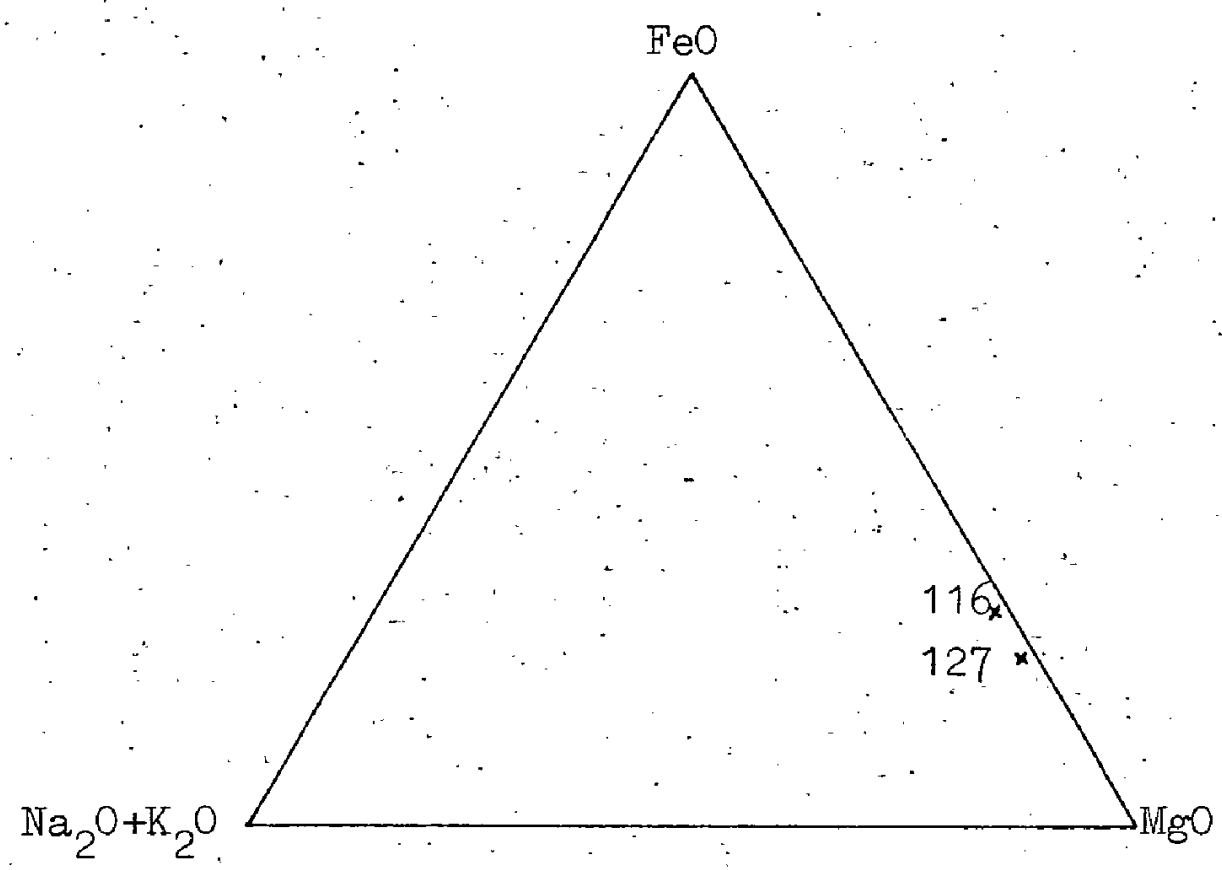

Fig. 14

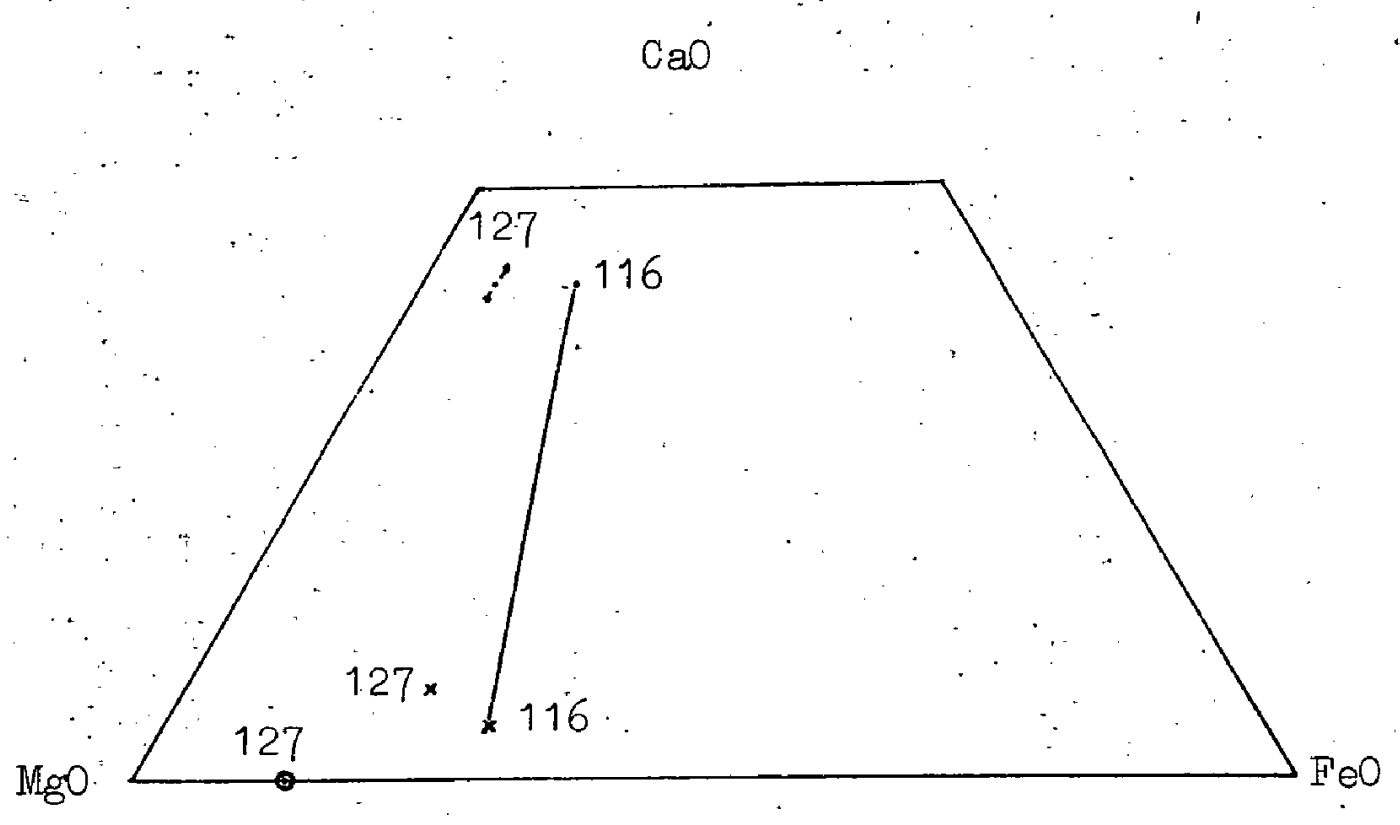

Fig. 15

$$
\begin{aligned}
& \therefore \text { Olivine } \\
& \times \quad \text { Orthopyroxene } \\
& \text { - Clinopyroxene }
\end{aligned}
$$


Fig. 15 shows the chemical distribution of pyroxenes and olivine. No tie line is drawn between clino- and orthopyroxenes of 127, as they did not form in the same environment. Olivine 127 is richer in MgO than its corresponding bronzite, possibly due to its earlier formation. The observed "trend" is in keeping with that of expected differentiation.

No immediate explanation is offered for the anomalous $\mathrm{A}_{2} \mathrm{O}_{3}$ content of bronzite 116 (Table 1), other than that previously mentioned in Section II.

A251-N248, from near the contact (analysed by A.M.D.L.) shows anomalous values of $\Sigma \mathrm{Fe} / \mathrm{MgO}, \mathrm{CaO} / \mathrm{MgO}$, alkalis and alumina. These probably result from country rock contamination.

Optical determinations (Table 2) show a marked break between the two layers in plagioclase and orthopyroxene (from Hess, 1952) compositions. Clinopyroxene may not give valid variations as it exists as different forms in both layers.

(1) Plagioclase:

$$
\begin{array}{ll}
\text { Lower Layer } & \mathrm{An}_{30} \\
\text { Upper Layer } & \mathrm{An}_{45-60}
\end{array}
$$

\section{(2) Orthopyroxene}

The tip heap traverse shows a hiatus in composition.

$$
\begin{array}{ll}
\text { Lower Layer } & \mathrm{En}_{88-89} \\
\text { Upper Layer } & \mathrm{En}_{82-84}
\end{array}
$$

Plagioclase compositional variation in the upper layer is random, but in the tip heap traverse the orthopyroxene shows a small but. regular enrichment in iron towards the top of the 
TABLE 2

Plagioclase Compositions (after Smith and Yoder, 195
\begin{tabular}{|l|c|c|}
\hline & $2 \theta(1 \overline{3} 1)-2 \theta(131)$ & $\begin{array}{c}\text { Mole Percent } \\
\text { Anorthite }\end{array}$ \\
\hline A300-127 & 1.75 & $<0$ \\
A300-116 & 1.90 & 62 \\
A300-30 & 1.97 & 67.5 \\
A300-83 & 1.91 & 62 \\
A300-105b & 1.91 & 62 \\
A300-7 & 1.88 & 61 \\
\hline
\end{tabular}

Olivine Compositions (after Yoder and Sahama,
\begin{tabular}{|c|c|c|}
\hline & $2 \theta(130)$ & $\begin{array}{c}\text { Mole Percent } \\
\text { Forsterite }\end{array}$ \\
\hline A300-127 & 32.274 & 88 \\
A300-91 & 32.253 & 85.5 \\
\hline
\end{tabular}

Orthopyroxene Compositions

\begin{tabular}{|c|c|c|c|c|c|}
\hline & $2 \mathrm{~V}$ & $\begin{array}{c}\text { Mole Percent } \\
\text { Enstatite }\end{array}$ & 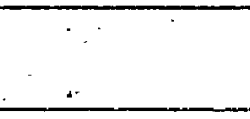 & $n_{\beta}$ & $\begin{array}{c}\text { Mole Percen } \\
\text { Enstatite }\end{array}$ \\
\hline A $300-37$ & $(-) 86$ & 85 & A. $300-113$ & 1.679 & 85 \\
\hline A $300-40$ & (-) 87 & 85 & A $300-117$ & 1.681 & 84 \\
\hline A $300-43$ & $(-) 87$ & 85 & A $300-118 a$ & 1.682 & 83 \\
\hline A $300-45$ & $(-) 88$ & 86 & $A 300-118 b$ & 1.682 & $83^{\prime \prime}$ \\
\hline A $300-47$ & -90 & 87 & A $300-120$ & 1.682 & 83 \\
\hline A $300-127$ & $(+) 88$ & 88 & A $300-122$ & 1.683 & 82 \\
\hline & & & A $300-124$ & 1.682 & 83 \\
\hline . : & & & A $300-126$ & 1.680 & 84 \\
\hline . & & & A300-127 & 1.672 & 89 \\
\hline . & : & & $A 300-128$ & 1.671 & 90 \\
\hline
\end{tabular}


TABLE 2 (Cont.)

Clinopyroxene Compositions

\begin{tabular}{|l|c||l|c|l|}
\hline & $2 V$ & & $n_{\beta}$ & Composition \\
\hline A300-45 & $(+) 60$ & A300-116* & 1.688 & $\mathrm{En}_{38^{\mathrm{Fs}}} \mathrm{Wo}_{50}$ \\
& & $\mathrm{~A} 300-127$ & 1.680 & \\
\hline
\end{tabular}

* $2 \mathrm{~V}=60$ assumed.

Modes

\begin{tabular}{|l|c|c|c|}
\hline & Plagioclase & Pyroxene & Biotite \\
\hline A300-116 & 6.5 & 88.3 & 5.2 \\
A300-117. & 4.2 & 95.8 & - \\
A300-118a & 2.7 & 97.3 & - \\
A300-119 & 0.3 & 99.7 & - \\
A300-120 & 1.3 & 98.7 & - \\
A300-121 & 1.6 & 98.4 & - \\
A300-122 & 5.0 & 94.8 & 0.2 \\
A300-123 & 2.2 & 97.6 & 0.2 \\
A300-124 & 4.7 & 94.4 & 0.9 \\
A300-125 & 3.3 & 96.2 & 0.5 \\
A300-126 & 2.0 & 97.8 & 0.2 \\
\hline
\end{tabular}


intrusion. This is not observed so well in the camp traverse (possibly indicating the relative reliability and accuracy of the two methods, $n_{p}$ and. $2 \mathrm{~V}$, in the circumstances). Variations in the lower layer are not observable due to the small number of samples.

\section{Mafic Pegmatites}

1. Field Relationships

Commonly in the contact zone and also in the olivine pyroxenite, cross-cutting veins of mafic pegmatites up to several feet in width are observed.

\section{Petrólogy}

They are coarse grained, and consist predominantly of light green plagioclase and dark green pyroxene.

In thin section $(A 300-20)$ they have a recognisable though not sharp contact with the host rock. The pegmatite is much more coarse grained, richer in plagioclase and although deformed. not as granulated as the host rock.

\section{Plagioclase.}

Plagioclase occurs usually as 5-10 mm anhedral grams, exhibiting undulose extinction. Twinning is poor and a composition of $\mathrm{An}_{40}$, which was obtained should be treated with caution. The majority of grains show antiperthitic texture and/or small light green euhedral inclusions. These in general do not form together.

The antiperthite consists of $0.2-0.3 \mathrm{~mm}$. stringers of potassium feldspar in the plagioclase host. 
The clouds of light green inclusions commonly. show stubby to needlelike rhombohedral sections, similar to those in the plagioclase of the olivine pyroxenite. They are strongly aligned parallel to twinning.: They appear to be antipathetic to. foreign inclusions (e.g. pyroxene) in the plagioclase (Plate 18) and" do not form in their vicinity. In some cases, there appears to be a gradation between the coarser, anhedral inclusions seen in the hybrid zone and the finer, euhedral, more aligned inclusions described above and in the olivine pyroxenite.

Rounded, anhedral pyroxene grains tend to accumulate on the boundary "of some antiperthite grains and apatite grains. In some cases, they form a granular intergrowth with ismali. plagioclases radial to the interface (Plate 23 ).

\section{Orthopyroxene:}

The orthopyroxenes form in $1-3 \mathrm{~mm}$ subhedral grains, and exhibit the usual strong pleochroism. They are optically negative.

Exsolution occurs in the form of "blebs" of clinopyroxene and Iong plates of opaque material in $\{010\}$ paraliel to $c$. Inclusions of smaller pyroxenes are common."

\section{Biotite.}

Biotite occurs as strongly pleochroic ( $z=$ red brown) 2-6 mm anhedral flakes. The larger grains are strongly distorted and often poikilitic, containing feldspar inclusions. 


\section{Opaques.}

Opaques are anhedral, and occur up to $1-2 \mathrm{~mm}$ in size. They are commonly associated with spinel and tend to enclose them.

\section{Apatite.}

Apatite occurs as subhedral accessory grains up to $2 \mathrm{~mm}$

\section{long.}

\section{Minor Intrusions}

There are a number of smaller intrusive bodies near the main intrusion, most of which are petrologically similar to : either the upper or lower layers of the main intrusion. 1. Gabbroic Dykes

These form as a set of broad dykes whose arcuate outcrop pattern.is explained by their shallow easterly dip and the topography. Four of these dykes are situated south of the eastern lobe, and a fifth near the western end of the main body all are discordant with the metamorphic layering: A300-23, 205 contain euhedral to subhedral bronzites and interstitial plagioclase (approx. $A n_{40}$ ), which are medium to fine grained, set in a mosaic of fine grained $(0.1 \mathrm{~mm})$ equant clinopyroxenes. Traces of biotite and opaque are found also. Considerable alteration of the pyroxene to hornblende is evident, andindicates hydrous conditions of formation.

The unusual amounts of plagioclase (20\%) and the postulated presence of water suggest ta lower intrusive viscosity than that of the magma of the main intrusion and this may explain their 
dyke-like nature.

A300-110 is coarser, but of a similar texture. Augite $(60 \%)$ and plagioclase. (30\%) are the dominant minerals with biotite and some $1 \mathrm{~mm}$ bronzites also present. These bronzites are set in a granular groundmass $(0.4 \mathrm{~mm})$ of augite and interstitial plagioclase.

These dykes are petrologically similar (except for the biotite and hornblende) to the upper layer of the intrusion,

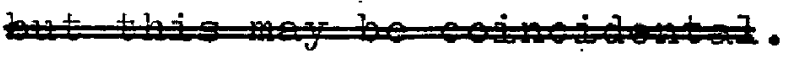

These are the first reported occurrences of dyke-like intrusions in the Giles Complex.

\section{Small Plug-Like Intrusions}

Two small plugs, A300-79 and A301-153 are described in this group. A300-77 of a similar nature, is described with the olivine pyroxenite.

A301-153 is a coarse grained hypidiomorphic rock with large euhedral plagioclase laths $(8 \times 2 \mathrm{~mm}$ to $3 \times 1 \mathrm{~mm})$ showing a strong preferred orientation that suggests a flow texture. Plagioclase constitutes $60 \%$ of the rock with pyroxene (mainly augite with some bronzite) as the most abundant interstitial material. About $5 \%$ olivine is present as fractured, medium sized grains, each enclosed by a coronal rim of orthopyroxene and a green vermicular intergrowth when in contact with plagioclase.

Plagioclases are often clouded with minute green rod shaped euhedral inclusions. 
Orthopyroxenes contain brown plate-like intergrowths with thin colourless needle-like exsolutions also present. Clinopyroxenes exsolve blebs of orthopyroxene on $\{100\}$. Biotite and opaques often occur together as irregular patches but not in any quantitiy.

A300-79 is mineralogically similar to A301-153. Plagioclases are optically continuous for up to $15 \mathrm{~mm}$, but: are very much interrupted by pyroxene grains. They are also crudely aligned.

The bronzites in both cases contain crossed sets of fine dark needles near the rim, similar to bronzites in A300-84. The above features are characteristic of the olivine pyroxenite, except for the higher percentage of plagioclase. As in the gabbroic dykes, this may represent a higher mobility of the magma.

3. Small Lenticular Intrusions

Two smali lenticular intrusions are elongate in an eastwest direction (i.e. perpendicular to the Giles Complex dykesh A301-175 is situated half a mile north of the main intrusion and A301-190 is in the south-east corner of the mapped area. Though similar in some respects to the Giles dykes, their texture, mineralogy and attitude warrant their discussion as a separate group.

A301-190 is a medium grained granular rock consisting of subhedral pleochroic bronzite (70\%) and patchy to subhedral. intergranular horriblende. (30\%) from 1 to $2 \mathrm{~mm}$ in size. 
Unlike the Giles dykes, there is no plagioclase, augite or biotite and the rock shows no signs of granuiation." A few grains, however, show incipient kinking. Dark smudges of minute inclusions, often concentrating into opaque patches and usually aligned parallel to cleavage directions, are common in both bronzite and hornblende.

A301-175 is quite similar to A301-190. It is, however, somewhat finer grained (commonly $1 / 2 \mathrm{~mm}$ to $11 / 2 \mathrm{~mm}$ ) and shows a paucity of hornblende - only a few small scattered patches which occur as alteration products around the bronzite. Inclusions similar to those in $\$ 301-190$ are very abundant in the rock, giving the thin section a cloudy appearance. Kinking is quite common among the bronzites, and the kink planes show a strong preferred orientation. (see Section IV). 4. Anorthosite (A300-105b)

The anorthosite occurs as a thin dyke-like body about $1 / 4$ mile north of the main intrusion. It is closely associated with a large shear and may well be semi-continuous alang the shear to coincide with a similar body to the north-west of the mapped area on the same shear.

It characteristically forms a light grey pebbly surface in weathered outcrop, but fresher samples are dark grey.

It is coarse grained, the plagioclase laths usually being $3 \times 1 \mathrm{~mm}$, although crystals up to $10 \times 2 \mathrm{~mm}$ are not uncommon. Pyroxenes generally form quite equant grains between 1 and $2 \mathrm{~mm}$ in diameter. Undoubtedly because of the close association to 
a once active shear, the rock shows many deformational features which have overshadowed much of the original textural features. The coarse pyroxene and plagioclase occur in a groundmass of finer grained granulated material.

\section{Plagioclase.}

Plagioclase forms $90 \%$ of the rock and has a composition of An $_{62}$ (X-ray measurement).

The plagioclase laths appear to have been originally euhedral but are now often curved and distorted. Albite and pericline glide twinning form in preference to primary twinning, and splitting or divergence of twins common. Undulose extinction is usual.

The crystals are very often zoned. In all crystals there is an outer antiperthite zone, about $0.2 \mathrm{~mm}$ wide, with stringers of potassium feldspar in the host plagioclase. This zone does not occur when plagioclase is in direct contact with large pyroxene grains. Inside this zone oriented thin exsolution needles about $0.03 \mathrm{~mm}$ in length occur (Plate 43). These. purple red exsolutions (refractive index greater than that of plagioclase) are sometimes in the form of globule trails up to $0.3 \mathrm{~mm}$ in length.

\section{Pyroxene.}

The pyroxenes are usually partially broken up and show undulose extinction. Some exhibit pink-green pleochroism and commonly contain dark brown oriented plates (probably an iron oxide). They may have been originally subhedral, to euhedral. 
Both ortho- and clino-pyroxenes are possibly present. Opaques are quite common and appear to be largely of a secondary nature, filling cleavages and fractures. Hormblende occurs occasionally as small flakes (alteration of pyroxene).

\section{Groundmass.}

The cataclastic groundmass is approximately 0.1 to $0.2 \mathrm{~mm}$ in size. It consists of pyroxene and feldspar. The feldspar often occurs as lenticular anhedra exhibiting "flow texture" around large laths (Plate 43). This appears to indicate some degree of mobilization (inherent or induced) during deformation. This texture sometimes has a "myṛmekitic" appearance. 
The Giles Complex intrudes a region of high grade metamorphic rocks of the granulite facies. On the basis of field observation it is convenient to divide this country rock into two broad groups - the augen gneiss and the banded gneiss. Interlayered with these gneisses are numerous quartz-feldspar bands (often garnet bearing), mylonites, and two other rock types given the field names speckled granulite and black granulite.

The Augen Gneiss

The augen gneiss ${ }^{*}$ is a massive rock in which the aligned augen define the layering. The augen are virtually lensoid aggregations of perthite and plagioclase ranging in size from $1 / 2 \mathrm{~cm}$ up to $4 \mathrm{~cm}$. They consist predominately of medium-grained perthite with a few coarser perthites up to $3 \mathrm{~mm}$, and medium to fine-grained twinned plagioclase sometimes slightly bent. Perthites show abundant exsolved plagioclase either as oval blebs or as elongate lenses. The augen may contain a few. quartz grains but ferromagnesian minerals are virtually absent. Garnet, hypersthene and opaques in roughly equal proportions, and augite in lesser amounts form about $30 \%$ of the material enclosing the augen whilst perthite, plagioclase and quartz constitute the remaining 70\%. Apatite occurs as an accessory mineral. The grains are arranged essentially in a granoblastic manner but with the ferromagnesian minerals crudely aligned. Grain size is varied, and ranges from $0.2 \mathrm{~mm}$ 
to $1.0 \mathrm{~mm}$.. Much of the quartz and feldspar throughout the rock shows slightly undulose extinction.

Although pyroxenes and opaques sometimes occur as isolated grains, normally they are associated intimately with garnet in a way that suggests a reaction relation between all three and the adjacent feldspar and quartz. The garnets occur either as very irregular poikiloblastic masses or as myrmekitic-like patches crowded with tiny vermicules (Plates 39,40). These poikiloblasts and vermicules within the garnet are too small to identify with certainty but some appear to be quartz whilst others, possibly, are feldspar.

The Banded Gneiss.

The banded gneiss is distinguished from the augen gneiss purely on field appearance. Mineralogically, the two are quite similar athough a greater abundance of plagioclase and augite occurs in the banded gneiss than in the specimens of augen gneiss available in thin section. The hand specimen exhibits a crude layering resulting from the irregular alignment of ferromagnesian minerals.

The common mineral assemblage which characterises the banded gneiss (and the augen gneiss) is hypersthene - augite plagioclase - opaques. Small amounts of biotite occur in A301-115, and garnet occurs in A301-166A. A plagioclase composition of $\mathrm{An}_{30}$ was determined for $\mathrm{A} 301-4$ from a section normal to the 'a'-crystallographic axis.

These rocks are generally medium-grained with common grain 
size ranging from $1 / 2 \mathrm{~mm}$ to $11 / 2 \mathrm{~mm}$. Very often the plagioclases are sharply twinned and may display multiple twinning. Textural equilibrium is indicated by the sharp triple point junctions notably between the plagioclases (Voll, 1960). Elsewhere, as in A301-166A, grain boundaries are markedly irregular and often interpenetrant on a small scale, a feature which is emphasized by the abundance of smaller-grained material mixed with the larger. Glide twinning and slight bending of plagioclases occur, and quartz grains often exhibit dislocation boundaries. Quartz-feldspar Layers

Numerous quartz-feldspar bands, with or without garnet, are found throughout the country rock and are conformable with the metamorphic layering. These bands range up to $150 \mathrm{ft}$. in width. Commonly, they outcrop as white flaggy low ridges, sometimes crumbly, with the layering usually defined by irregular strings of pink or rusty-red garnet. The characteristic minerals are quartz and perthite. These rocks are generally medium-grained with occasional coarser-grained and finer-grained layers.

In thin section therocks consist of quartz and perthite (together forming $70 \%$ to almost $100 \%$ of the rock), garnet $(0-20 \%)$, plagioclase (0-15\%), antiperthite (abundant in A301-156 but rare elsewhere), opaques $(1-5 \%)$, biotite $(0-5 \%)$ with sillimanite and spinel as accessories. From X-ray determination the antiperthite contains $18.9 \%$ of the K-feldspar molecule. Chemical analysis 
and determination of cell size (Table z) indicates the garnet to be greatly enriched in the almandine molecule with some pyrope (Deer, Howie, Zussman, Vol. I, 1963). The theoretical cell size of the garnet was determined (ạsuming no andradite) from chemical analysis and agreed closely with the measured value.

Quartz normally shows undulose extinction and dislocation boundaries whilst grain boundaries vary from slightly irregular to strongly re-entrant or sutured.

Perthite exsolves plagioclase as veins or, more usually, as blebs. This exsolved plagioclase is sometimes twinned. Garnet grains tend towards xeofiblastic form and are often elongate in the direction of layering: Extensive fracturing and sometimes fragmenting is common. Opaques and biotite are associated with the garnet in some specimens, and $A 301-26 \mathrm{~A}$ contains inclusions of spinel, opaques and quartz in the garnet. Plagioclase usually occurs as small twinned grains, sometimes slightly bent and $A 301-16 \mathrm{~B}$ shows a myrmekitic-like structure.

Antiperthite is rare, generally, but A301-156 contains possibly $40 \%$ of this material.

Opaques usually occur as small grains $(0.2 \mathrm{~mm})$ ranging from idioblastic form to irregular interstitial patches commonly associated with garnet.

Biotite is intimately associated with opaques and garnet and occurs as fine-medium grained flakes and patches, which are 
PABLE 3

\begin{tabular}{|l|c|}
\hline & $\begin{array}{c}\text { A301-156 } \\
\text { Garmet }\end{array}$ \\
\hline $\mathrm{A}_{2} \mathrm{O}_{3}$ & 19.9 \\
$\Sigma \mathrm{Fe}$ & 23.8 \\
$\mathrm{MgO}$ & 7.07 \\
$\mathrm{CaO}$ & 0.65 \\
$\mathrm{MnO}$ & 0.55 \\
\hline
\end{tabular}

Gamet Cell Size

1. Measured (X-ray)
$a=11.517 \AA$

2. Theoretical (from chemistry)

$a=11.519 \AA$

\begin{tabular}{|l|c|}
\hline & A301-72* \\
\hline $\mathrm{K}_{2} \mathrm{O}$ & 3.60 \\
$\mathrm{U}(\mathrm{ppm})$ & 0.90 \\
$\mathrm{Th}(\mathrm{ppm})$ & 2.5 \\
\hline
\end{tabular}

* Analysis by I. Lambert. 
strongly pleochroic. The biotite is of the deep reddish-brown variety. .

Accessories include spinel and sillimanite which sometimes occur together.

Mylonites

In the mylonitic bands quartz and opaque material occur as strongly deformed irregular string-like grains and layers. Although almost all quartz rich rocks show some degree of deformation, the strongly mylonitized rocks occur near known shears, the only apparent exception being A300-74. Commonly, sillimanite is abundant, and is scattered throughout the rock as strongly idioblastic grains which are elongate in the direction of foliation or which show characteristic, almost square, cross-sections. The sillimanites are not particularly fractured and show virtually no fragmentation indicating that they post-date the mylonitization.

Black Granulite (A300-58)

Dark coloured basic granulites occur in thin bands generally a few feet in width, conformable to the metamorphic layering, and often exhibiting a fine lamination.

In thin section they consist of approximately $40-60 \%$ garnet, $10-20 \%$ plagioclase, $20 \%$ clinopyroxene and 5\% opaque, with spinel as accessories. The majority of constituents are 1-2 $\mathrm{mm}$ in diameter. Hornblende (up to 20\%) occurs in some rocks (A300-63) at the expense of clinopyroxene. 
(1) Plagioclase forms xenoblastic grains up to about $1 \mathrm{~mm}$ in diameter. Glide twinning is common. Some grains are poikiloblastic, containing inclusions of clinopyroxene.

(2) Garnets are somewhat idioblastic, and often show good triple point junctions. They commonly contain oriented $0.01 \mathrm{~mm}$ intergrowths of a dark brown material, possibly rutile (Plate 38 ). These intergrowths are nearly always in the central cores of the garnets.

(3). Cilinopyroxene occurs as anhedral grains, often with aligned bladed opaque intergrowths.

(4) Opaque areas are unusually coarse grained $(1, \mathrm{~mm})$ and sometimes contain inclusions of spinel. In one case colourless spindle inclusions with orthorhombic extinction were observed. (5) Hornblende forms as anhedral pleochroic (light to dark brown green), grains up to $2 \mathrm{~mm}$, and appears to be replacing the pyroxene. They occasionally contain oriented opaque intergrowths, which may be relics from the replaced pyroxene. (6) Biotite was rarely observed, and; appeared secondary. Pleochroic scheme is light to dark brown.

Two black granulites studied from the west of the area. (A300-93, 22) did not contain any garnet, and consisted mainly of plagioclase andorthopyroxene, with a little clinopyroxene. Speckled Granulite (A300-7)

The speckled granulite has a characteristic texture which is easily identifiable in the field. It is even grained. $(0.5$ to $1 \mathrm{~mm})$ and possesses a rough layering. 
The rock contains roughly equal amounts of subhedral ortho- and clino-pyroxenes $(30-40 \%)$, plagioclase $(60 \%)$, opaques (less than 5\%) and accessory apatite. The opaques are intimately associated with the pyroxene.

(a) Orthopyroxene

Hypersthene is present as strongly pleochroic grains.

(b) Clinopyroxene

Clinopyroxene is a deeper green than the hypersthene, and commonly contains bladed opaque intergrowths.

(c) Plagioclase

A300-? gave a composition of $A_{61}$ by X-ray diffraction methods:

(d) Biotite

This mineral is observed occasionally as brown pleochroic grains.

Grain boundary relationships indicate textural equilibrium since triple point junctions are commonly observed (Voll, 1960).

In some cases pyroxene is found altering to brown hornblend (Plate.37) with opaques and plagioclase related. This is probably due to slightly hydrous conditions during metamorphism, rather than any retrograde effect.

Discussion of Metamorphism

1. Grade of Metamorphism

The:common mineral assemblages observed were:

(1) augen-banded gneiss

quartz - perthite - plagioclase - orthopyroxene - 


$$
\text { clinopyroxene - garnet - opaques. }
$$

(2) quartz-feldspar bands

$$
\text { quartz - perthite (- garnet - sillimanite - plagioclase). }
$$

(3) speckled granulite

$$
\text { plagioclase - orthopyroxene - clinopyroxene - opaques. }
$$

(4) black granulite

(a) plagioclase - clinopyroxene - garnet - opaques

(b) plagioclase - orthopyroxene - clinopyroxene - opaques.

These assemblages are typical of the pyroxene granulite subfacies (Turner and Verhoogen, 1960). The significance of the presence of hornblende and biotite in some specimens will be discussed later.

The above assemblages can be further subdivided (de Waard, 1965) on the basis of varying load pressure and water pressure. The varying assemblages corresponding to varying bulk compositions are plotted on ACF and AFK diagrams (fig. 16 ). It is immediately noticeable that although water pressure remains constant, load pressure indications vary.

All thin sections of speckled granulite studied correspond to the orthopyroxene-plagioclase (op-pl) subfacies of de Waard.

The garnet bearing black granulites belong to the clinopyroxene-almandine (cp-al) subfacies, while the garnet free specimens belong to the op-pl subfacies. Most of the augen-banded gneiss assemblages reveal a more complex relationship. The intimate association of altered orthopyroxene, plagioclase, opaques, clinopyroxene (generally 


\section{Fig. 16}

Metamorphic Mineral Assemblages

a. Speckled Granulite.

b. Quartz-feldspar bands.

c. Augen-banded Gneiss.

d. Black Granulite. 
Fig. 16 Metamorphic Mineral. Assemblages

Op-Pl Subfacies

$a$

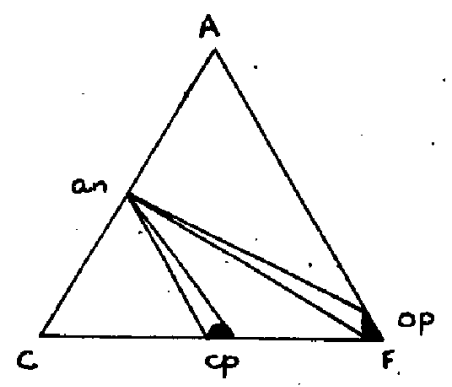

b

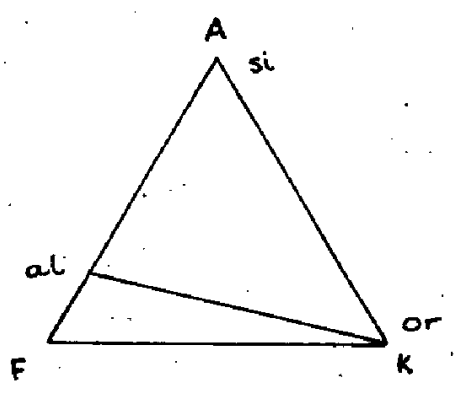

$c$

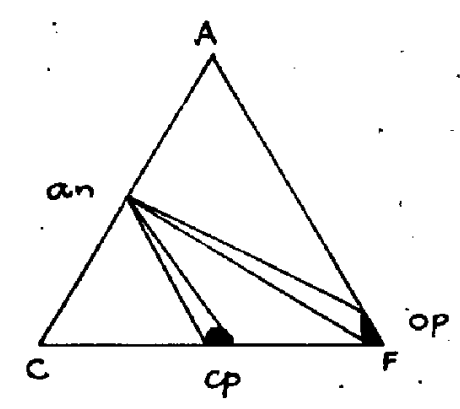

d

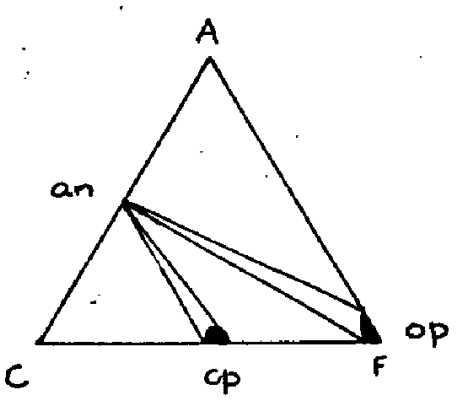

Cp-Al Subfacies
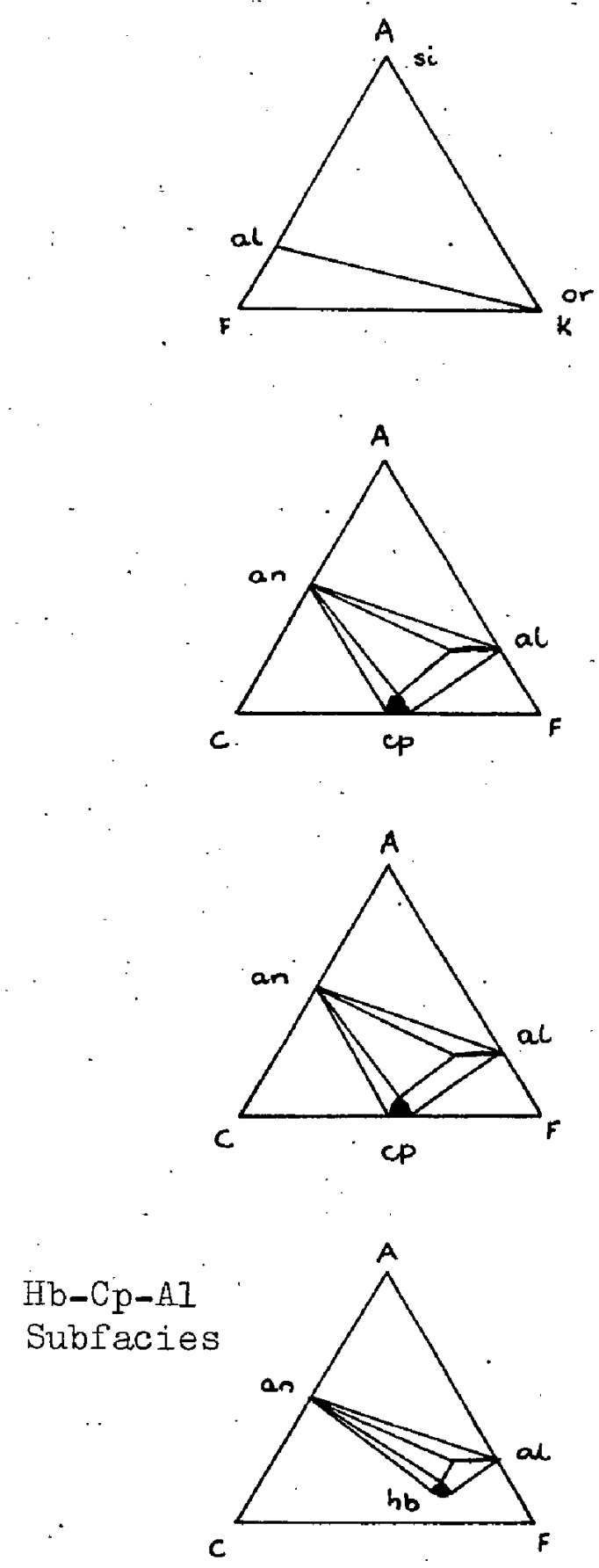
fresher looking than the orthopyroxene) and symplectic garnet (with probably quartz inclusions) could possibly be caused by a reaction marking the transition between the subfacies orthopyroxene + plagioclase - garnet + clinopyroxene + quartz

$$
\text { ( } \pm \text { opaque) }
$$

$$
(\mathrm{op}-\mathrm{pl})
$$

$$
(c p-a l)
$$

A. similar reaction involving garnets containing dactylitic quartz and with a similar texture is recorded by de Waard (opaques are not involved in his postulated reaction).

An augen gneiss containing an op-pl assemblage only was observed at A301-123a.

The quartz-perthite assemblages are not characteristic of either subfacies.

Although much more detailed work is required, it is noticeable that all examined thin sections of assemblages corresponding to the cp-al subfacies (or showing the transition reaction above), with the exception of A301-166A, come from the granulite "island" south of the intrusion ( $f$ ig. 17 ). This area forms part of the core of a major fold (Davies. Sheet, 1964) which could possibly account for the higher load pressure conditions postulated. If, however, on future study, both subfacies are found represented in a thinly interbanded sequence, some revision of de Waard's classification may prove necessary. 


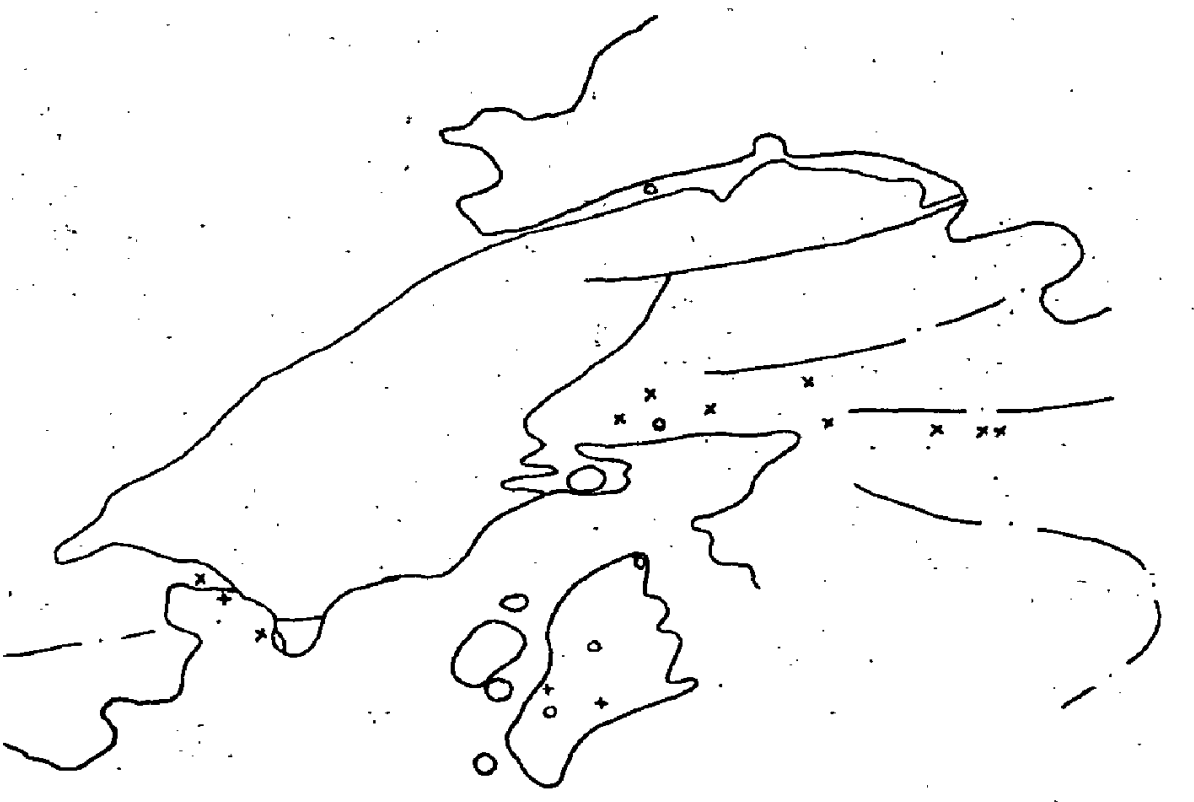

Fig. 17
× Speckled Granulite

+ Black Granulite

D. Augen: - Banded Greiss

$$
\begin{aligned}
& \text { op-pl subfacies } \\
& \text { cp-al subfacies (or } \\
& \text { mixed assemblage) }
\end{aligned}
$$

2. Presence of Hornblende

The large concentrations of hornblende which occur in some rocks (A300-63, 66) are probably not related to the initial metamorphism or to retrograde effects. The characteristically coarse tabular crystals of hornblende are invariably found near the intrusive contacts of the Giles Complex in ferromagnesian rich rocks. A300-63, which represents essentially the same band as $A 300-58$ but which is nearer the contact, contains abundant hornblende whereas A300-58 contains negligible. quantities. These concentrations are possibly due to a contact aureole around the intrusions, giving rise to increased quantities of water, at essentially granulste facies conditions. This aureole could be physically represented by the "hornfelsic" hybrid zone of the intrusions, although, as stated, its chemical 
effects could extend further.

Minor quantities of brown-green hornblende forming at the expense of pyroxene (Plate 37), and biotite, in rocks further from the intrusion could be due to the contact aureole or to slightly hydrous conditions during regional metamorphism.

3. Garnets from Acid and Basic Granulites

Garnets from the quartz-potash feldspar bands and from the black granulites differ in at least one respect. The basic garnets exhibit a cored zone of needle exsolutions (Plate 38), possibly rutile.

This is probably a manifestation of original bulk rock composition, the black granulites being richer in $\mathrm{TiO}_{2}$ (?), as could be expected.

4. Distribution of Sillimanite

The strongly mylonitized rocks are confined to quartzperthite bands which may be an expression of the ease of deformation of quartz and feldspar compared to the ferromagnesian minerals. These mylonites often contain unusual amounts (up to. 15\%) of sillimanite. This is possibly due to

(i) an unusual association of a highly pelitic rock and a strong shear, or

(ii) a redistribution of alumina by the shear, causing an accumulation in the quartz rich layers in which the shear preferentially occurs. This is more likely as the sillimanite appears to have formed after the shearing. In this case the amount of sillimanite present would 
depend on initial rock composition of both the quartz band and the neighbouring rocks, as well as the strength of the shear.

5. Discordant Felsic Veins

A.t A300-57 in an augen gneiss on the granulite "island". south of the main intrusion, fine grained felsic veins were observed (Plate 8). Apart from a difference in grain size, the vein was also different in other respects to the host rock. (1) Light green acicular inclusions were found in potash feldspar in the vein.

(2) Hornblende was much more common in the vein, and was the only ferromagnesian mineral present. These veins could have perhaps developed by two means. (1) Selective mobilization during high graide regional metamorphism.

(2) "Phgatitic" emanations associated with the underlying ultrabasic intrusion.

6. Uranium-Thorium Content

A. sample of augen gneiss (A301-72) analysed by I. Lambert shows a low thorium and uranium content. (Table 3). The low uranium content could be due to its mobilization during high grade metamorphism (Heier and Adams, 1965). 
These dykes commonly occur as smooth, dark green walls, a few feet thick, in both country rock and Giles Complex intrusives. They are fine grained and often well jointed. Some show evidence of chilled margins, and, more rarely, banding.

Thin sections show characteristic anhedral clinopyroxene (1 mm) grains in a matrix of finer grained anhedral pyroxene $(0.03 \mathrm{~mm})$, plagioclase $(0.2$ to $0.4 \mathrm{~mm})$ and hornblende, arranged in a subophitic manner. Spinel and opaques are accessories $(A 300-10)$.

The coarser clinopyroxenes are usually roughly lens shaped and are strongly deformed in concordance with the general textural features. Kink bands are arranged in sheaf or. partial sheaf-like forms. Simple twinning is occasionally observed.

Plagioclase forms as irregular laths, and commonly exhibits carlsbad twinning.

A characteristic feature of the dykes are the "clumped" areas (Plate 42). These are formed of isotropic areas up to $5 \mathrm{~mm}$ in diameter, and may also contain large clinopyroxenes and plagioclases, as well as anhedral grains $(0.06 \mathrm{~mm})$ of pyroxene, spinel and plagioclase. These areas are light green in colour, yet exhibit remarkable isotropic extinction.

Sometimes these areas contain oval shaped "amygdaloidal" groups of a low birefringent mineral with moderate relief. 
Anhedral $(0.2 \mathrm{~mm} \times 0.1 \mathrm{~mm})$ grains are arranged in a radial aggregate (Plate 41 ). This mineral has $2 \mathrm{~V}_{\mathrm{x}}=70-80^{\circ}$ (it may be a potassium feldspar - microcline). These grains have vermicular opaque material often associated.

Both the clumps and the oval aggregates appear to be of secondary origin.

Sheared contacts are sometimes observed with the country rock (A301-144). The granulite is broken into subangular blocks (between $1 \mathrm{~mm}$ and $2 \mathrm{~mm}$, and coarser), and fracture filling with opaque material and granules of country rock has occurred. The fine grained dolerite has incorporated subhedral to euhedral 1-2 mm grains of orthopyroxene near the contact.

A300-107 appears slightly different in the field but in: thin section exhibits a similar although coarser texture: It does not possess the clumps seen in the finer grained dykes. 
IV STRUCTURE 


\section{Layering and Folding (Country Rock)}

Except for a small, much faulted area just north of the western lobe, the attitude of the layering is very constant, dipping $40^{\circ} \mathrm{N}$ and striking roughly E-W. Significantly, perhaps, this attitude remains the same right up to the contact with the intrusion, and this contact is markedly nonconformable to the layering.

The country rock in the mapped area forms the northern limb of an antiformal macrofold whose fold axis trends E-W and which closes S-E of the area investigated. Some mesofolds of similar style were observed and in a few cases exhibited a structure resembling cross-bedding on one limb (Plate 7 ). This latter feature may result from axial plane slip. In one locality, irregular plastic folding was observed.

\section{Faulting}

\section{(a) General}

The general appearance of the country rock is one of local crustal movement. This is expressed in the western areas by numerous shears and faults, and in the eastern areas by a few clearly defined shears and strong crustal disturbances whose precise movements are difficult to establish.

(b) Pre-metamorphic Faulting.

In the $S-W$ corner of the area, two instances were observed in which discordant layerings in the country rock abutted one another. : The only evidence of faulting in one was observed slickensides in the fault plane. The other instance showed 
convincing evidence of bands being pulled into concordance with the fault plane. A finely banded dark granulite marked the fault and this may have been a metamorphosed dyke.

These faults bear no apparent relationship to other tectonic features in the area and are interpreted, tentatively, as pre-metamorphic.

\section{(c) Major Shear}

The southern margin of the eastern lobe is a crush zone* which extends. into the body in line with a prominent shear through the country rock. Together they form a major lineament.

Specimen A301-64 from the crush zone reveals the rock to be strongly granulated and criss-crossed with numerous irregular fractures. Significantly, there is no suggestion of any differential movement within the rock, which seems to indicate a lack of shearing. However, the country rock immediately below this crush zone and running parallel to it, is a strongly mylonitized quartz-rich layer (described before), and in the shear west of the body greatly stretched augen are pulled out in the shear direction. Possibly, therefore, the country rock has been subjected to shearing along this zone for a much longer time or during much more severe tectonism than has the intrusion. On the other hand, the difference in physical properties (elasticity, brittleness) between the country rock and intrusive rock, may cause a different texture to form.from the one shearing movement. Perhaps the body was 
emplaced along this shear during its last active phase and the magma solidified just before activity ceased. Thus the crushing in the body would have occurred during the final stages of tectonism along this shear so that no differential movement is expressed in the rock fabric.

(d) Gabbroic Dykes

Mineral composition and texture show that the Upper Layer and the Giles dykes are petrologically similar and probably were emplaced from a common source. The constant shallow dip of these dykes suggests that the fissures along which they intruded may, in fact, be a set of thrust planes. It is to be noted that these dykes strike perpendicular to the crush zone.

(e) Younger Dykes and Shears

A swarm of dykes and shears can be seen striking in a general E.N.E.-W.S.W. direction across the area. They are genetically distinct from and younger in age than the Giles dykes and major E-W shear. These dykes dip steeply south $\left(50^{\circ}-60^{\circ}\right)$ and their texture, unlike the Giles dykes, is that of a dolerite. They intrude, and therefore post-date, both the Giles Complex rocks and country rock.

In many cases, the dykes grade into shears and it appears that movement often continued after emplacement and solidification of the dolerite.

In an isolated hill of country rock south of the main intrusion, some of these younger dykes have been dissected by 
later shears with resultant slickensiding on quartz-rich (characteristically blue) layers. Brecciation is observed occasionally.

Specimen A300-130, from a sheared dyke, exhibits curved fault planes, as illustrated below (fig. 18 ).

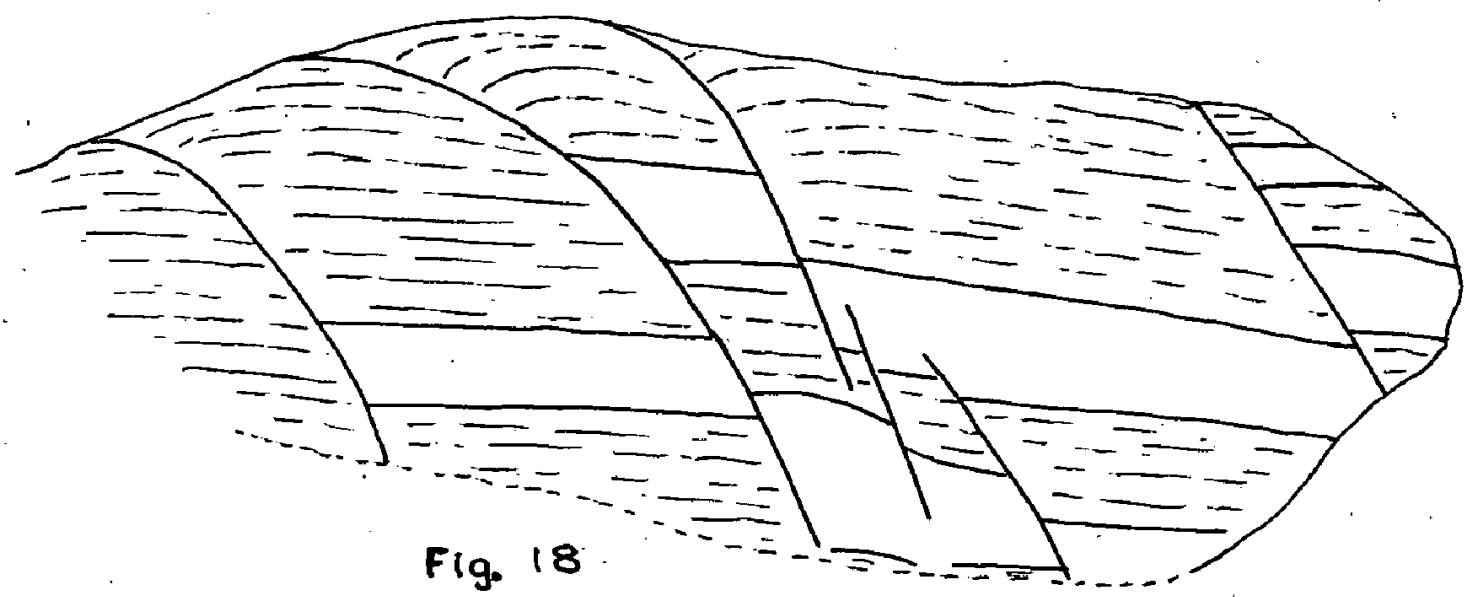

These sets of dyke-shears appear in general to give little or negligible displacement, but to the $N-W$ of the body, a concentrated set of shears has caused considerable disturbance and displacement.

3. Deformation: Textures and Their Significance

Deformation of the whole area - both country rock and the intrusive rock - is expressed very commonly in thin section. Undulose extinction is usual for the majority of minerals, glide twinning in plagioclase is common and quartz grains often display dislocation boundaries.

(a) Kink Banding

Orthopyroxenes from the main intrusion commonly show gradations from broadly curved cleavages to locally distorted cleavage to sharp kink banding (Plate 31 ).

L.E. Weiss has suggested (personal communication) on 
theoretical grounds coupled with observation, that the kink lamellae are not parallel, but that adjacent lamellae are slightly oblique to one another. This has been observed in specimens from Ewarara (Plate 31). Angles of inclination up to about $5^{\circ}$ are usual. The kink iamellae are approximately normal to the crystallographic c-axis of the bronzites, the c-axis commonly being at about $80^{\circ}$ to the kink plane. Kink planes are usually about $0.3 \mathrm{~mm}$ apart. These geometric relations are illustrated below (fig. 19).

Similar relationships are observed commonly in olivine (Plate 34) and also in coarse biotites.

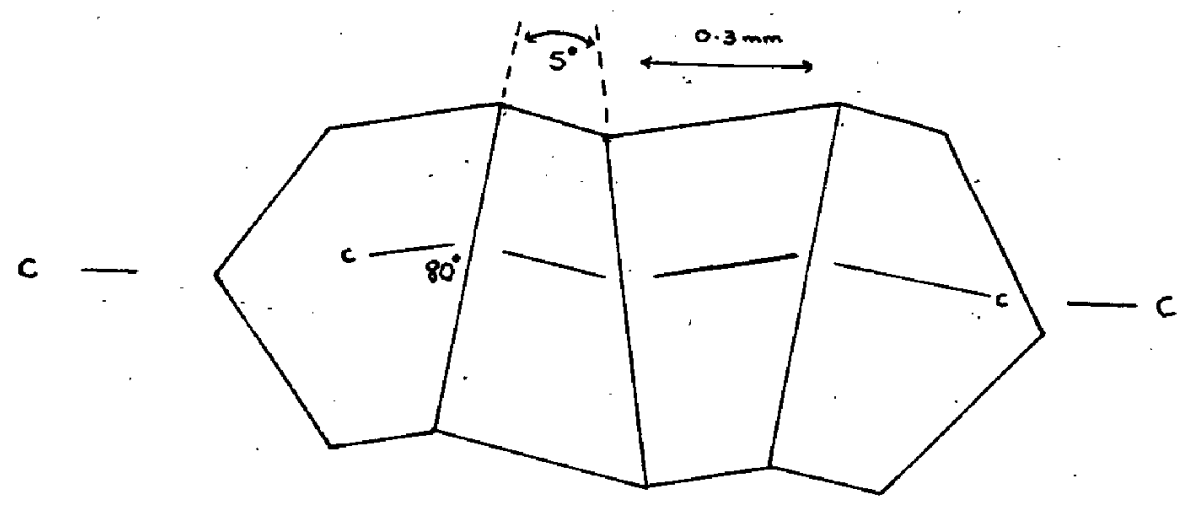

fig 19

In the bronzites, some kink planes are flanked by inclusions (spinel ?) slightly coarser than usual and which are separated by a barren zone from the usual fine oriented inclusions. Fig. 20 below shows this relationship.

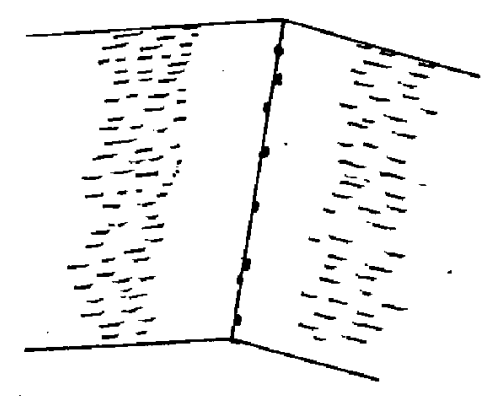


A similar occurrence is sometimes noted at grain boundaries (fig. 10a). This suggests that these inclusions, caused by exsolution may have either migrated to or coalesced at these localized positions, or even that their exsolution may have been triggered by the tectonic strains which caused the kinking. Occasionally, large fractured bronzites occur. Possibly, these are formed by continued mechanical deformation after kinking, breakup occurring along the kink planes (Plate 33 ). Orientation of kink planes.

Evidently, the kinking of the pyroxenes was caused by a directed stress, as only those grains in a particular crystallographic orientation are kinked. 'Some preliminary work has been done to put this on a quantitative basis. A flat stage microscope was used to record the orientation of the trace each kink plane made with the plane of thin section. Two specimens were examined, and allowing one count per grain, the results for each were plotted as a rose diagram at $5^{\circ}$ intervals (fig. 2l). In both cases (and especially for A300-125 which provided the much larger number of counts) a pronounced maximum is evident indicating a strong preferred orientation of kink planes within each thin section despite the isotropic arrangement of grains. Very likely, a similar preferred orientation of kink planes exists for the intrusion as a whole but oriented specimens from various parts of the body have not yet been collected to verify this interesting possibility. Quite probably, the direction of kinking is 


\section{Fig. 21}

Orientation of kink lamellae.

1. Pronounced maxima - left to right - (and the minima perpendicular to the maxima) are observed in both cases.

2. A301-61 and A300-125 are not oriented specimens and so these diagrams are not geographically oriented. . They merely show that maxima exist in both cases.

3. Scale: $A 301-611 \mathrm{~cm}$ radius $=1$ count $A 300-125 \cdot \frac{1}{2} \mathrm{~cm}$ radius $=1$ count

4. The superimposed circles indicate the expected frequency per $5^{\circ}$ sector for a 2-dimensional isotropic model. Their radii are calculated from the 37 counts made from A301-61 and the 93 counts from A300-125. 


\section{A 301-61}

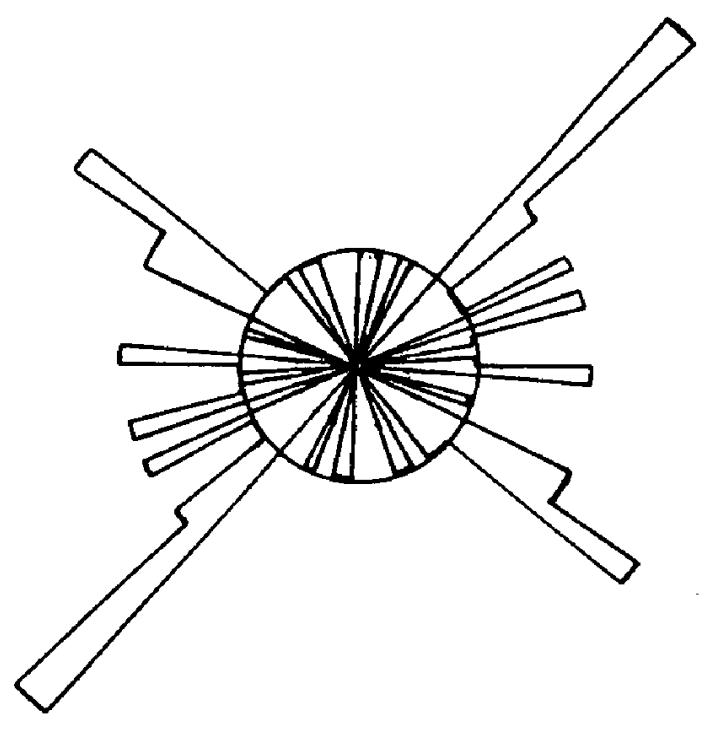

A $300-125$

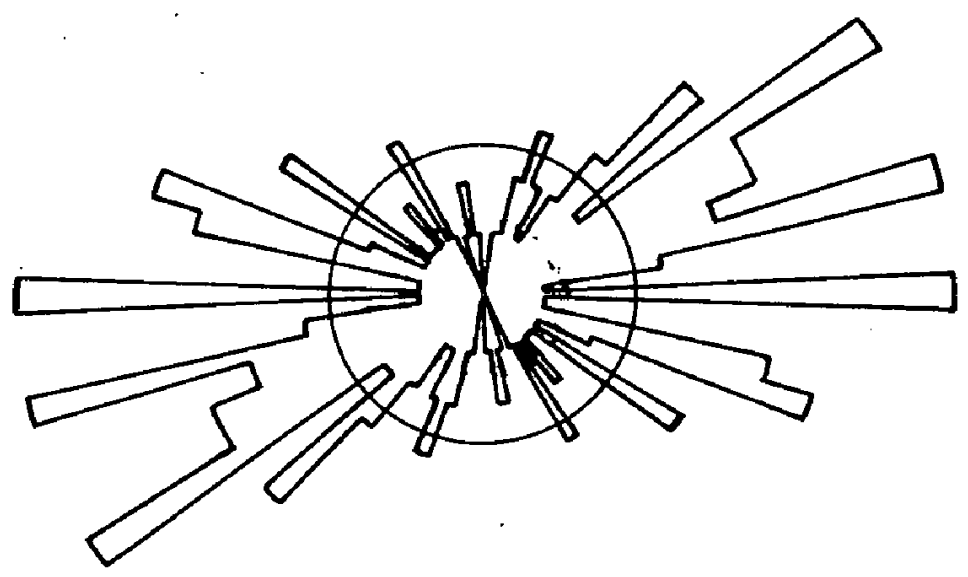


allied to that of the other tectonic features.

(b) Cataclasite Texture

On close examination of thin sections, the opinion has been formed that stresses, when applied gradually over a long period may, instead of kinking the pyroxenes, cause a partial physical breakdown of them. Various stages may be recognised:

(1) Initial breakup of the phenocryst at the crystal edges.

(2) Complete granulation of the whole crystal with little movement of grains (Plate 35 ).

(3) Formation of "fingerprint" patterns by the granules (Plate 36).

(4) Complete physical breakup into a disordered array of grains which helps form the matrix commonly seen interstitial to the phenocrysts.

The process is not well enough understood to place any reliance on the time significance of the above stages or possible variations depending on individual conditions.

(c) Hourglass Zoning

This zoning, in contrast to the described chemical zoning, possibly may develop in response to a stress field applied during exsolution on cooling. Thus, spinel would exsolve more thickly in some areas than in others. Though purely speculative, some tectonic explanation seems necessary to explain their shape. It may not be related to and may have occurred earlier than the E.N.E.-W.S.W. shearing previously mentioned. 
4. Other Structural Features (Intrusion)

The main structural features of Ewarara are summarized diagrammatically in fig. 22 .

(a) Layering and Associated Textures

Generally, layering is confined to specific horizons in the main intrusion, and usually is defined by differential weathering of the rock into bands and pitted horizons. The layering appears to have two general attitudes, one shallowdipping and the other essentially vertical. Only one of the minor intrusions (A300-77) exhibits layering although a flow texture occurs in A301-153. A more detailed investigation is required but some preliminary observations are presented below. (i) Shallow-dipping Layering (A300-102)

This banding dips up to about $30^{\circ}$ and appears to be roughly concordant with the contact (Plate 5). Isolated higher dips (up to $55^{\circ}$ ) are probably caused by later disturbance. Layering is defined by coarse grained bands and these are clearly distinguishable from the adjacent rock. Further investigation may reveal a chemical variation as well. Bands are a few centimetres in width and may extend for some tens of feet, or else they form as lenticular sheets and segregations. These coarse layers may contain pyroxenes up to $15^{\circ} \mathrm{mm}$ long and the orientation of pyroxenes is shown diagrammatically in fig. 23 , below. 


\section{DIAGRAMMATIC STRUCTURAL IN TERPRE TATION}

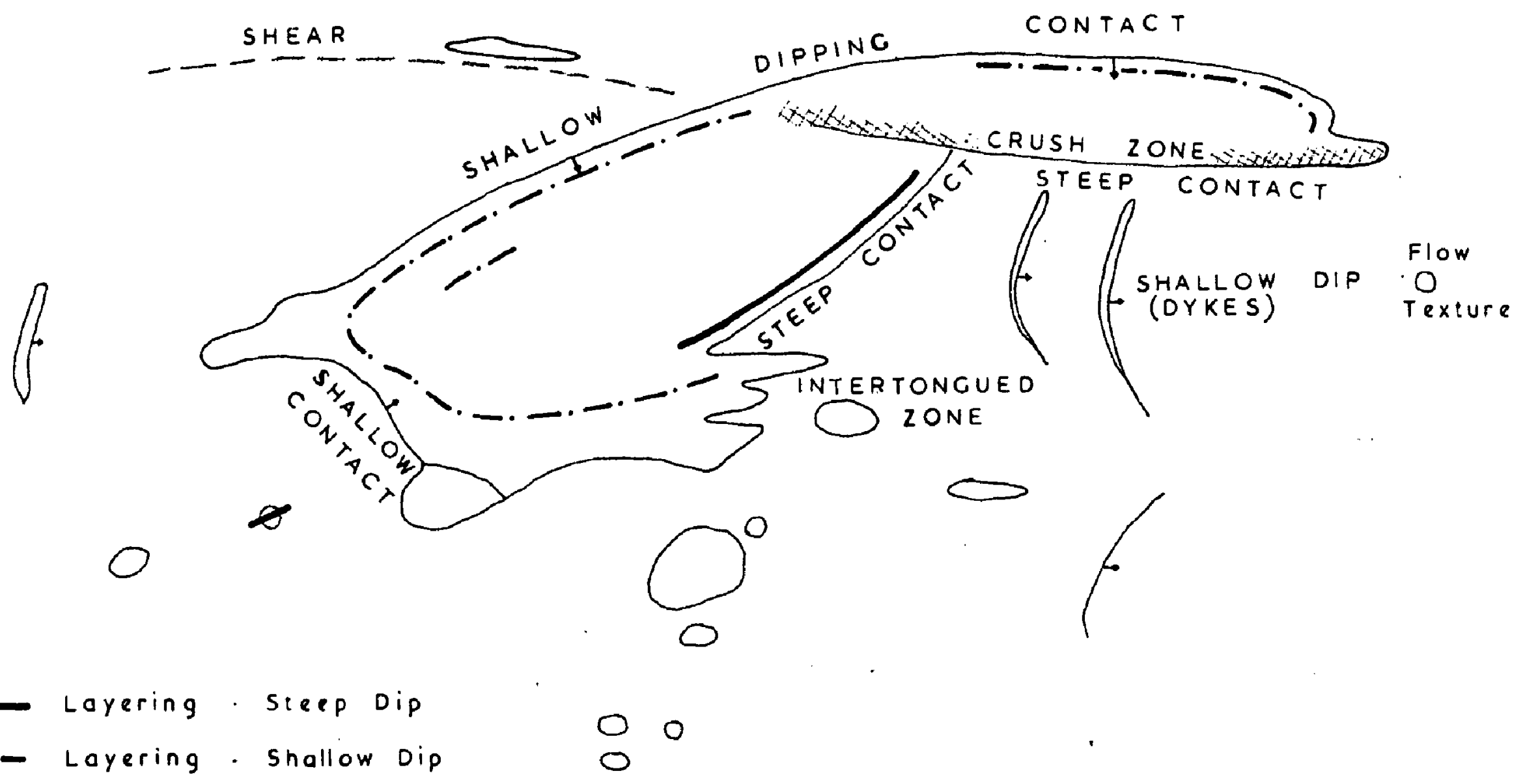




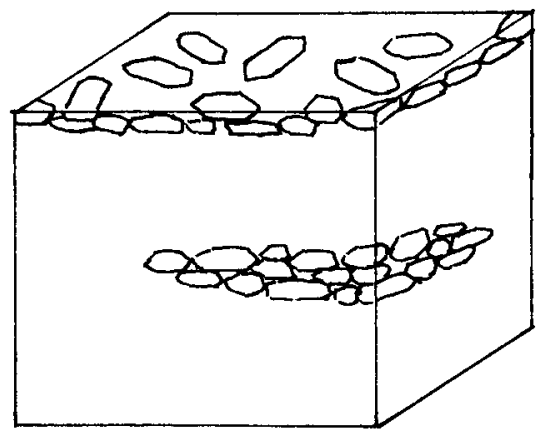

\section{Fig 23}

The bronzites form a self-supporting structure witn plagioclase Interstitial. st the poundary interiaces to layers the tiner grainea material packs into the coarser grains. I'his is somewhat similar to the cusp texture observed in the ultrabasic zone of stillwater lomplex (Jackson, 1961).

\section{(ii) vertical Layering}

vertical layering was observed in a single norizon near the south-eastern contact of the main lobe (rlate $\sigma$ ). West of the intertongued area, the horizon was not located, but steep banding was observed along strike in a small plug to the west. Ihe scale and texture of these bands are similar to those described above. A band in $4500-12$ contains coarse, aark coloured bronzites with some olivine and plagioclase. I'he neighbouring layers contain tiner grained and lighter coloured bronzites and plagioclase. Both bronzites are zoned. (iii) "iryptic" Layering vensity variations across the body (fig. 24) nave been shown to be paralleled by variations in the modal plagioclase (I'able 2) and presumably not by a marked chemical change. Protiles are similar for various traverses and probably represent a macroscopic 
Fig. 24

Denaity profiles for "Tip-Heap" Traverse (A), Camp Traverse (B) and Gash Traverse (C); compared with variation in modal plagioclase for "Tip-Heap" Traverse.

A300-91, 92a, 113, 127, 128 are olivine pyroxenite samples; remainder are pyroxenite samples. 


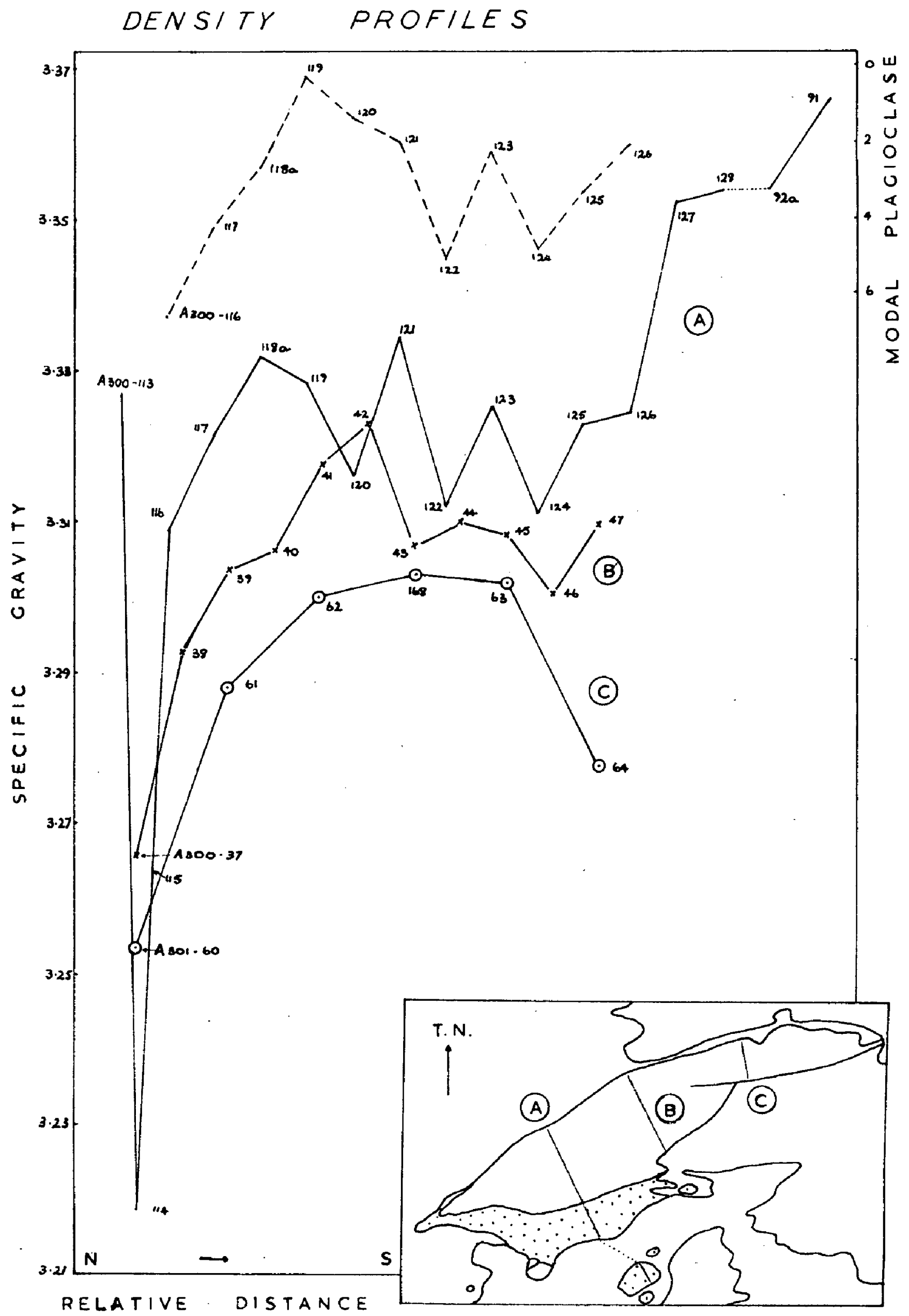


layering in the pyroxenlte not apparent in the riela. Mecnanlsm of tormation of layering.

l'ne alstribution, orientation and petrologlcal nature of the low-aipping layering strongly suggests gravitational settling of crystals on to a gently undulatory surtace, possibly basin-like.

I'ne vertical layering on structural evidence does not appear to be an inverted or folded Iorm of the gravitational layering. 'lentatively, it is thought to have been formed by ditierential viscous flow along a near vertical plane (the southern contact). similar layering is not observed in the equivalent position of the eastern lobe, but post-crystallizational crushing may have obscured any such layering. This mechanism has been proposed by wilshire (1901) for the layering of diatremes in N.S.W.

There is some evidence for current action and viscous tlow in various parts of the magma. In several instances rod-like pyroxenes up to $10-\measuredangle 0 \mathrm{~mm}$ long are strongly aligned to give lineated textures, and, as described earlier, As01-15, displays a marked alignment of coarse plagioclase laths, suggesting a flow texture.

(b) "shadow" Lone Lxtending the full width of the body at its western end and into the country rock on the northern side a zone of fiour banas appear on aerial photographs as low "welts". H'ield investigation shows nothing more than low depressions. It is telt that this 
feature may be a structural effect - large scale jointing, perhaps - although such an explanation is speculative. These "welts" are perpendicular to the strike of the other layering. 5. Gravity Profile

The kind co-operation of the s.A. Lept. of Mines enabled a traverse of 27 stations at 300 it. intervals to be made obliquely across the western lobe. from elevation measurements, accurate to $0.1 \mathrm{ft}$, corrections were made on the observed gravity results assuming a density of $3.1 \mathrm{gr} / \mathrm{cc}$ and an arbitary datum of $100 \mathrm{ft}$. (fiig. 25 ). Bouguet and terrain corrections were not calculated because of the lack of established surveyed points.

Interpretation.

A density of $3.3 \mathrm{gm} / \mathrm{cc}$ for the intrusive rocks and $2.7 \mathrm{gm} / \mathrm{cc}$ for the country rock was assumed.

On calculation, a stock like intrusive mass gives a gravity anomaly about six times the onserved 2.5 milligal anomaly. On the other hand, a tabular body with a vertical thickness of 350 to 500 it. gives the required anomaly it a density contrast of 0.4 to $0.0 \mathrm{gr} / \mathrm{cc}$ is assumed. This agrees with field information on the western contact from which the body is interpreted as a sheetlike mass (tig. 26).

The gravity protile does not extend far enough for any definite picture of the eastern contact to be inferred. West of the contact near $X$, gravity values for the country rock appear to increase anomalously. However, the density of 


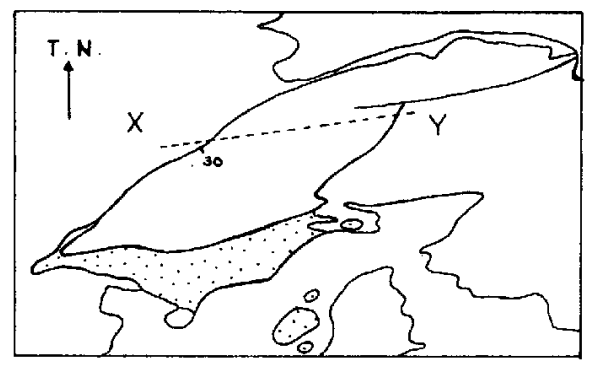

$Y$ located at $26^{\circ} 4^{\prime} 5^{\circ} \mathrm{S}$ Section line $255^{\circ} 50^{\circ} 00^{\prime \prime} \mathrm{T}$ from $Y$

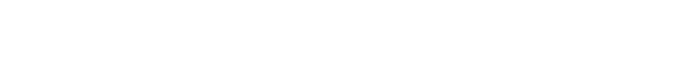

Cravity (Elevotion corrected)

3 Topography (Notural Scale)

4 Topography (vertical 10x)

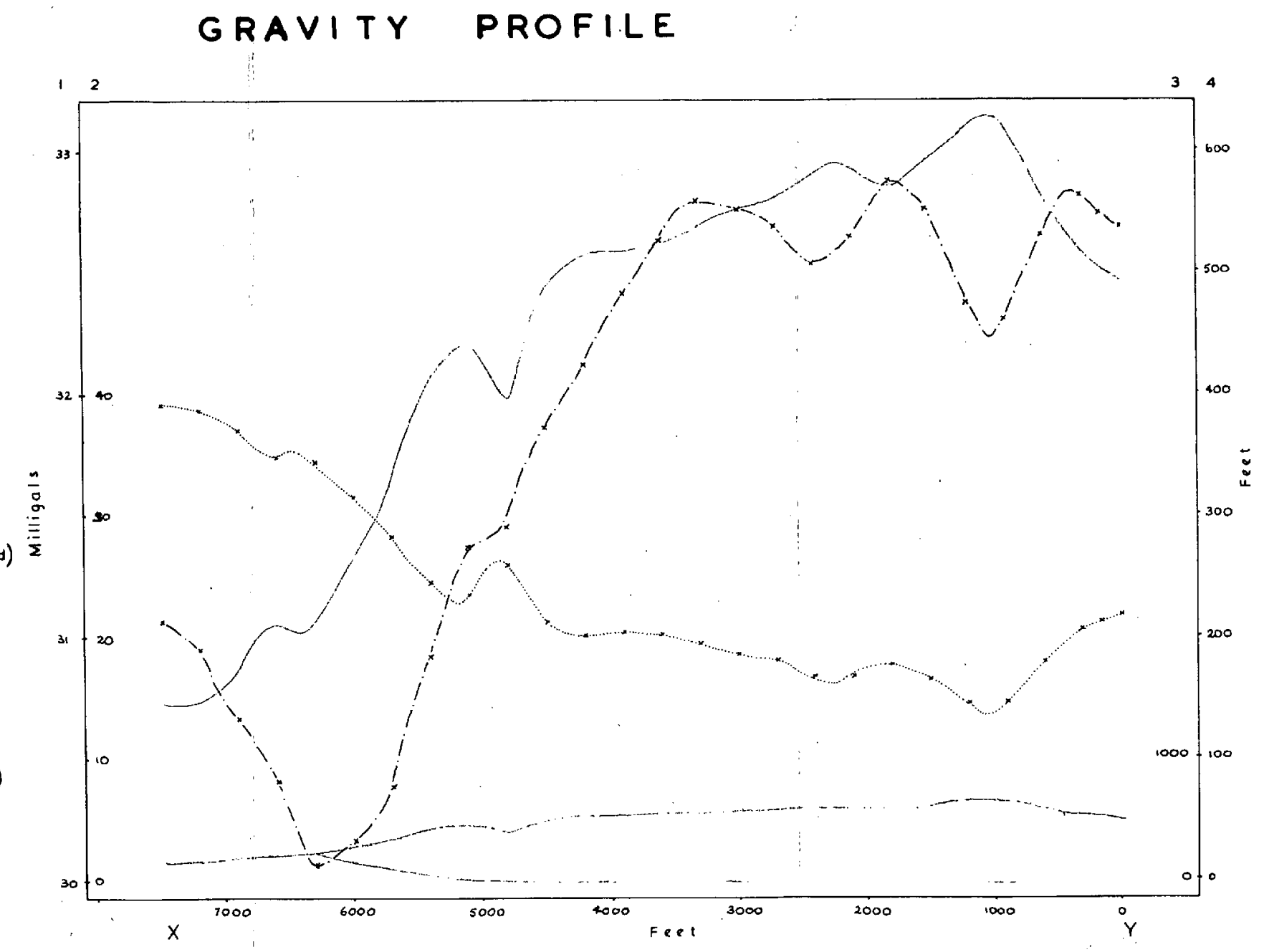




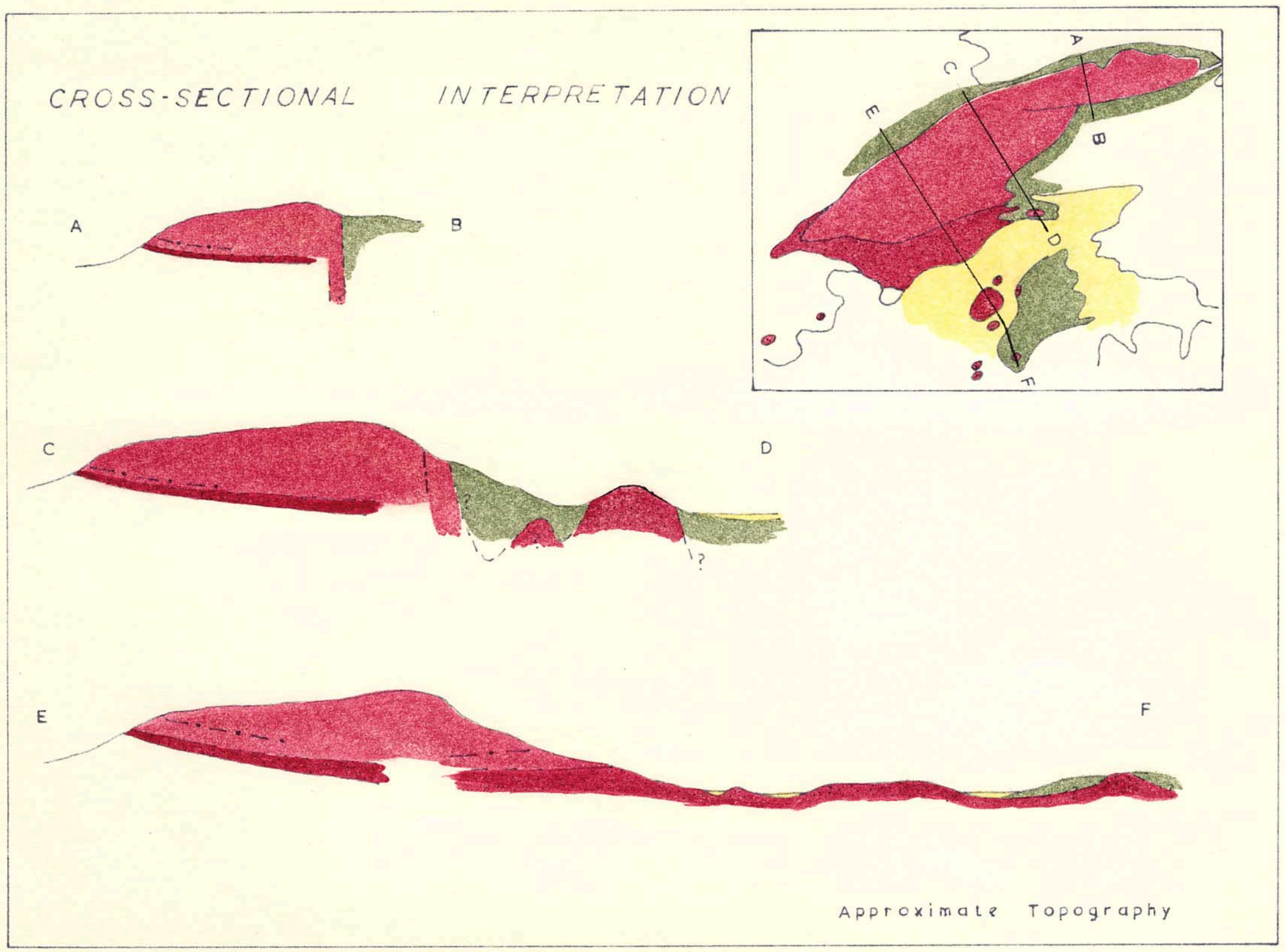

$\pi$
$\pi$
$\alpha$ 
country rock $(2.7 \mathrm{gr} / \mathrm{cc})$ is lower than that assumed $(3.1 \mathrm{gr} / \mathrm{cc})$ in calculating the gravity profile, andthe attraction of the neighbouring mass of itwarara was ignored. These factors may account for the high values.

similarly, wrong density corrections may have been responsible for the oscillations in the profile plateau near the eastern contact.

6. Shape of the Intrusions

(a) Main Body

The following interpretation is based on field observation. petrological evidence and the gravity profile (Iigs. 25,26). To facilitate discussion the body has been divided into zones $(f i g \cdot 27)$

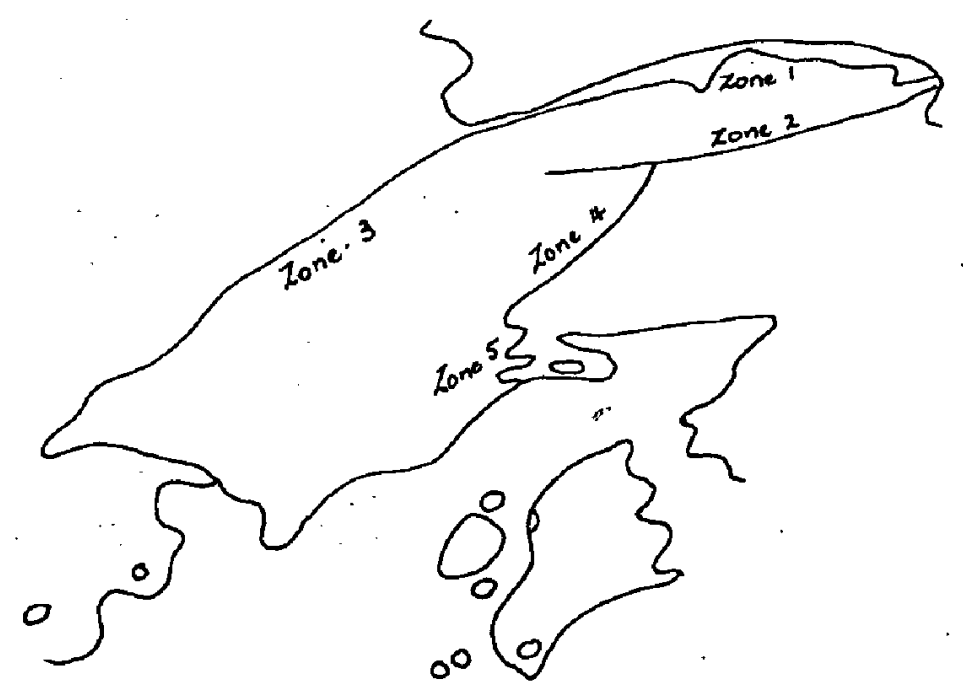

Fig 27

(i) Eastern Lobe

This lobe appears to be a lopolithic sheet with a shallow northern contact (zone 1) and a steep southern contact, perhaps vertical (zone 2). This steep contact coincides with a crush 
zone presumably a continuation of the large shear to the west.

A slight topographic rise gives a physical boundary between the eastern and western lobes.

(ii) Western Lobe

Lones 3 and 4 are similar to the above zones, and presumably the body can be represented by a flat or shallowdipping sheet abutting a steep southern contact.

The south-west corner of the intrusion becomes more complex. The intertongued zone $b$ probably has steep dipping contacts similar to zone 4. The extent of the eastward continuation of these tongues under the granulite is not known.

several low-lying outcrops of olivine pyroxenite south of the body are assumed to be continuous with the body. Although contacts were observed between these and the granulite, no qualitative observations of their attitude could be made. It is thought that these outcrops are exposed parts of a thin (?) flat-lying lens of olivine pyroxenite south of the intertongued zone. The granulite (represented at F, fig. 26) Iorms the upper contact to this sheet but not to the main part of the intrusion shown by zones 1 - 4. H'ield observation suggests that the roof was rather irregular. A500-67 probably represents a shallow cupola.

Possibly, the steep contact in zone 4 continues in the same line under this lenticular sheet.

The relationship of the small pyroxenite outcrop (A300-81a) in the south-west corner of the intrusion to the rest of the 
intrusion is not known.

(b) Other Intrusions

(i) $\quad$ As00-7\%

This is, most probably, two small plugs with steep contacts. It may represent the outcrop of two pipe-like masses.

(ii) HSOO-79

This may be similar in nature to ASOO-\%.

(iii) AS01-1bS

Wo contacts were observed in this body but it may be a pipe-like inass. This is substantiated by the fllow texture it exhibits.

(iv) A301-175, 190

These have lenticular outcrop patterns but their vertical extent is not known. They do not appear to be flat-lying. (v) As00-105 (Anorthosite)

The anorthosite appears to be a thin sheet-like intrusion, closely associated with the steeply dipping shear. Movement on the shear appears to have continued after and possibly during intrusion.

(vi) Gabbroic Dykes

These thin shallow-dipping sheet-like intrusions have been mentioned before. They are not physically continuous with the main body in surface outcrop. The reason why the country rock separating them from the eastern lobe is unfavourable for the injection of dykes, is not certain, but its strongly compressed nature may be a significant factor. 
V.. $\quad$ CONCLUSIONS 
1. Shape of Ewarara Intrusion.

Ewarara Intrusion is a layered ultrabasic igneous body; about $3 \frac{1}{2}$ miles long by 1 mile wide, and showing a visible stratigraphic thickness of 500 to 600 feet. The intrusion, from field and gravity observations, can be considered as essentially a flat or shallow southerly dipping sheet abutting a steep southern contact. In the south west corner of the area, this flat sheet could extend as a thin lens to the south.

It consists of two major layers - a lower olivine pyroxenite layer and an upper pyroxenite layer.

2. Evolution of the body.

(1) Magma was probably injected into the chamber along the steep southern contact through dykes and/or pipes. In the eastern lobe this injection is associated with a large shear (further to the west, an anorthosite is intruded along the same shear).

(2) Contamination at the margins of the body is indicated by the usually hybrid nature of the contacts, and the presence of biotite.

(3) Crystal settling from the magma produced both major layers, the primary precipitates being spinel, olivine, bronzite in the lower layer and augite, bronzite in the upper layer. Petrological and chemical evidence indicates a major break between the deposition of the layers.

(4) The interprecipitate materials of both layers are probably not related directly to the material they enclose. 
3. Differentiation in the body.

Whole rock analyses indicate a marked enrichment in $\Sigma \mathrm{Fe}$ relative to Mgo towards the top of the intrusion. A very low $\Sigma \mathrm{Fe} / \mathrm{MgO}$ ratio is similar to Mt. Davies Intrusion.

Orthopyroxenes show a cryptic variation in the body, becoming more iron rich towards the top. A marked break occurs between the. two major layers.

Plagioclases show an expected random variation in composition. 4. Formation of Banding.

(1) Shallow dipping layering is considered to be due to gravitational settling of crystals; minor and major layers probably represent varying degrees of change in physical conditions in the body. Current action is indicated occasionally by lineated textures.

(2) Vertical layering is tentatively suggested to be associated with viscous flow in a confined space.

5. Smaller Intrusions.

In general the smaller intrusions can be viewed as plagioclase rich variations of the two major rock types, and may represent less viscous portions of the magma.

6. Metamorphism and Folding.

It is considered that the metamorphism of the granulites of the country rock is associated with the folding of the area, and that both occurred before the intrusion of the magma. Both orthopyroxeneplagiocase and clinopyroxene-almandine (or transitional mixed) assemblages of the pyroxene granulite subfacies are observed for 
the various rock types. Some modification of the above assemblages have occurred near the intrusion where the presence of hornblende indicates appreciable quantities of water.

7. Dolerite Dykes.

The dolerite dykes are intruded after both metamorphism of the granulites and the intrusion of the body. Continued movements after crystalization sometimes results in their own deformation. These dyke-shears may be responsible for the kinking, hourglass zoning and cataclasite textures observed in pyroxenes in the intrusion. 


\section{ACKNOWLEDGEMENTS}

The authors are indebted. to Drs. R.W. Nesbitt, J.L. Talbot and R.I. Oliver, Mr. J. Biddle and other members of staff and to fellow research students of the Geology Department of the University of Adelaide for assistance with this project.

Thanks are also due to the Nuffield Foundation for financial support, and to the S.A. Mines Department for carrying out a gravity traverse. . Two chemical analyses were carried out by A.M.D.I. and by I. Lambert (Australian National University). 


\section{REFERENCES}

Amos, M.D. and Thomas, P.E., 1965 : Determination of aluminium in aqueous solution by atomic absorption spectrometry. Analytica Chimica Acta, 32, p. $139-147$.

Basedow, H., 1905 : Geological report on the country traversed by the S.A. Government Prospecting Expedition, 1903.

Trans. Roy. Soc. S. Austr., 22, p. $57-102$.

Brown, G.M., 1957 : Pyroxenes from early and middle stages of fractionation of Skaergaard Intrusion. Min. Mag., 31, p. $511-543$.

Deer, W.A., Howie, R.A. and Zussman, J., 1963.: Rock Forming Minerals (Vol. I, II). Longmans. de Waard, D., 1965 : Occurrence of garnet in granulite facies terrane of the Adirondack Highlands. Journ. Petrology, 6, p. $165-191$.

Heier, K.S. and Adams, J.A.S., 1963 : Concentration of radioactive elements in deep crustal material. Geochimica et Cosmochimica Acta, 29, no. 1, p. $53-62$. Hess, H.H., 1952 : Orthopyroxenes of the Bushveld type, ion substitutions, and changes in unit cell dimensions. Amer. Journ. Sci., Bowen Vol., p. 180.

Jackson, E.D., 1961 : Primary textures and mineral associations in the Ultramafic Zone of Stillwater Complex, Montana. U.S. Geol. Surv., Prof. Paper 358. 
Jaeger, J.C., 1964 : The value of measurements of density

in the study of dolerites.

Journ. Geol. Soc. Austr., 11, p. $133-140$.

Laniz, R.V., Stevens, R.E, and Norman, M.B., 1964 : Staining of

plagioclase feldspar and other minerals with F.D. and C. Red No. 2 U.S. Geol. Surv., Prof. Paper 501-B.

Nesbitt, R.W. and Kleeman, A.W., 1964 : Layered intrusions of the

Giles Complex, Central Australia.

Nature, 203, p. $391-393$.

Smith, J.R, and Yoder, H.S., 1956 : Variations in X-ray powder

diffraction patterns of plagioclase feldspars.

Amer. Min., 41, p. $632-647$.

Turner, F.J. and Verhoogen, J., 1960 : Igneous and metamorphic petrology, 2nd edition. McGraw-Hill.

Vance, J.A., 1961 : Polysynthetic twinning in plagioclase.

Amer. Min., 46, p. 1097 - 1119.

Vol1, G., 1960 : New work on petrofabrics.

L'pool and Manchr. Geol. Journ., 2, p. 503 - 567.

Wilshire, H.G., 1961 : Layered diatremes near Sydney, N.S.W. Journ. Geol., 69, p. $473-484$.

Yoder, H.S, and Sahama, T.G., 1957 : Olivine X-ray determinative curve.

Amer. Min., 42, p. $475-491$. 


\title{
THE GEOLOGY
}

\author{
of
}

\section{EWARARA INTRUSITON \\ I.}

GIEES COMPLEX; CENTRAL AUSTRALIA

by

A.D.T. GOODE, B.Sc: and G.W. KRIEG, B.Sc.

\section{APPENDIX "VOLUME}


EXPLANATION OF PLATES 


\section{PLATE 1}

Ewarara Intrusion from the N-W, showing position of lower. contact.

\section{PLATE 2}

Ewarara Intrusion showing distribution of "tip-heaps", looking N-W over the southern alluvial valley. 

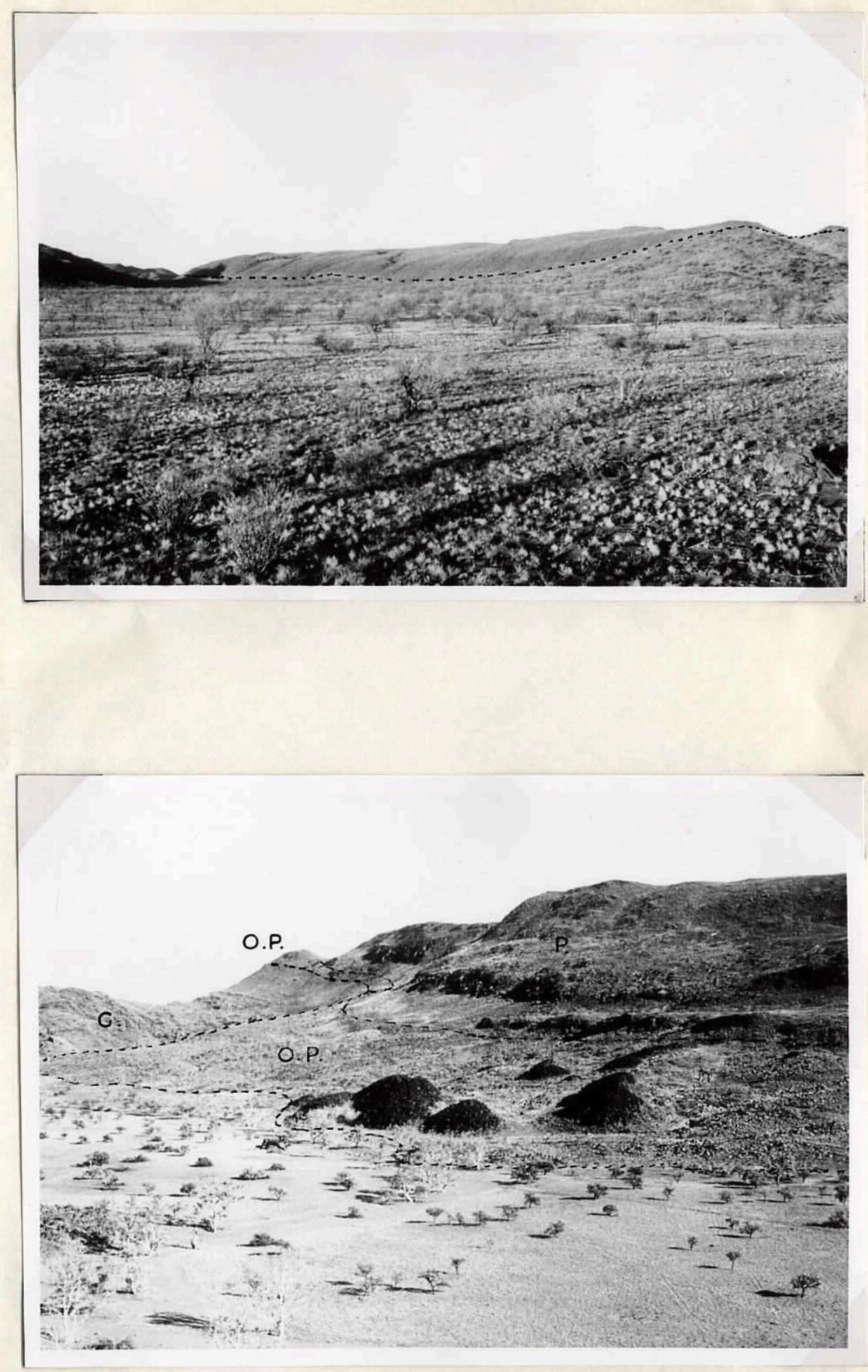
PLATES $3 \& 4$

Chilled contact of intrusive rock (dark) and granulite. 

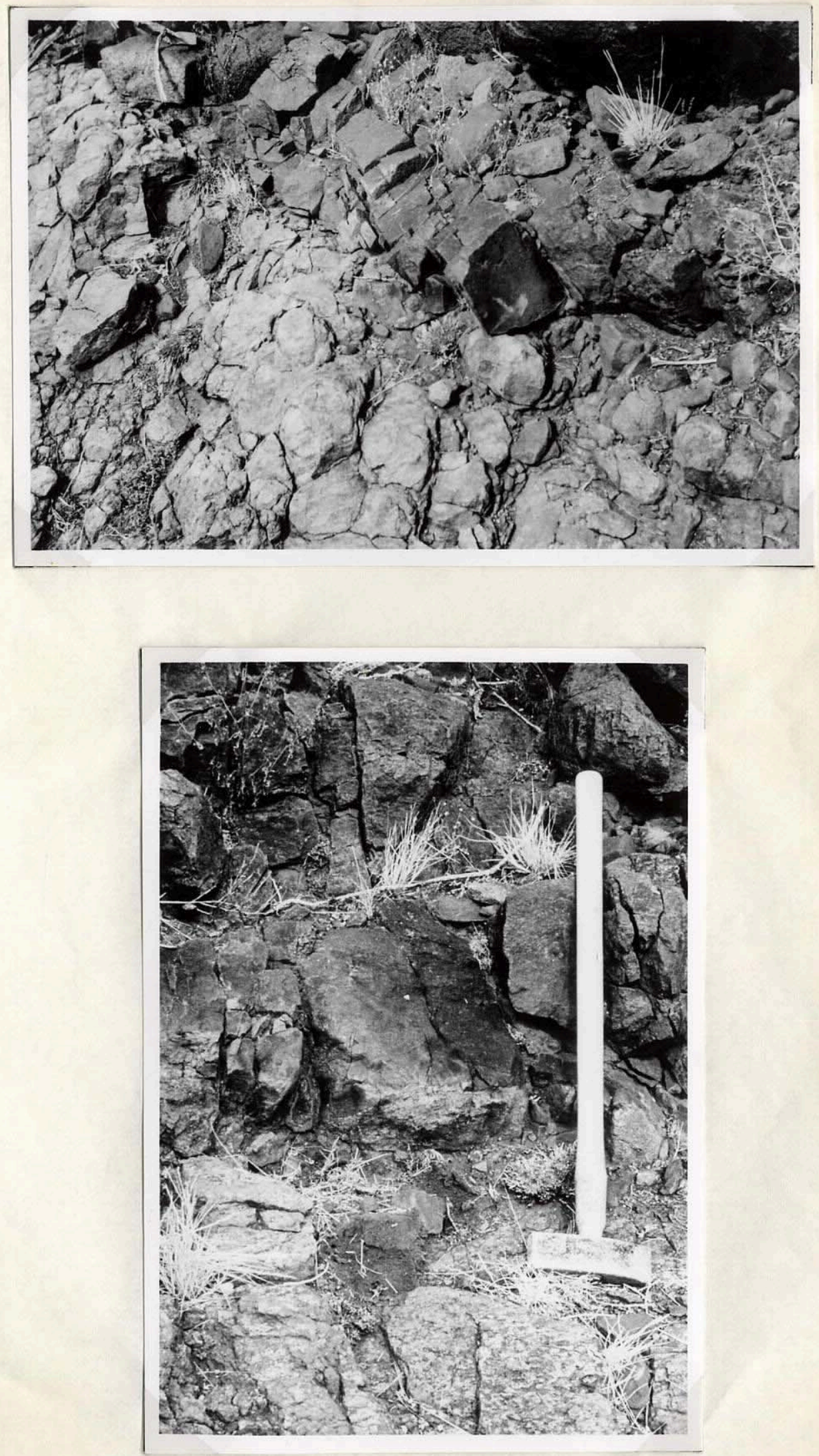


\section{PLATE 5}

Low dipping banding in Ewarara Intrusion.

\section{PLATE 6}

Vertical banding near southern contact, western lobe of intrusion: 

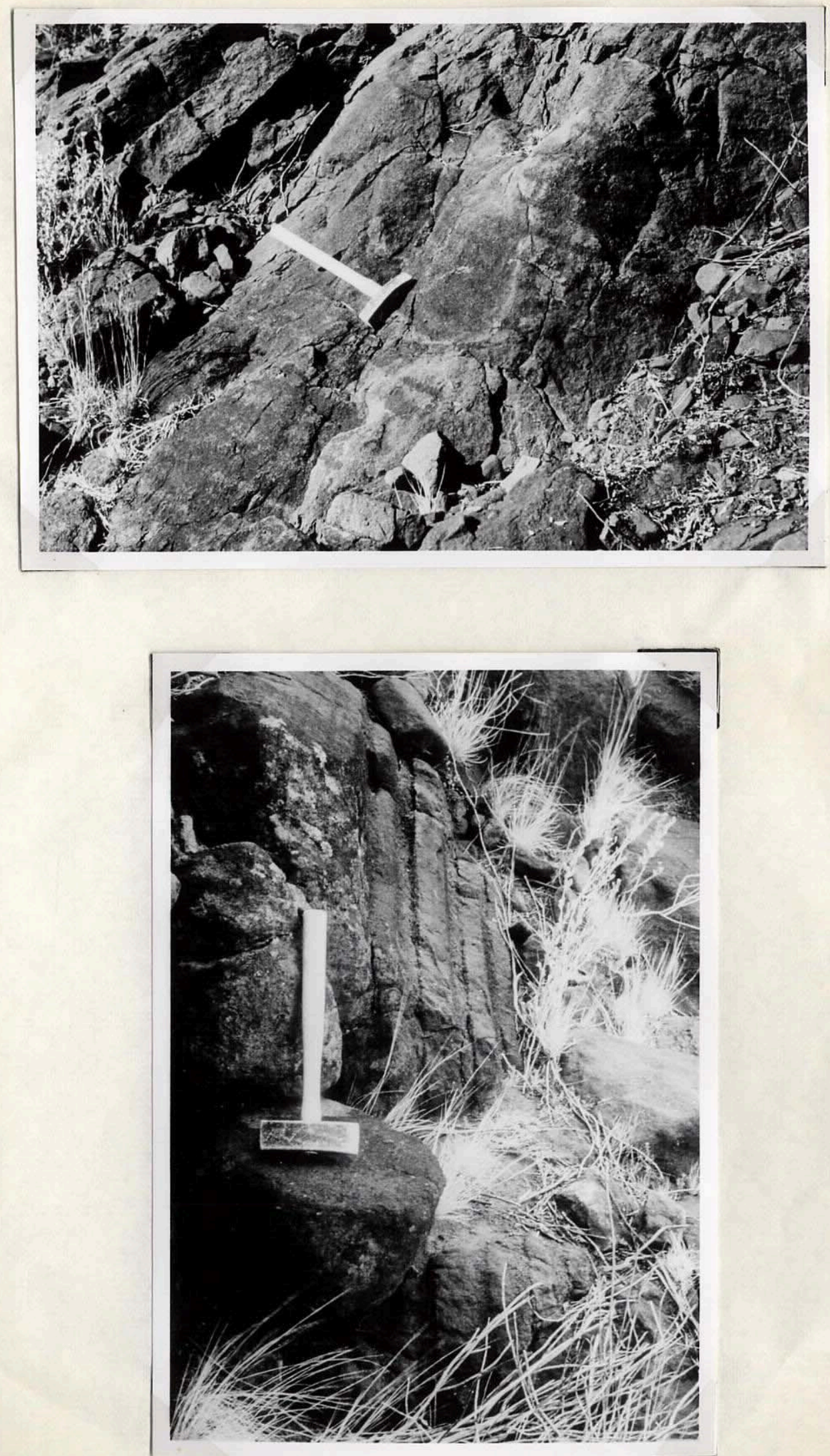


\section{PLATE 7}

Tight mesofold in granulite.

PLATE 8

Fine grained felsic vein discordant with granulite gneigs. 

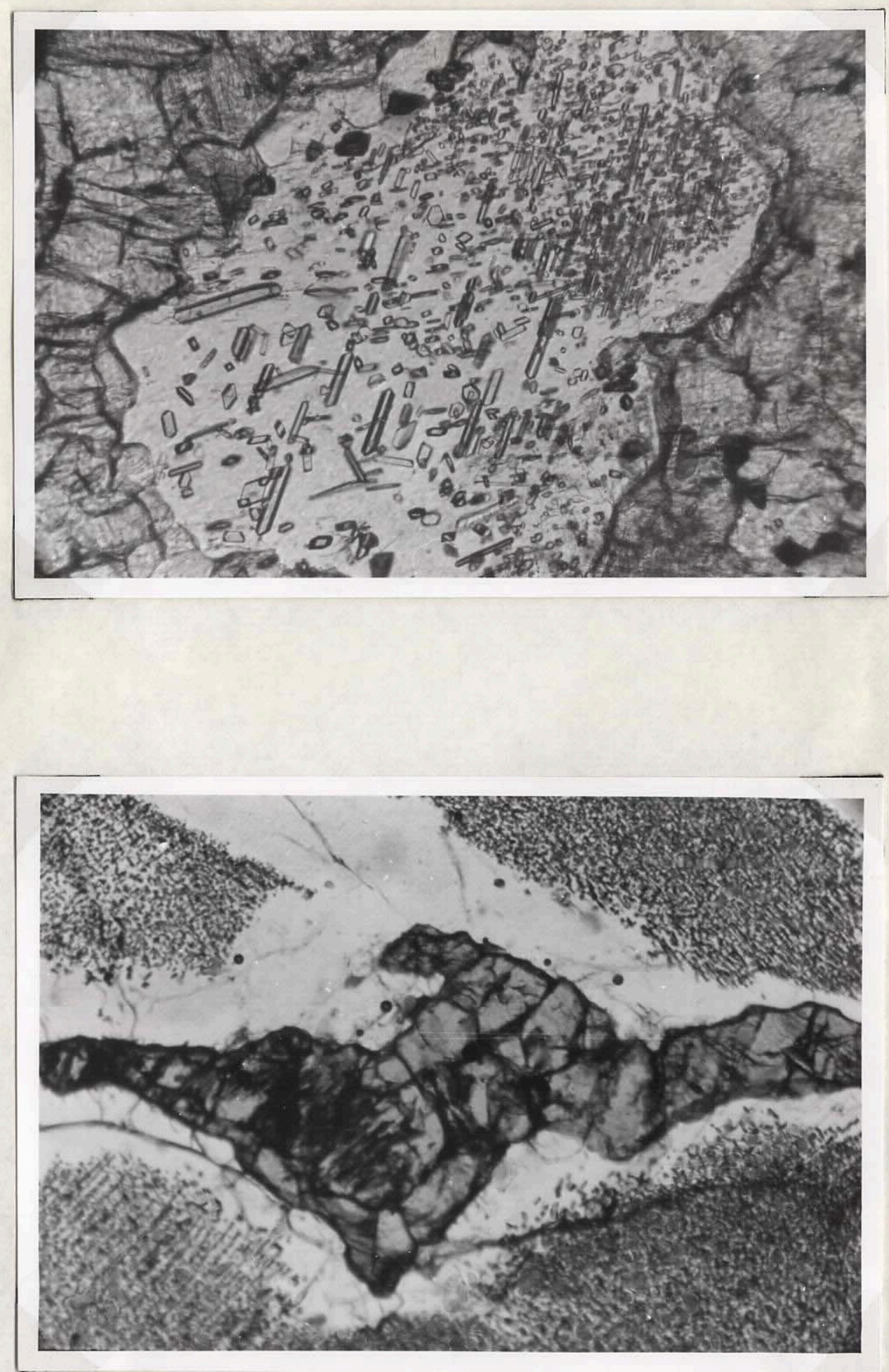


\section{PLATE 9}

Dark coloured "tip-heap!" of jumbled olivine pyroxenite boulders.

PEATE 10

Ridge marking crush zone and southern contact to eastern lobe. 

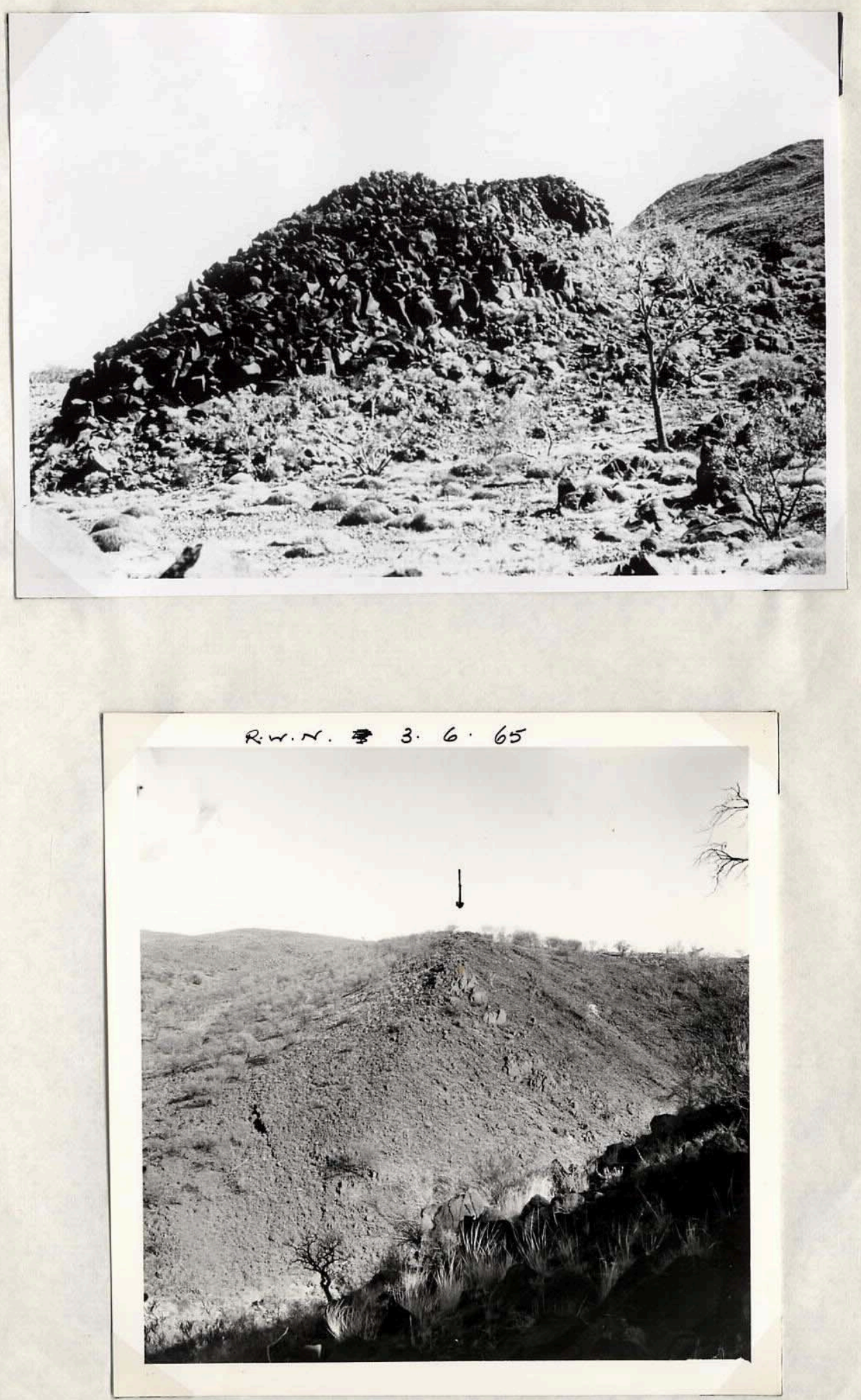


\section{PLATE 11}

Xenolithic material incorporated in mafic material; float near southern contact of eastern lobe.

\section{PLATE 12}

Hybrid contact between granulite and hornblende-pyroxenite (near A301-190). 

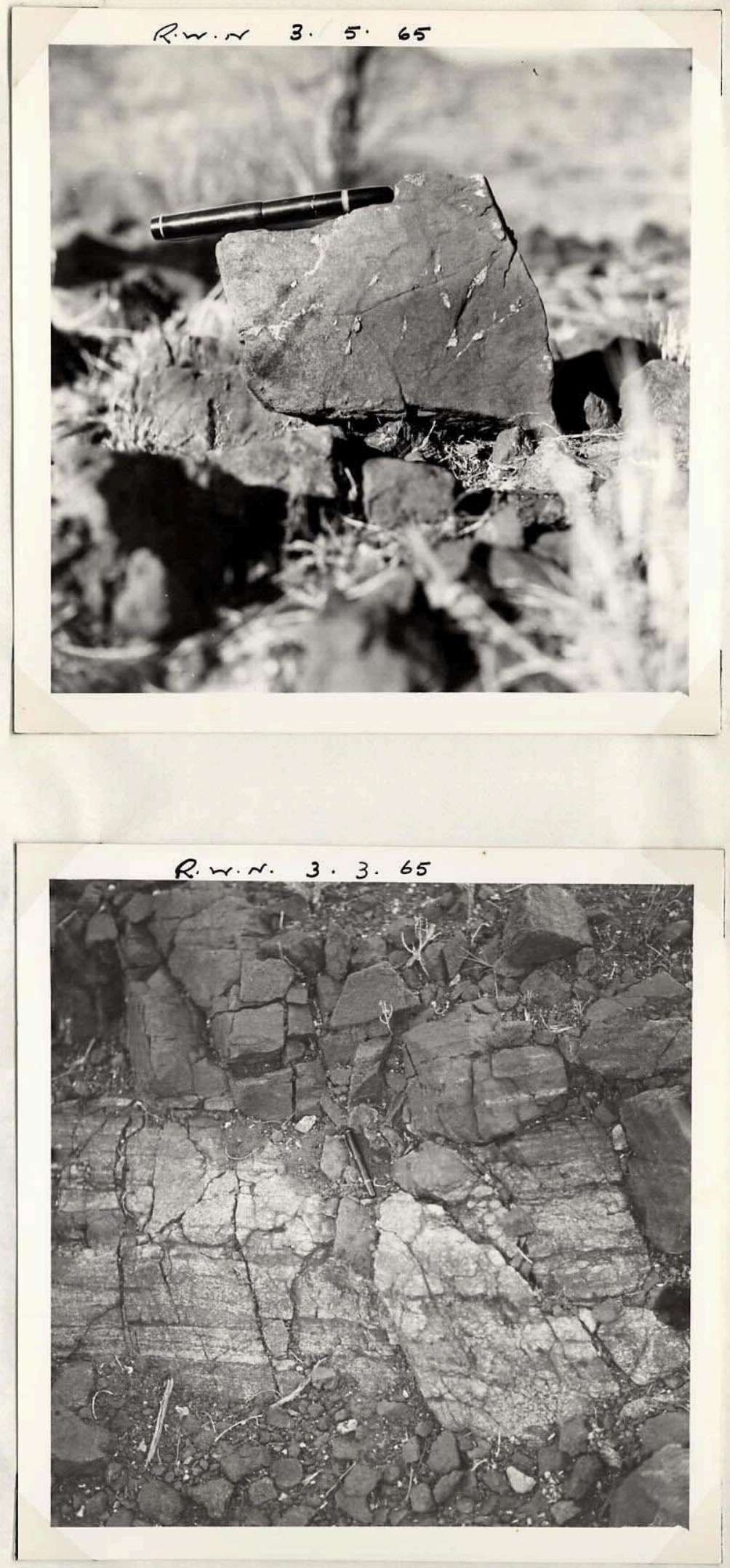


\section{PLATE 13}

Banding in granulite (middle distance).

PLATE 14

Augen gneiss. 

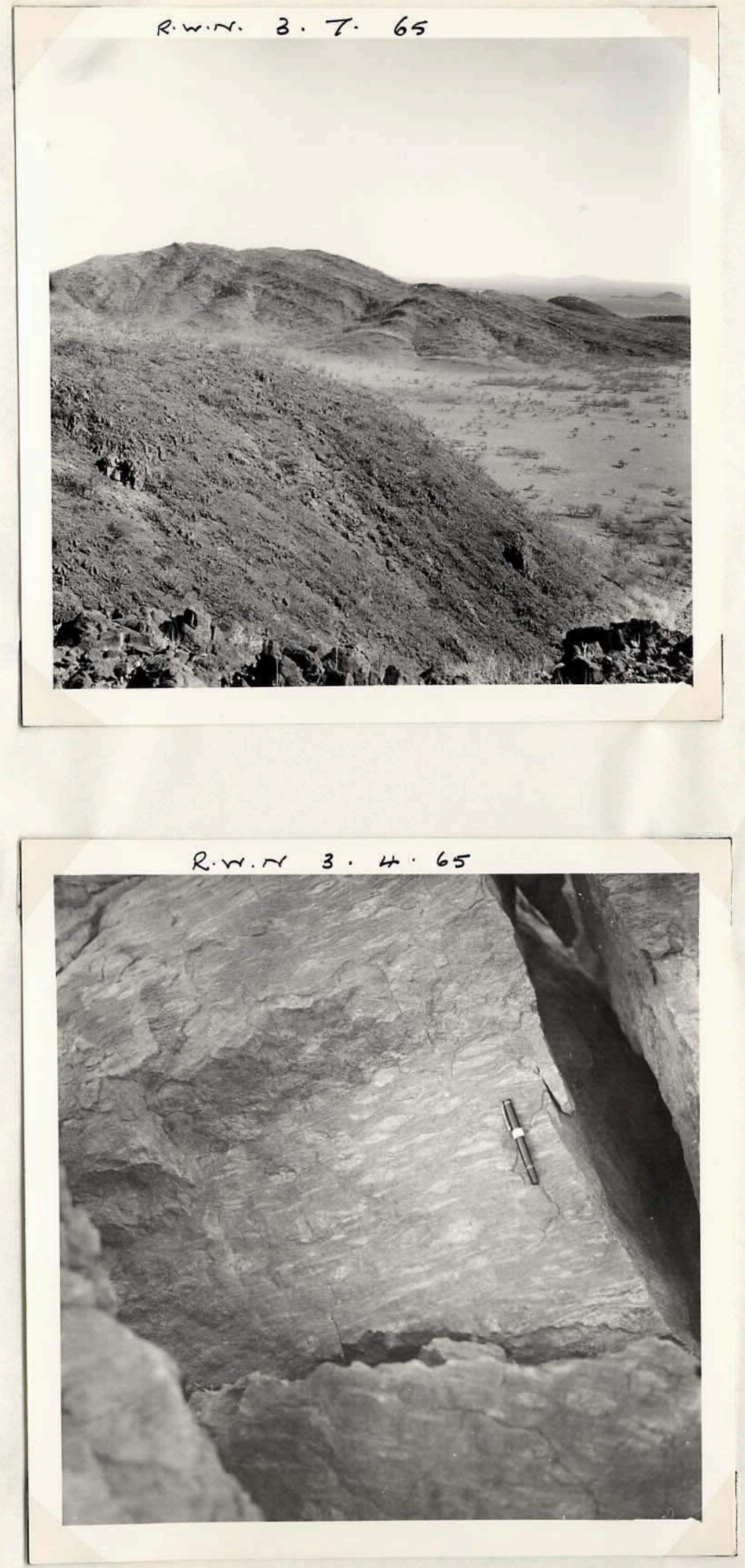
PLATE 15

Subhedral inclusions in plagioclase from granulite near contact $(x 800)$.

\section{PLATE 16}

Poikilitic plagioclase with subhedral inclusions of pyroxene, contact zone ( $x$ 50). 

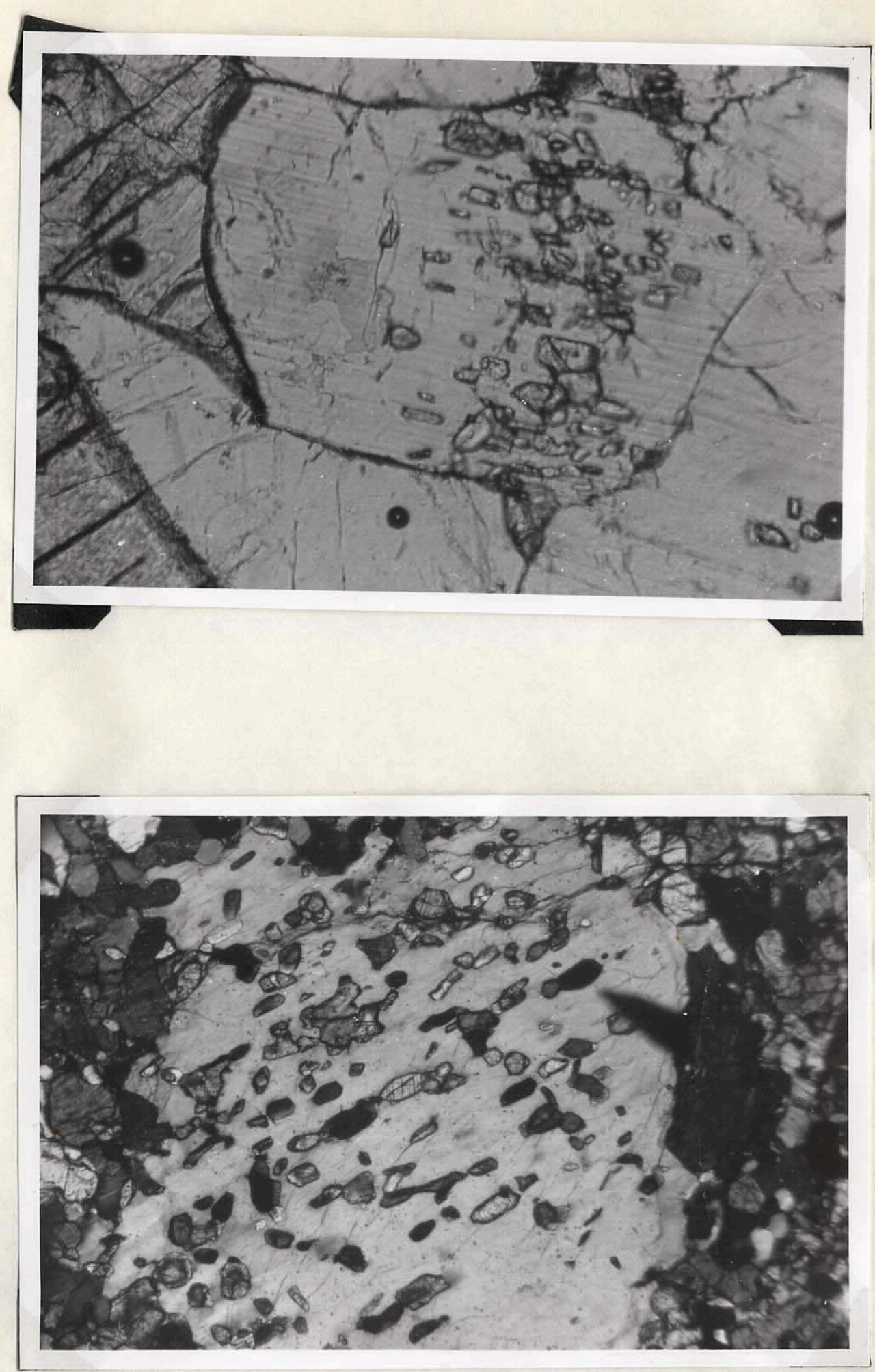


\section{PLATE 17}

Euhedral inclusions in plagioclase, olivine pyroxenite ( $x$ 135).

\section{PLATE 18}

Antipathetic relationship between fine euhedral inclusions in plagioclase and large foreign inclusions (pyroxene) mafic pegmatite (x 50). 

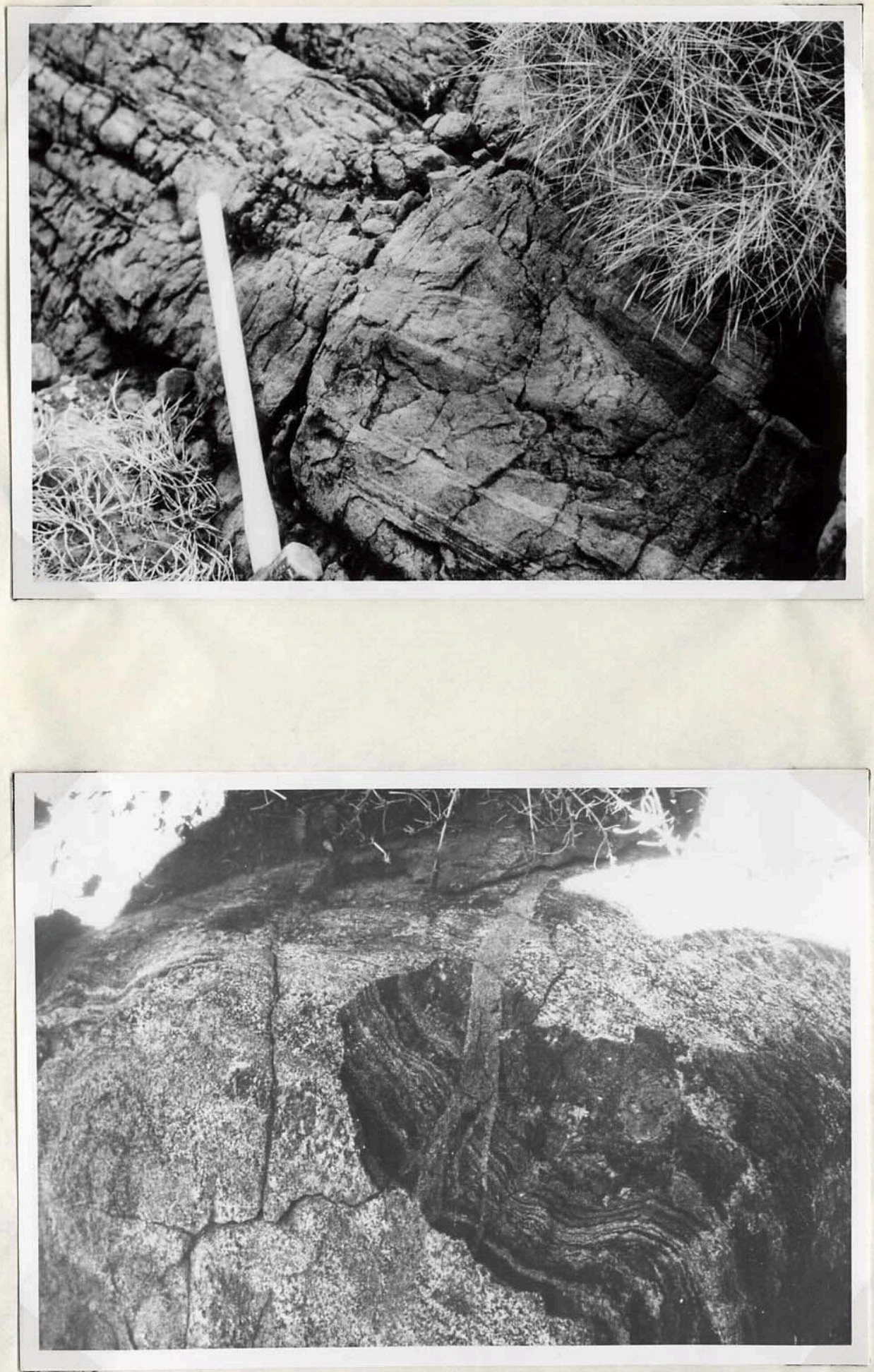


\section{PLATE 19}

Exsolution lamellae in bronzite, olivine pyroxenite $(x$ 135).

PLATE 20

Vermicular spinel of the symplectic intergrowth (Plate 25) "emanating". from spinel euhedra (x 135). 

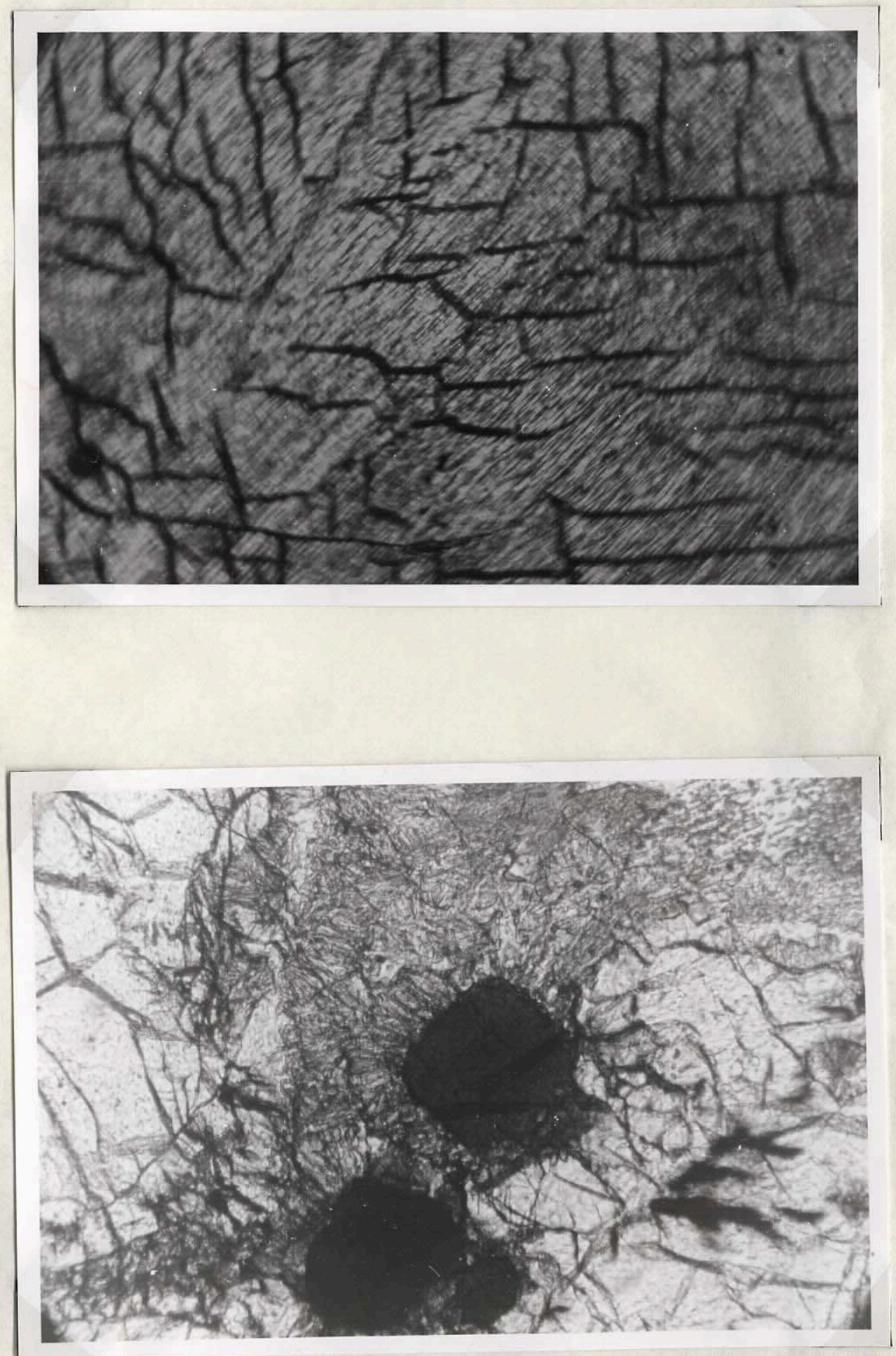


\section{PLATE 21}

Opaque intergrowths in olivine ( $x$ so).

\section{PLATE 22}

Rounded olivine crystals surrounded by bronzite and biotite $(x 50)$ 

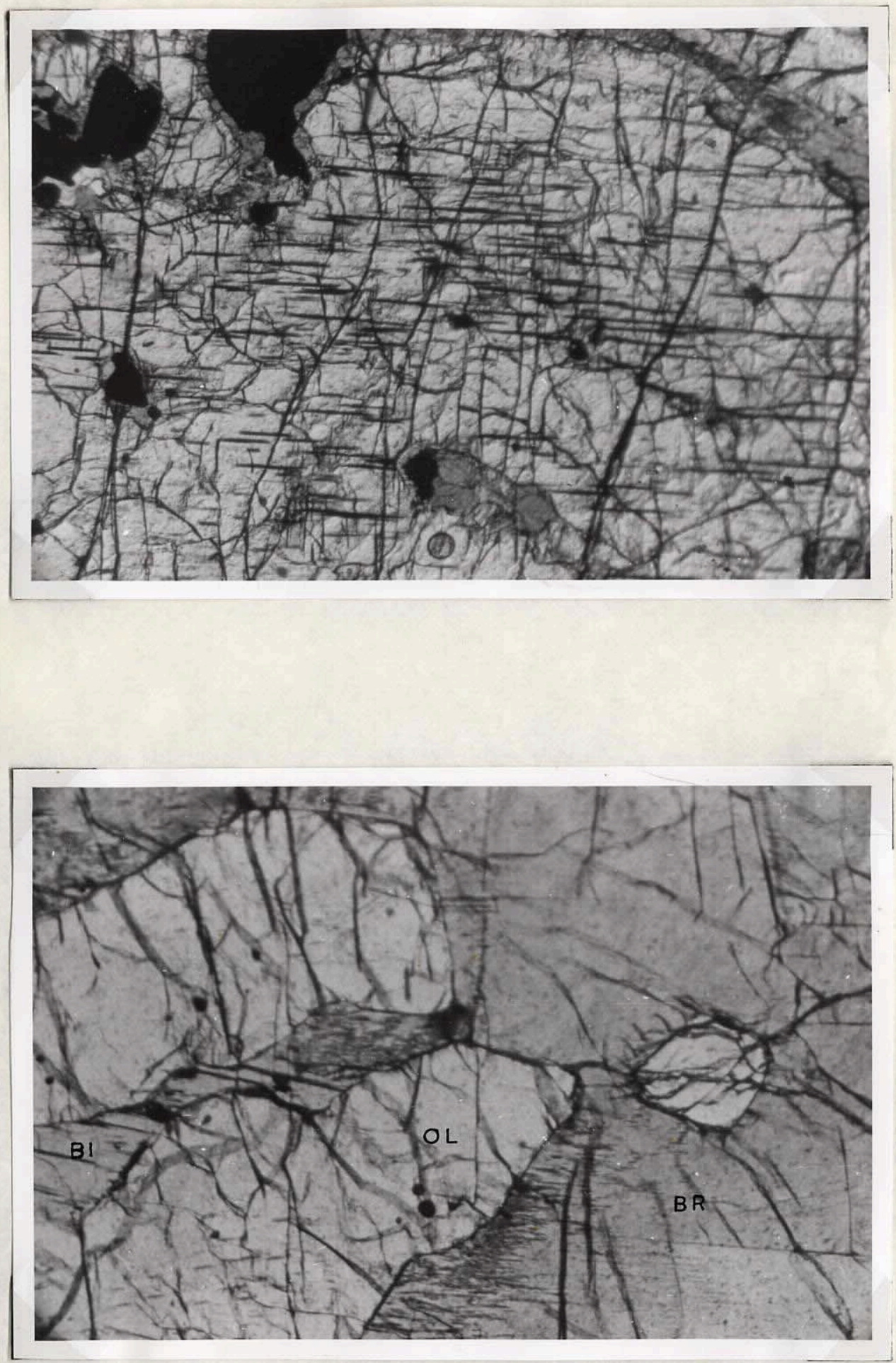


\section{PLATE 23}

Granular pyroxene and plagioclase radial to interface between plagioclase phenocrysts, mafic pegmatite (x 50).

\section{PLATE 24}

Hormblende replacing orthopyroxene, contact zone (x 50). 

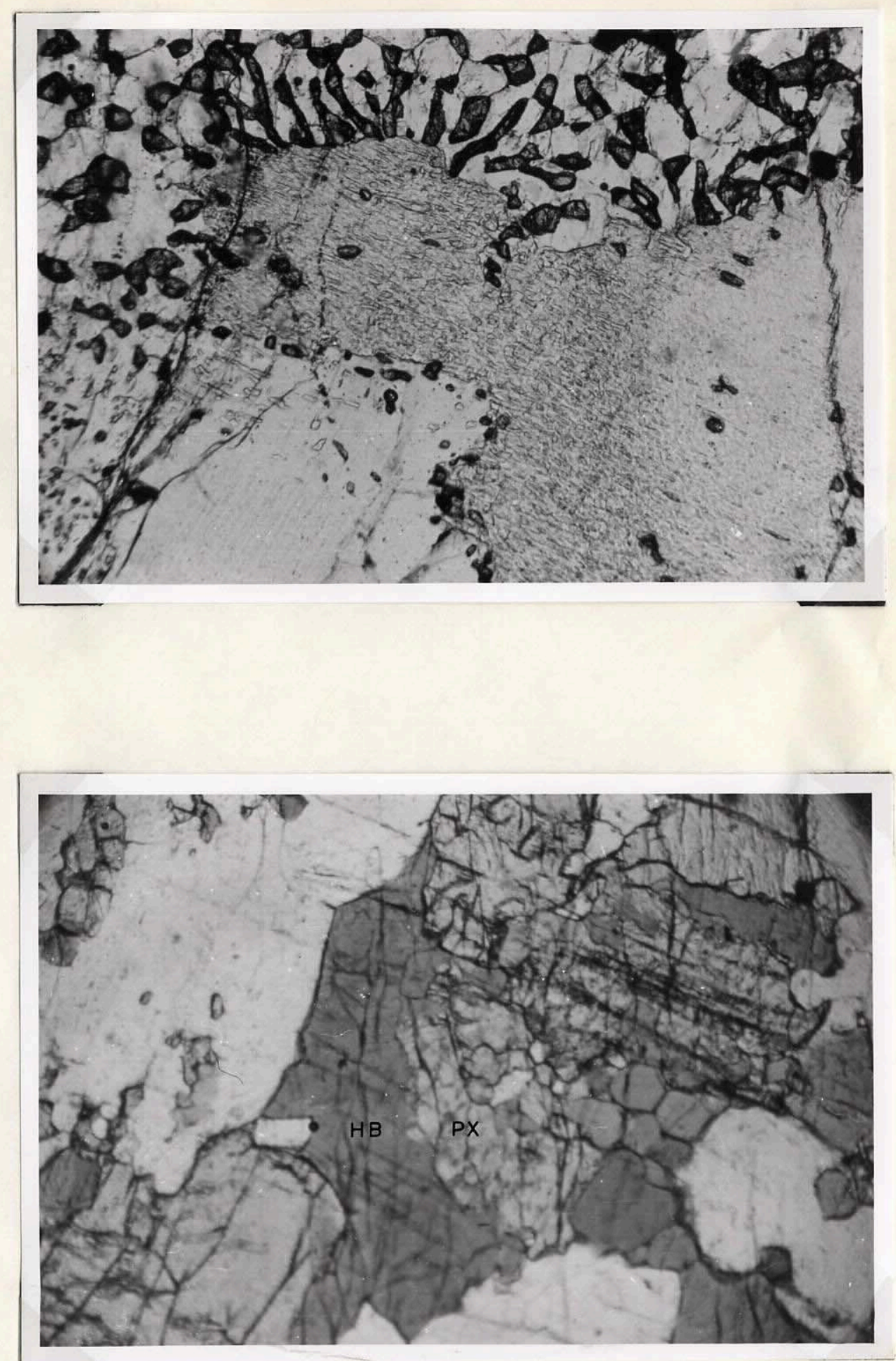


\section{PLATE 25}

Coronal rim of orthopyroxene and a green symplectic intergrowth

(s) between olivine and plagioclase. Olivine also shows dendritic opaque intergrowth ( $x$ 50).

\section{PLATE 26}

Drial rim of a symplectic intergrowth $\left(S_{1}, s_{2}\right)$ between plagioclase and zoned bronzite, olivine pyroxenite (x 135). 

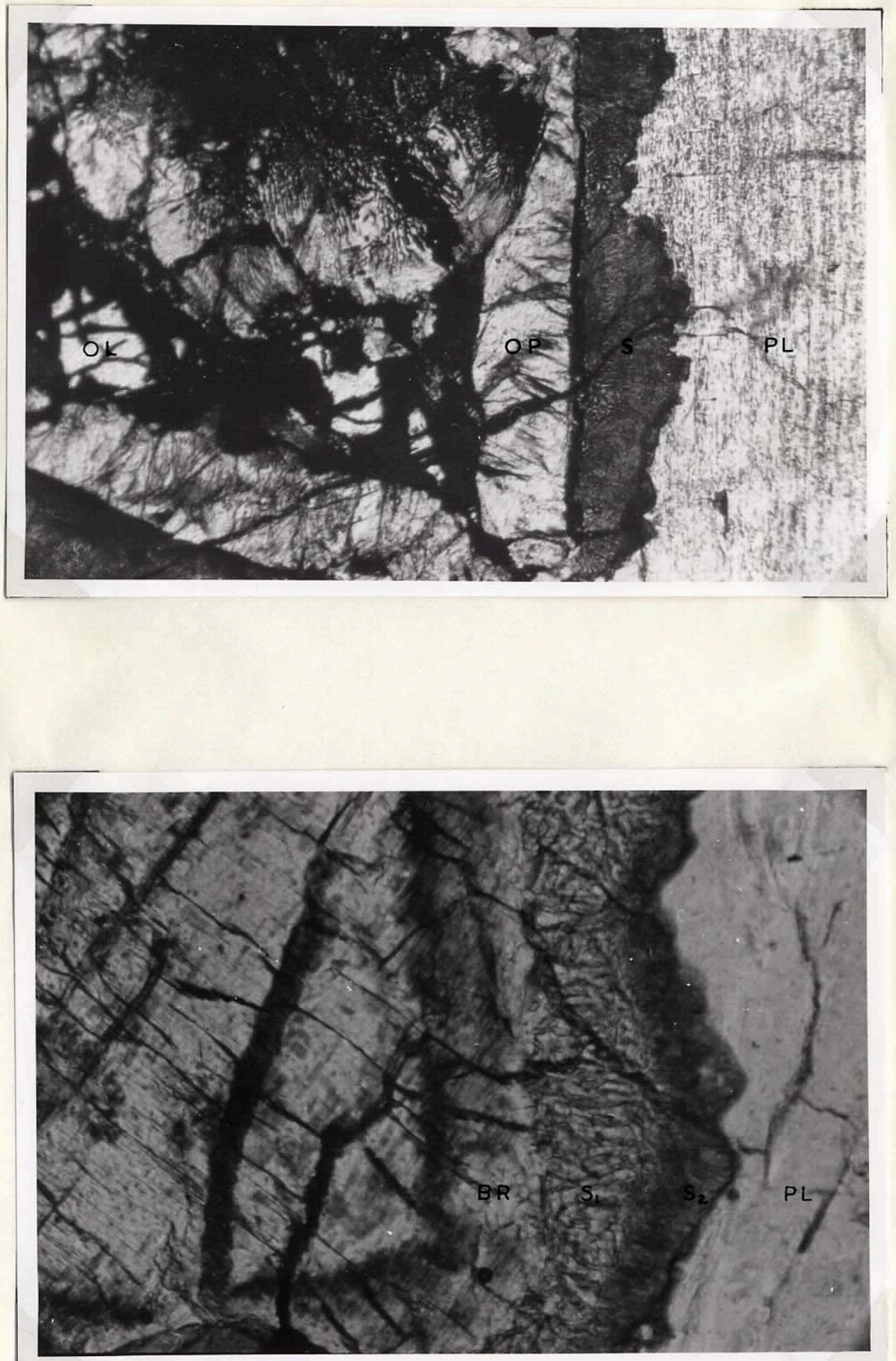


\section{PLATE 27}

Secondary enlargement of bronzite, olivine pyroxenite (x 50).

\section{PLATE 28}

Spinel vermicules growing into secondary bronzite rim (x-135). 

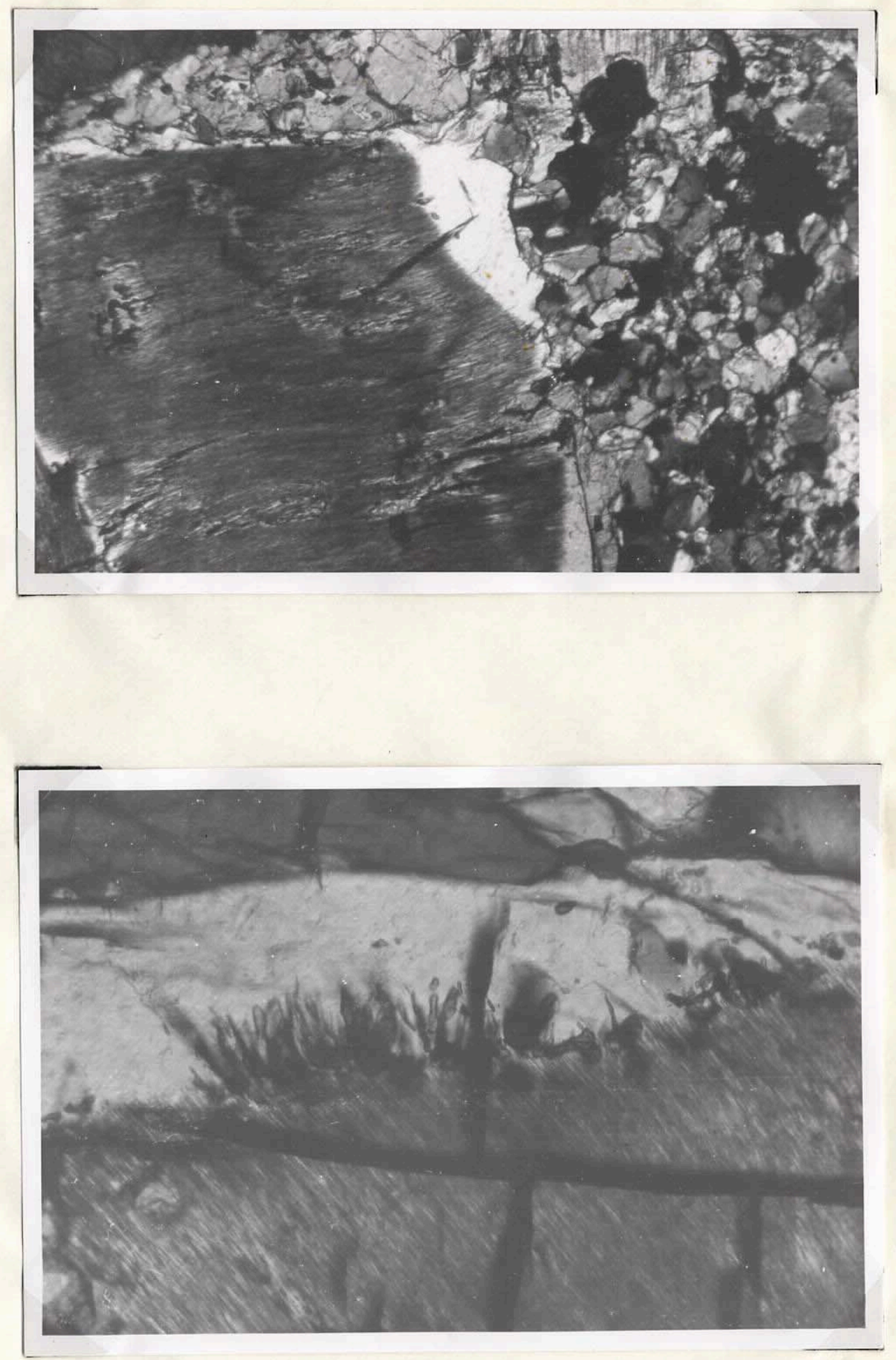


\section{PLATE 29}

Normal zoning $(n)$ and hourglass zoning $(h)$ in bronzite, lower layer (x 50).

PLATE 30

Hourglass zoning, bronzite (x 50). 

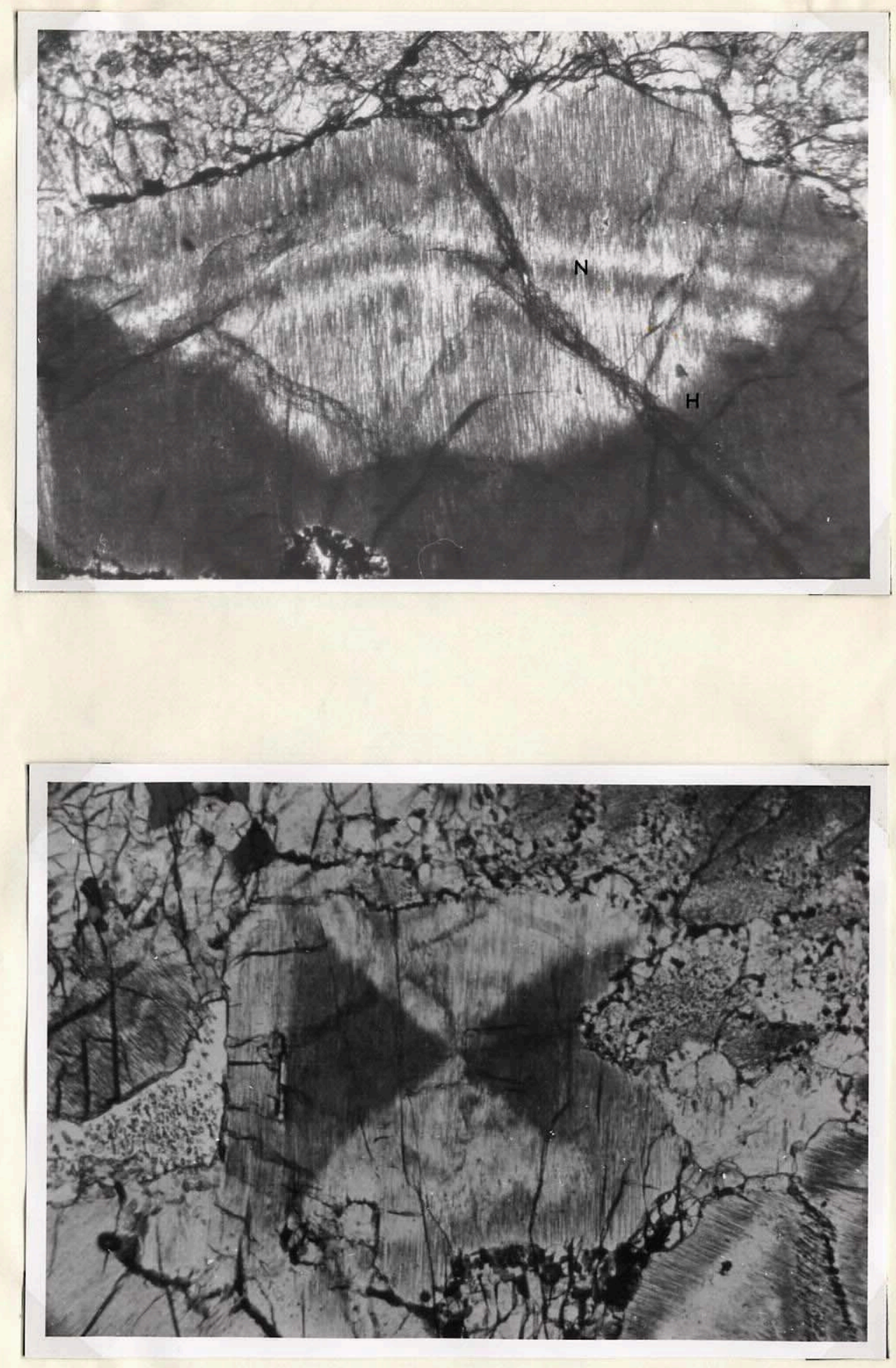
PLATE 31

Kink bands in bronzite (x 50).

\section{PLATE 32}

Kink bands and bent cleavages, bronzite ( $x 50)$. 

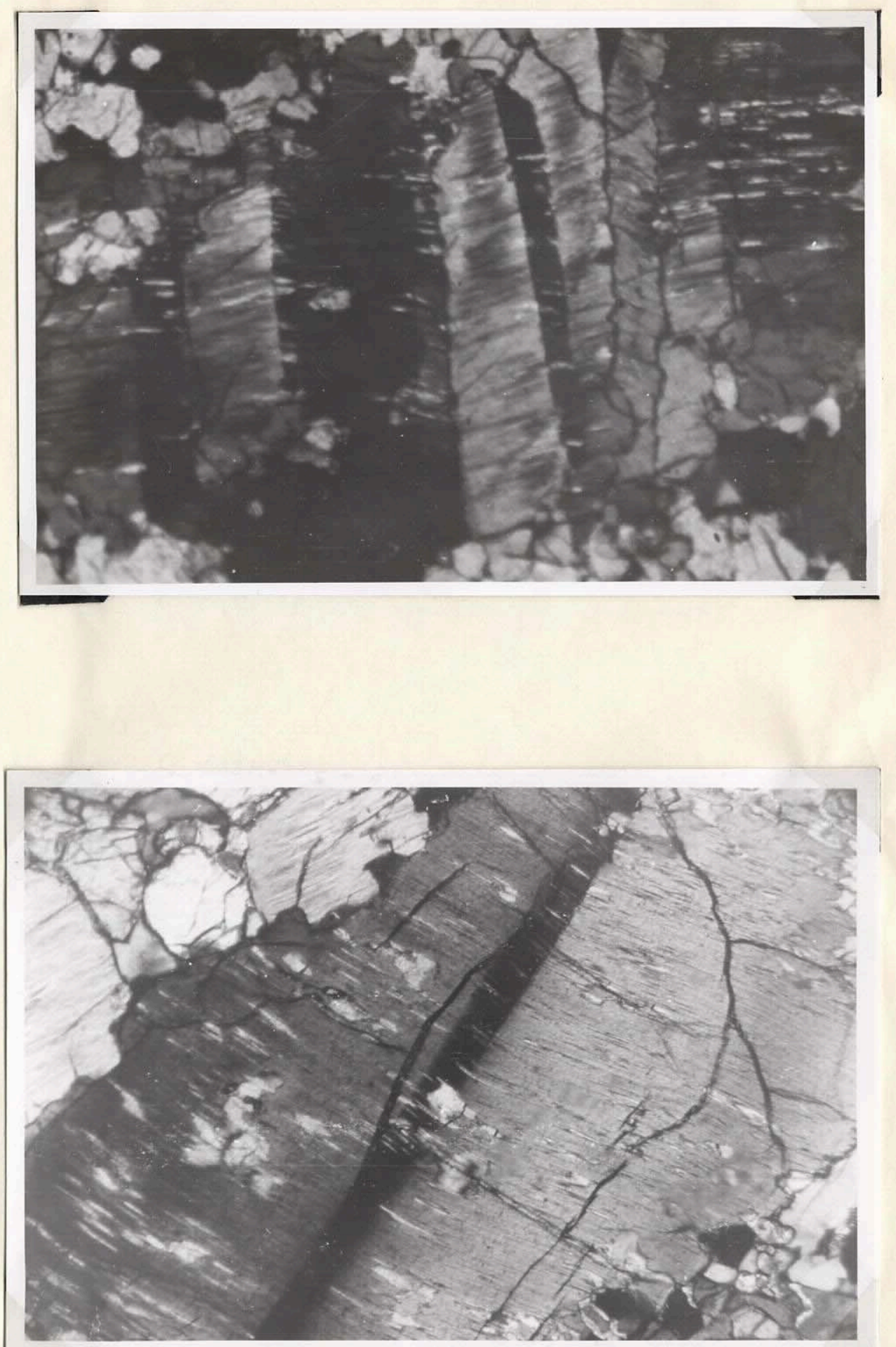


\section{PLATE 33}

Fragmental breakup of bronzite (x 50).

PLATE 34

Undulatory banding, olivine ( $x$ 50). 

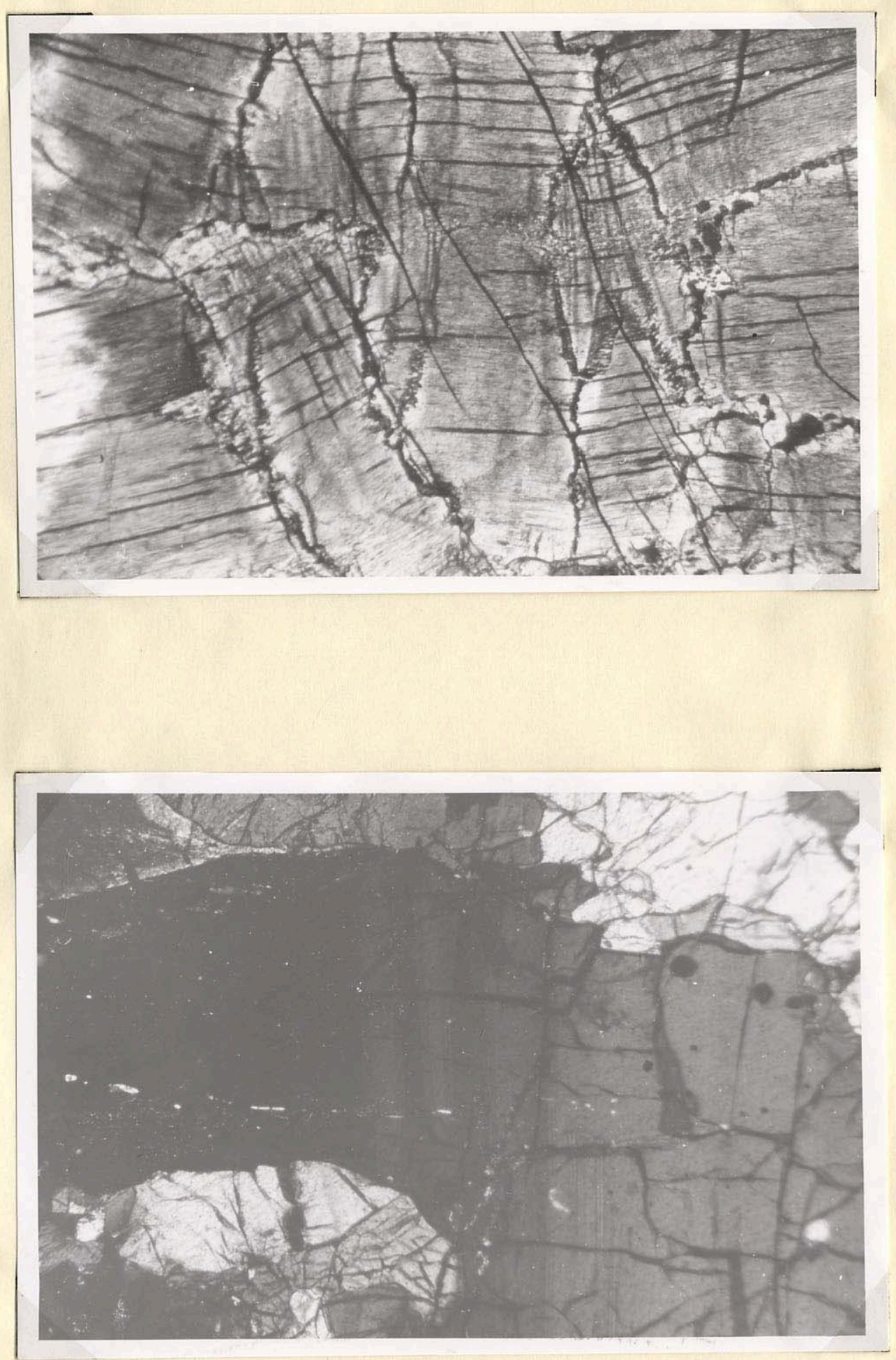


\section{PLATE 35}

Cataclisation of pyroxene in situ (x 50).

\section{PLATE 36}

Fingerprint texture, pyroxene (x 50). 

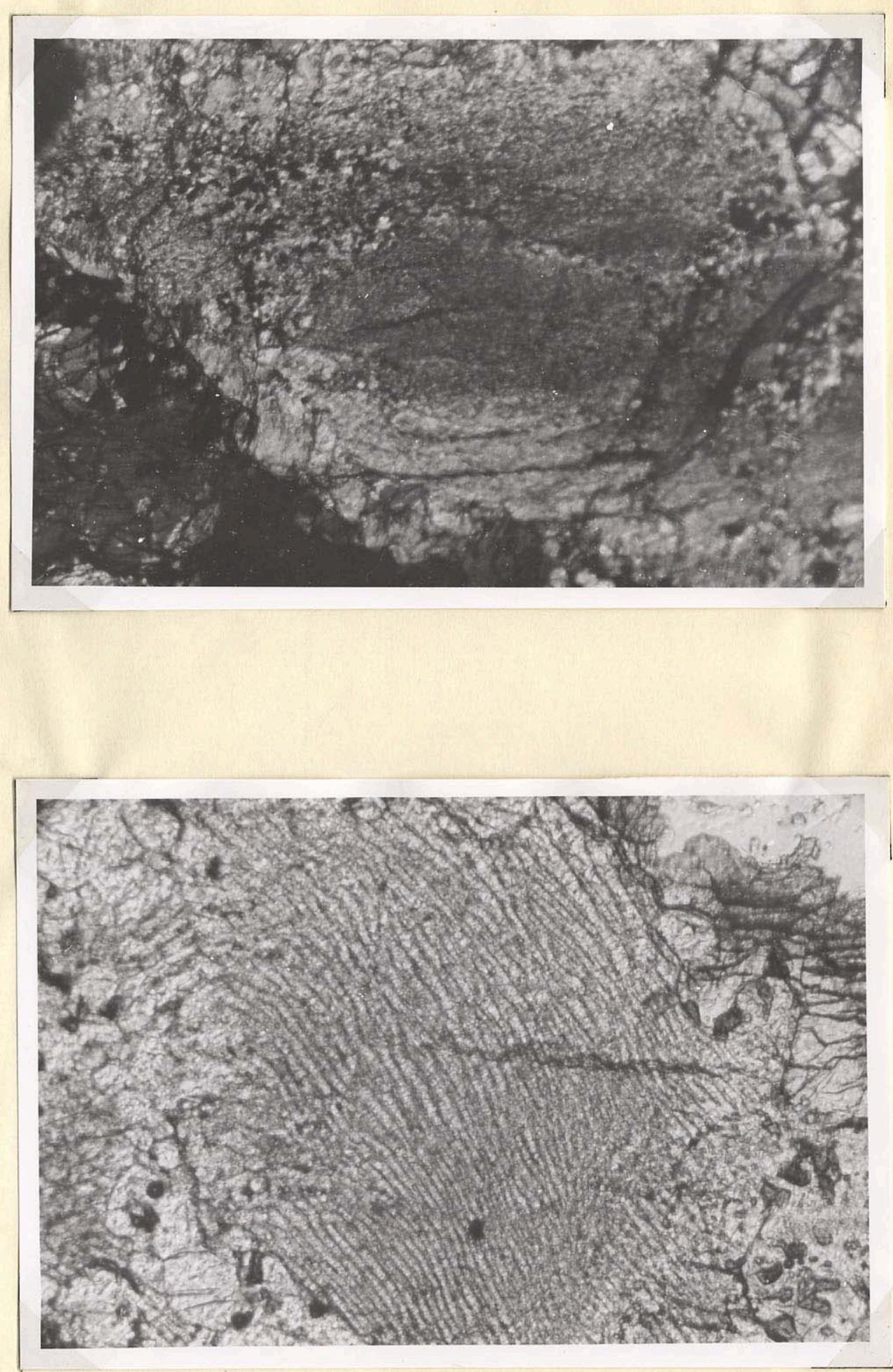
PLATE 37

Homblende rimming pyroxene and opaques, Plagioclase also present (x 50).

PLATE 38

Intergrowths in core of garnet from black granulite ( $x$ 135). 

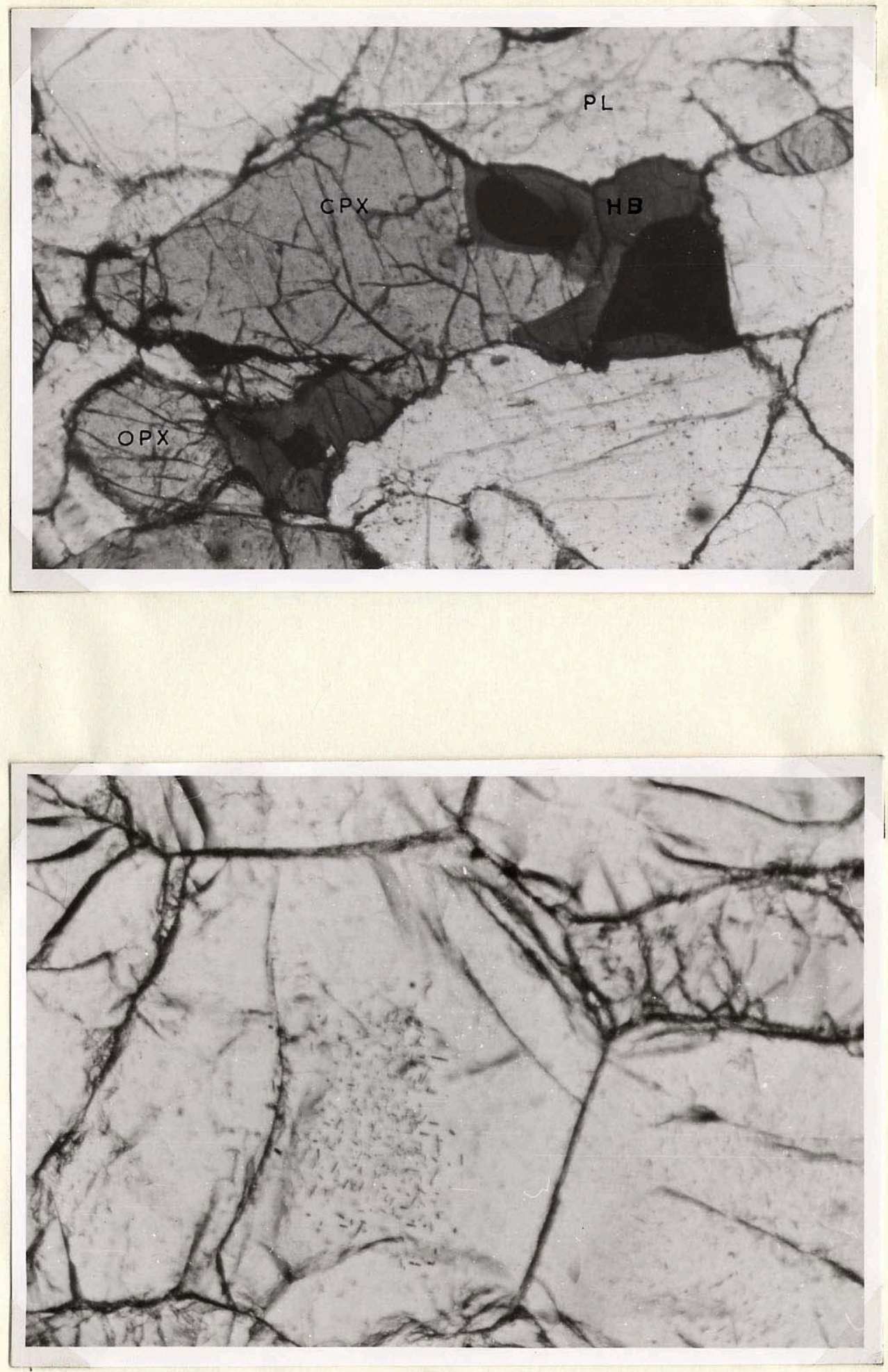
PLATE 39

Association of plagioclase, or thopyroxene, symplectic garnet and opaques from augen gneiss ( $x$ 50).

\section{PLATE 40}

Garmet with dactylitic quartz (?) inclusions, from augen gneiss (x.50). 

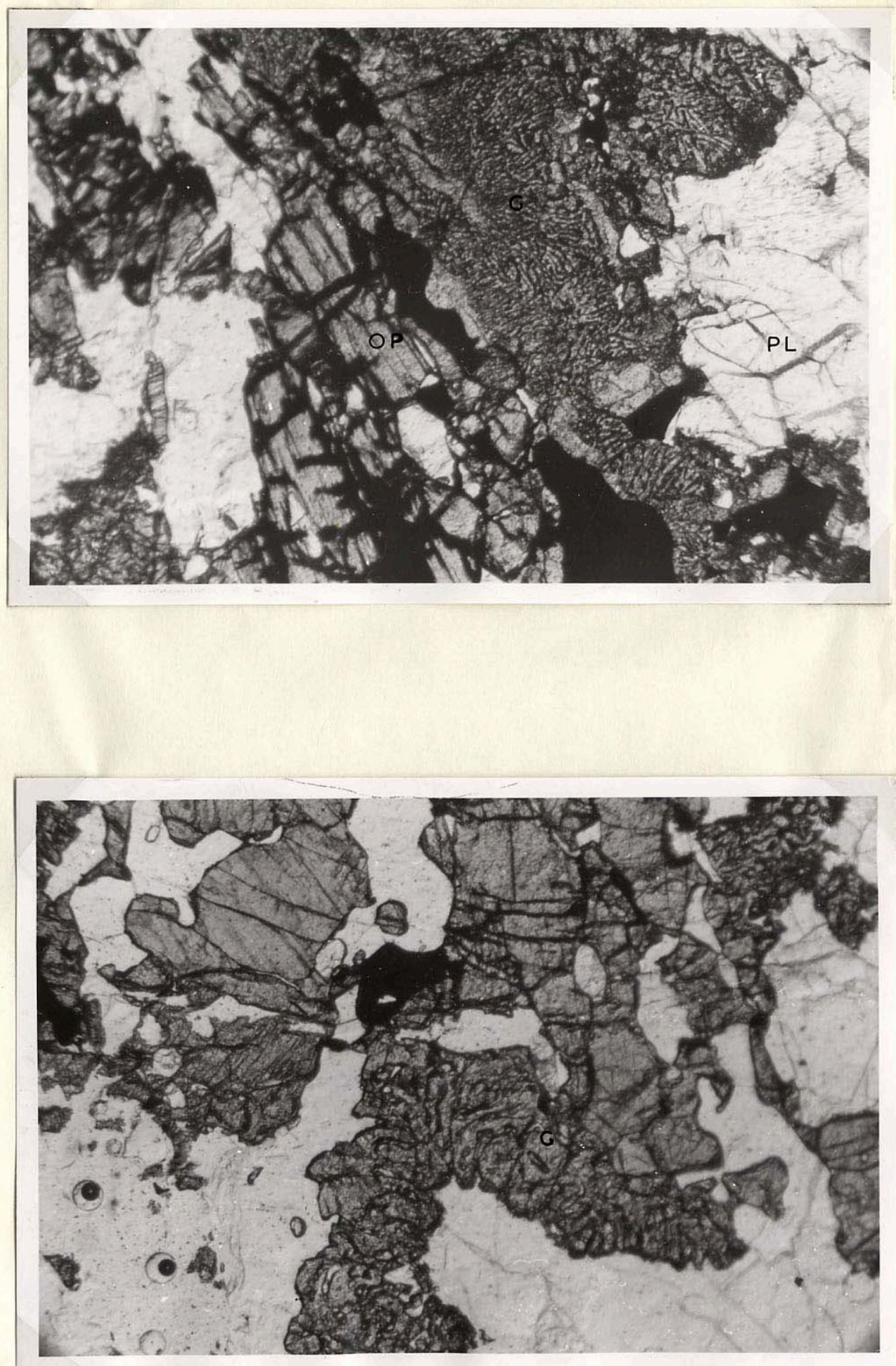
PLATE 41

Unknown aggregate in core of istotropic "clumps", dolerite dyke. Pyroxene shows sheaf kinking ( $x$ 50).

\section{PLATE 42}

Isotropic clump, dolerite dyke (x 50). 

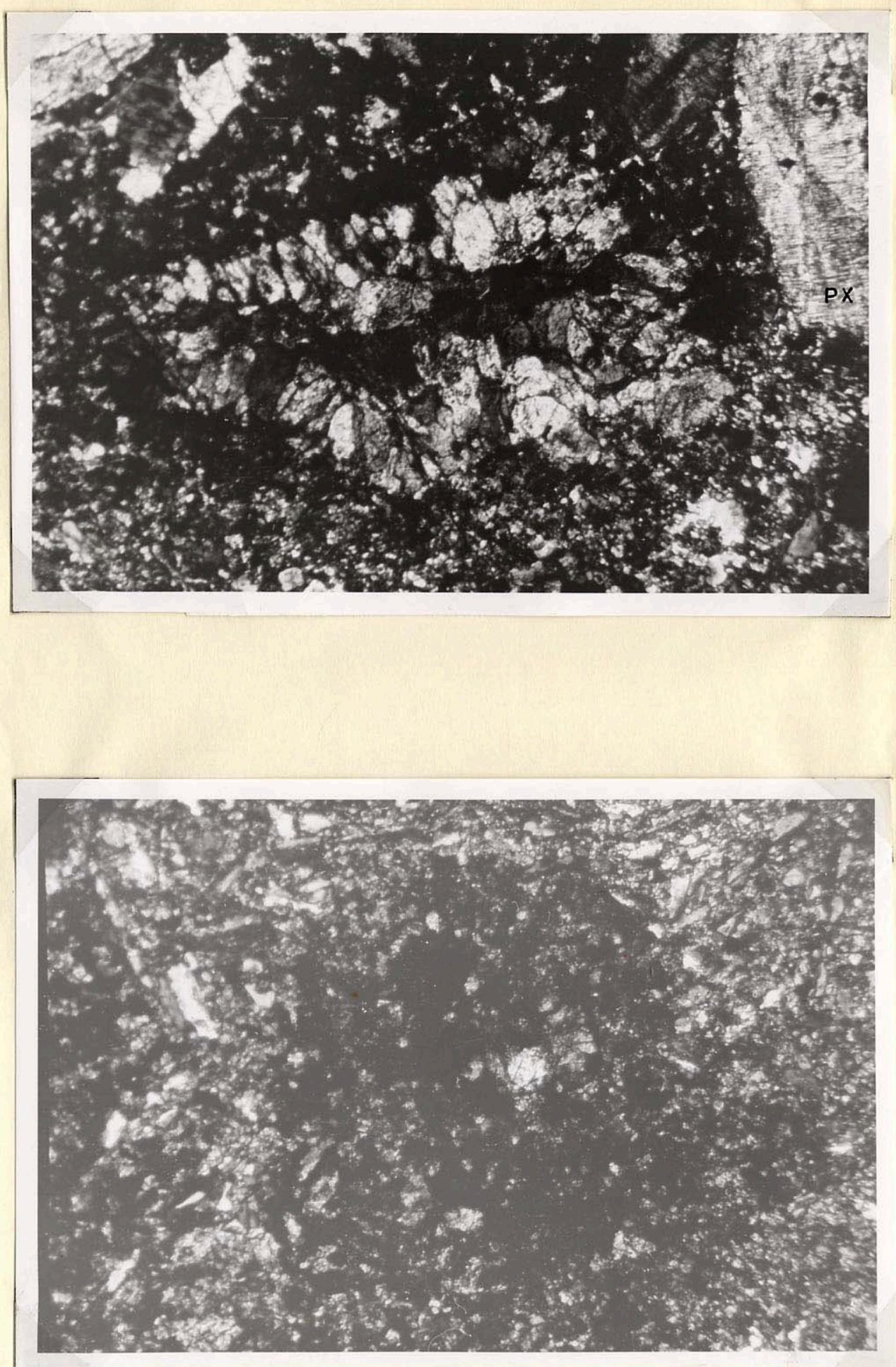


\section{PLATE 43}

- Granulated "flow" texture in anorthosite. Plagioclase phenocryst shows outer zone of antiperthite (a) and inner zone of fine needles ( $n)$ (x 50). 


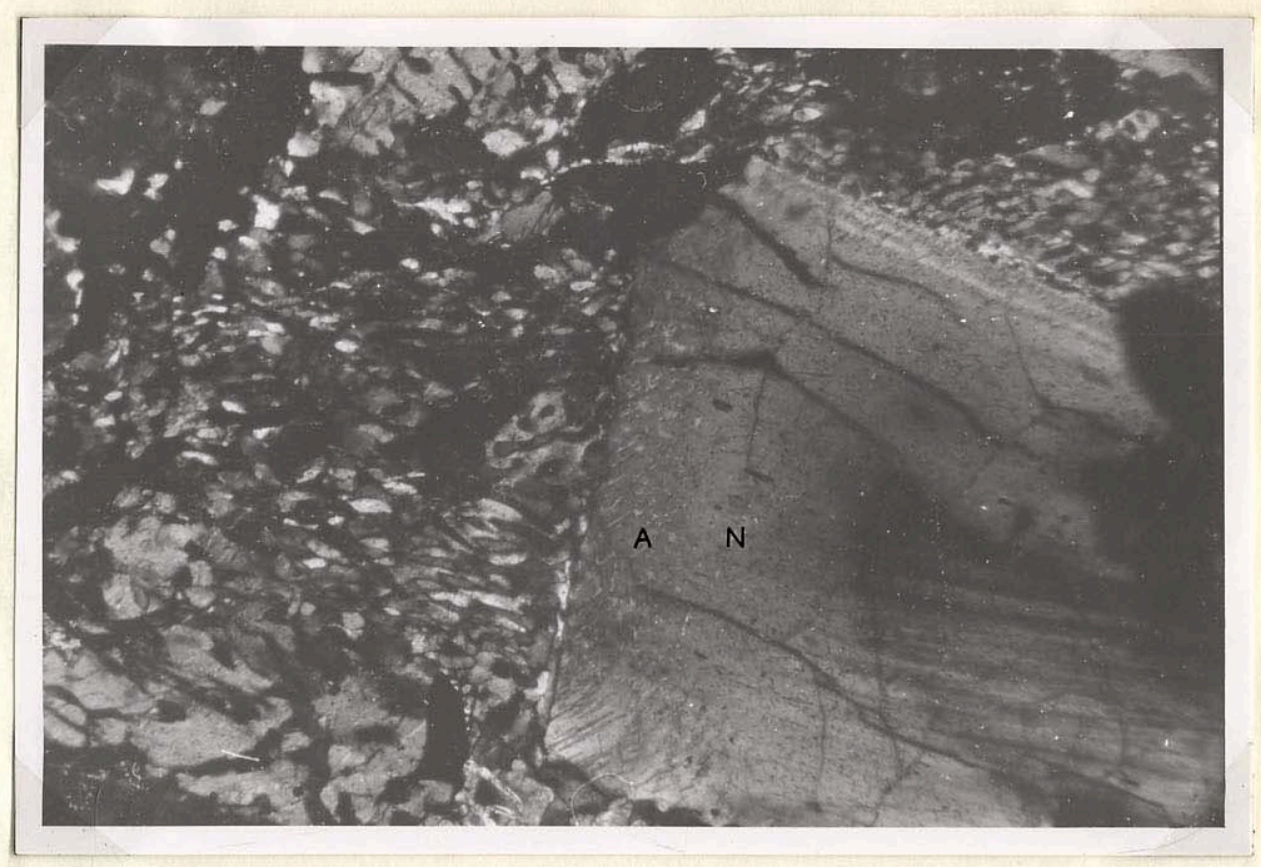




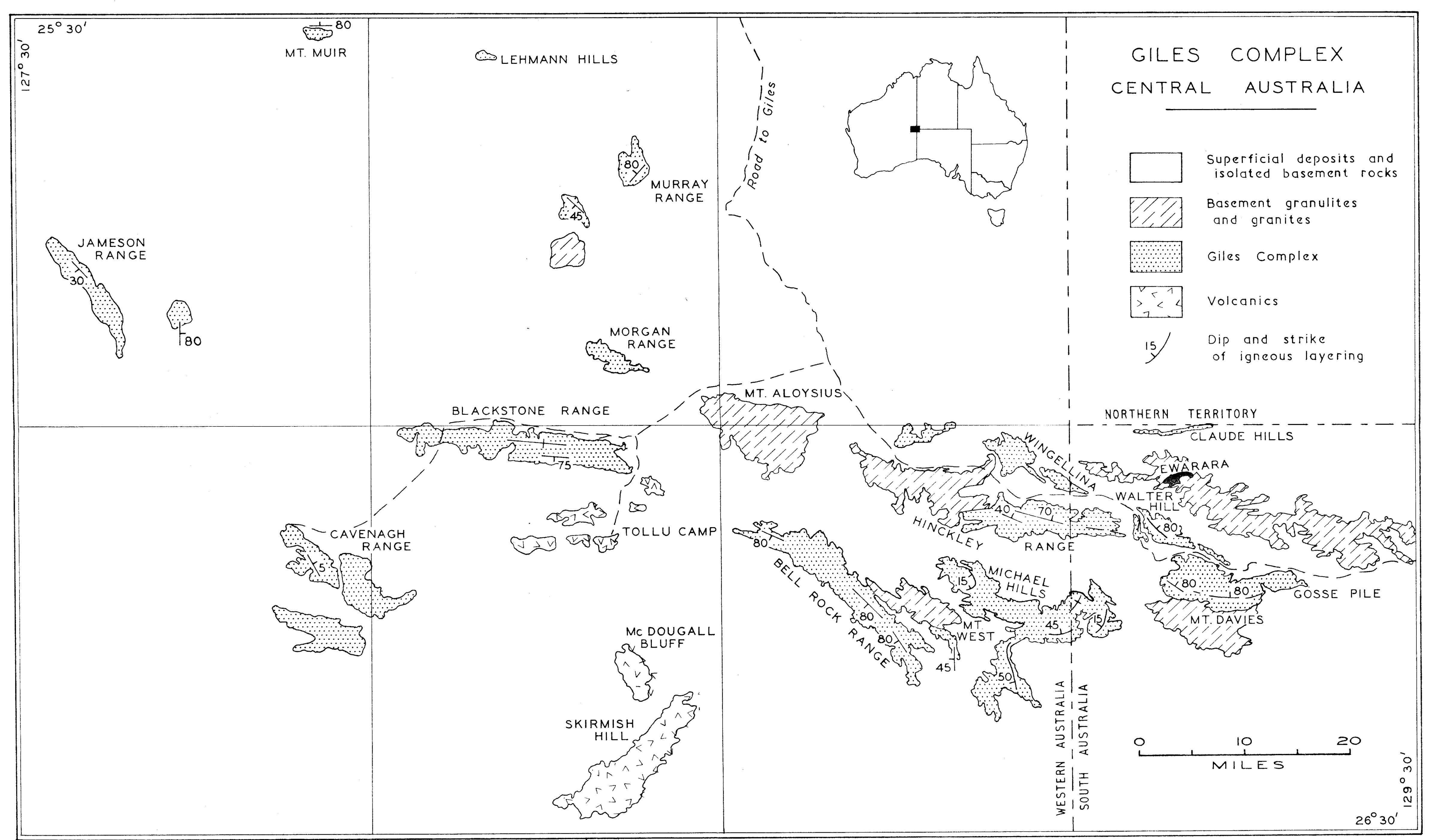




\section{GEOLOGY OF EWARARA INTRUSION}

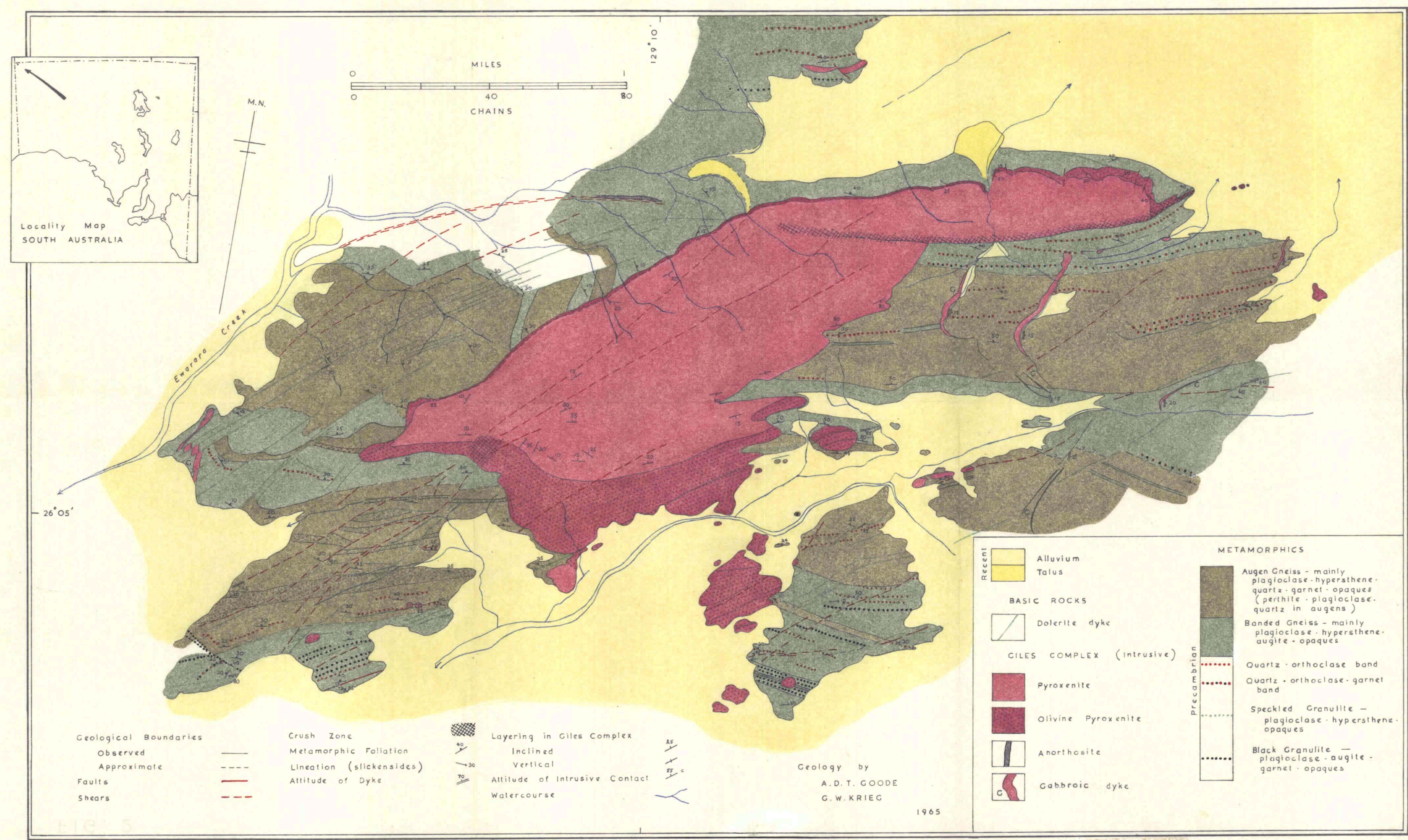




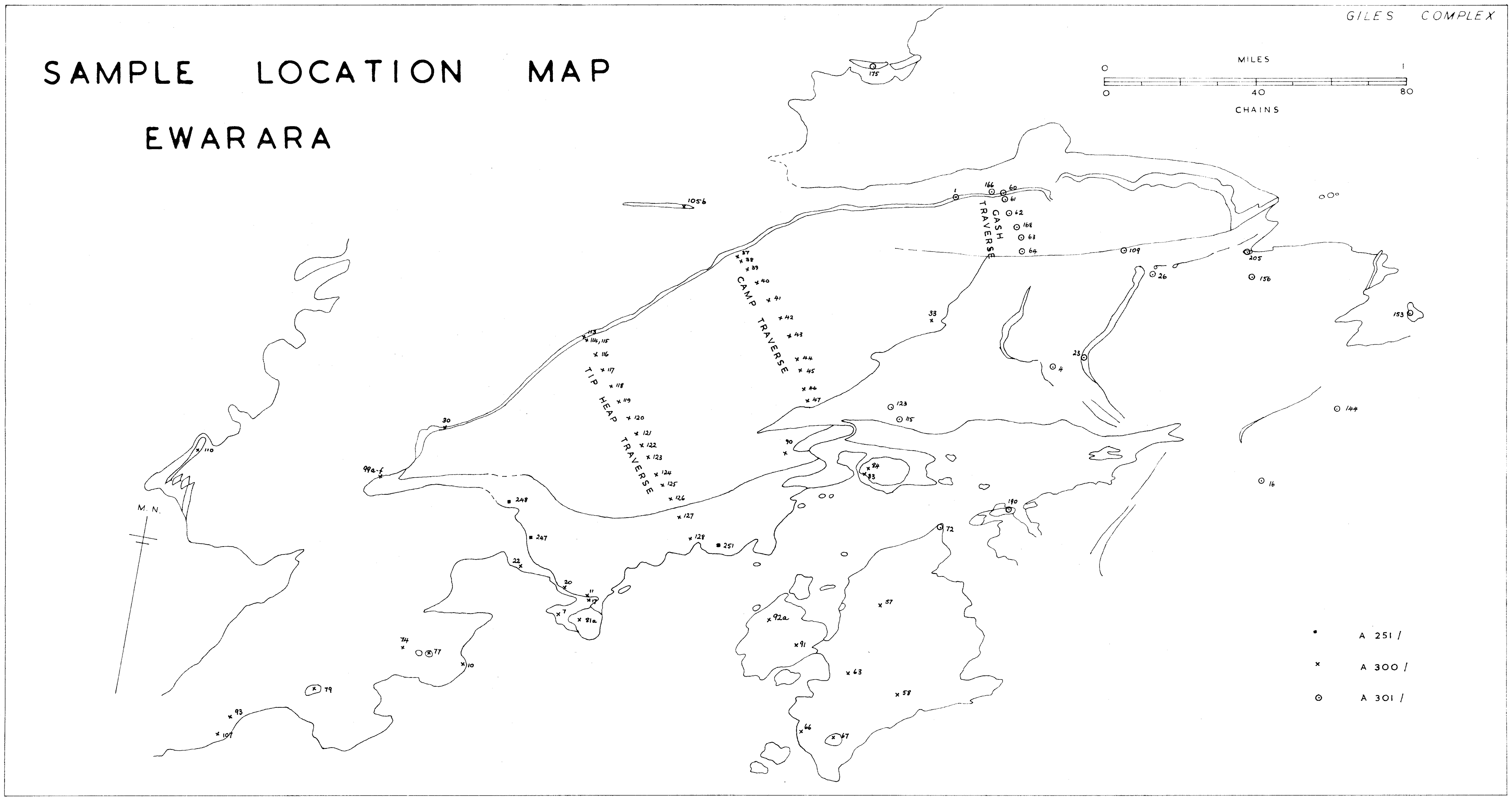

